\title{
AMPHIBIOUS ARCHITECTURE LIVING WITH A RISING BAY
}

\author{
A Thesis \\ presented to \\ the Faculty of California Polytechnic State University, \\ San Luis Obispo \\ In Partial Fulfillment \\ of the Requirements for the Degree \\ Master of Science in Architecture \\ by \\ Heather Christine Anderson \\ June 2014
}


(C) 2014

Heather Christine Anderson

ALL RIGHTS RESERVED

Page ii 


\section{COMMITTEE MEMBERSHIP}

TITLE:

AUTHOR:

DATE SUBMITTED:

COMMITTEE CHAIR:

COMMITTEE MEMBER:

COMMITTEE MEMBER
Amphibious Architecture : Living with a Rising Bay

Heather Christine Anderson

June 2014

Thomas Fowler, M.Arch., Assistant Department Head Architecture Department

Kevin Dong, M.S., Professor

Architectural Engineering Department

Umut Toker, Ph.D, Associate Professor City and Regional Planning Department 


\section{ABSTRACT \\ Amphibious Architecture : Living with a Rising Bay}

Heather Christine Anderson

Over the past century, sea level has risen nearly eight inches along the California coast and climate scientists suggest substantial increases in sea level as a significant impact of climate change over the coming century. This project explores the concept of creating a sustainable living environment for seaside residents in Redwood City as an alternative to permanent construction on land in the event of a substantial rise in sea level.

This project will generate a flood-resilient design solution that is capable of rising and falling with the water. In order to ensure the well-being of the inhabitants, I will analyze a number of case studies, notably the Netherland's water dwellings, New Orleans's amphibious residences and Sausalito's floating communities, for the purpose of identifying key themes that will facilitate the construction of a single-family amphibious residence in Redwood City.

This project is a response to environmental design challenges raised by ongoing atmospheric events such as the gradual rise in sea level and disastrous events such as Hurricane Katrina in 2005 where extreme flooding due to failed coastal defenses exhibited catastrophic effects on coastal residences, its inhabitants, and the surrounding ecosystem. 
TABLE OF CONTENTS

List of Tables ................................................................... viii

List of Figures ............................................................... ix

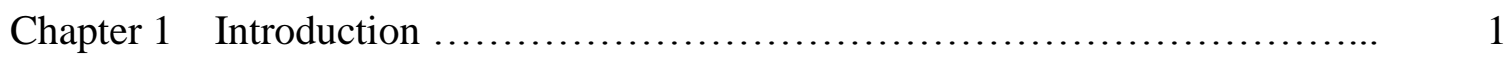

1.1 Introduction 1

Chapter 2 Climate Change \&Water Dwelling Typologies ...................... 3

2.1 Reality of Climate Change 3

2.2 Why Live on Water? 5

2.2.1 Urban Congestion 5

2.2.2 Proven Mitigation Method 6

2.2.3 Cost 6

2.3 Water Dwelling Typologies $\quad 7$

2.3.1 Terp Dwellings $\quad 7$

2.3.2 Static Elevation $\quad 8$

2.3.3 Pile Dwellings 9

2.3.4 Houseboats 10

2.3.5 Amphibious Dwellings 11

2.4 Summary of Water Dwelling Typologies 13

Chapter 3 Precedent Studies .............................................. 15

3.1 Introduction $\quad 15$

3.2 Sausalito Bay, California 15

3.3 New Orleans 18

3.3.1 Buoyant Foundation Project 20

3.3.2 FLOAT House $\quad 24$

3.4 Netherlands 27

3.4.1 Maasbommel Waterdwellings 29

3.4.2 Waterdwellings IJburg 32

Page v 
3.5 Summary of Precedent Studies 36

Chapter 4 Project Location ............................................. 38

4.1 Redwood City, CA 38

4.2 Existing Land Use $\quad 38$

4.3 Population Trends and Housing 39

4.4 Historical Flooding and Mitigation Efforts $\quad 40$

4.5 Site Location : Redwood City's Urban Reserve Salt Ponds 43

4.6 History of the Salt Ponds 44

4.7 Salt Pond Levee System $\quad 45$

4.8 Tides in Redwood City 46

4.9 Restoring Additional Salt Ponds 51

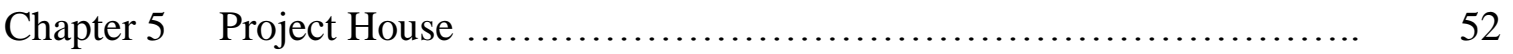

5.1 House Goals

5.2 House Concept 53

5.3 Conceptual Ideation of Building 54

5.4 Project Description 55

5.5 Architectural Plans 61

5.6 Architectural Sections \& Details 64

5.7 Concrete Foundation and Piles $\quad 69$

$\begin{array}{ll}5.8 \text { Roads and Parking } & 70\end{array}$

5.9 Pedestrian Walkways $\quad 70$

5.10 Entrance Ramp 72

5.11 Cables and Pipes $\quad 72$

5.12 Fire Security 73

5.13 Underwater Maintenance 73

5.14 Floating Calculations $\quad 74$

5.14.1 Determining Dead Load 75

5.14.2 Determining Live Load 77 
5.14.3 Determining the Area of the Floating Body 77

5.14.4 Density of Water 77

5.14.5 Calculating Buoyancy $\quad 78$

5.15 Cost Estimate $\quad 78$

Chapter 6 Recommendations for a New Amphibious Community .............. 80

$\begin{array}{ll}6.1 \text { Planning } & 80\end{array}$

$\begin{array}{ll}6.2 \text { Policies } & 81\end{array}$

6.3 Sustainable Construction Practices and Policies $\quad 81$

6.4 Regulatory Requirements $\quad 82$

6.5 Determining Land Use $\quad 83$

6.6 Design 84

6.7 Construction and Financing $\quad 84$

6.8 Re-purposing the Levees $\quad 85$

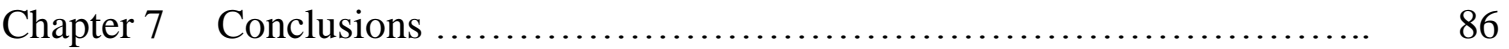

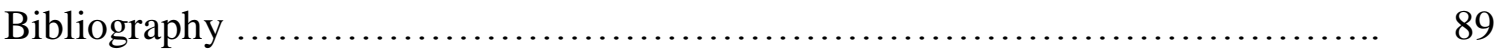




\section{LIST OF TABLES}

Table 1 Advantages \& Disadvantages of Water Dwelling Typologies 13

Table 2 Summary of Precedent Studies 36

Table 3 Cargill Salt Pond Tidal Benchmarks 47

Table 4 Load Values for Materials 76

Table 5 Density Values for Materials 76 


\section{LIST OF FIGURES}

Fig. 1 Predicted Sea Level Rise in San Francisco in 2100

Fig. 2 Terp Dwelling 7

$\begin{array}{lll}\text { Fig. } 3 \text { Static Elevation } & 8\end{array}$

Fig. 4 Timber Pile Residence 9

Fig. 5 Steel Pile Residence 10

Fig. 6 Houseboat Residence 10

Fig. 7 Amphibious Residence 11

Fig. 8 Sausalito Houseboat Community 15

Fig. 9 Barge Houseboat 16

Fig. 10 Houseboat Floor Plan \& Section Drawing 17

Fig. 11 Flooded Houses in New Orleans 19

Fig. 12 House with Buoyant Foundation 20

Fig. 13 Buoyant Foundation Materials 21

Fig. 14 BFP Floor Plan \& Section 22

Fig. 15 FLOAT House 24

Fig. 16 FLOAT House 24

Fig. 17 FLOAT House Floor Plan \& Section 25

Fig. 18 Maeslannt Barrier 28

Fig. 19 Maasbommel Waterdwellings 29

Fig. 20 Maasbommel Community 30

Fig. 21 Maasbommel Floor Plan \& Section 31

Fig. 22 Waterdwellings Ijburg 32

Fig. 23 Ijburg Residence 33

Fig. 24 Ijburg Floor Plan \& Section 34

Fig. 25 Ijburg Residence on Boardwalk 35

Fig. 26 Map of Redwood City 38

Fig. 27 Site Location in Cargill Salt Ponds 43

Fig. 28 Map of Cargill Salt Ponds 45 
Fig. 29 High \& Low Tides in 2013

Fig. 30 Predicted High \& Low Tides in 2014

Fig. 31 Predicted Sea Level Rise in Redwood City in 2100

Fig. 32100 year Flood Level 50

Fig. 33 Predicted High \& Low Tide Levels in 2100

Fig. 34 Map of Predicted Inundation in Cargill Salt Ponds in 2100

Fig. 35 Recessed Mass 53

Fig. 36 Protruding Mass 53

Fig. 37 Varying Window Types 53

Fig. 38 Conceptual Ideation of Building 54

Fig. 39 Exterior Perspective 55

Fig. 40 Exterior Perspective 56

Fig. 41 Exterior Perspective 56

Fig. 42 Dining \& Kitchen Perspective 57

Fig. 43 Living Room \& Kitchen Perspective 57

Fig. 44 Bedroom Perspective 58

Fig. 45 Interior Hallway Perspective 59

$\begin{array}{lll}\text { Fig. } 46 & \text { Exterior Perspective } & 60\end{array}$

Fig. 47 Exterior Perspective $\quad 60$

Fig. 48 First \& Second Floor Architectural Plans 61

Fig. 49 First \& Second Floor Dimensioned Plans 62

Fig. 50 Exploded Axonometric Plans 63

$\begin{array}{lll}\text { Fig. } 51 & \text { Section A \& B } & 64\end{array}$

$\begin{array}{lll}\text { Fig. } 52 \text { Detail } 1 & 65\end{array}$

Fig. 53 Section C, Detail $2 \& 3$

Fig. 54 Section D \& E, Detail 4 \& 5

$\begin{array}{lll}\text { Fig. } 55 & \text { Section F \& Detail } 6 & 68\end{array}$

Fig. 56 Levee Infrastructure \& Section G 71

$\begin{array}{lll}\text { Fig. } 57 & \text { Detail } 7 & 72\end{array}$ 


\section{Chapter 1}

\section{Introduction}

\subsection{Introduction}

Humans rely on heavy engineering, tidal barriers and riverside and coastal defenses to protect our built environment from flooding. The desire to live adjacent to water reflects our cultural heritage and historic settlement patterns, and we continue to build on flood plains and other flooding-prone areas. However, coastal defenses, such as the river barriers in the Netherlands and the levee system in New Orleans, have proven ineffective when it comes to a drastic rise in sea level. The Federal Emergency Management Agency (FEMA) predicts a 16-inch rise in sea level by midcentury and a 55-inch rise in sea level by the end of the century in the San Francisco Bay. A 16-inch rise would potentially expose 281 square miles of Bay shoreline to flooding, and a 55inch rise would potentially expose 333 square miles to flooding. If no adaptation measures are taken, a 55-inch rise in sea level will place an estimated 270,000 people in the Bay Area at risk from flooding. Residents, businesses and entire industries that currently thrive on the shoreline will be at risk of flooding by the middle of the century if nothing is done to protect, elevate or relocate them. In order to defend our communities against rising sea levels and flooding, long-term approaches to building design must be considered that will provide alternative dwelling opportunities for coastal residents.

As much as $90 \%$ of the 100 largest cities in the world are located on water. Furthermore, these cities have a substantial amount of water in the city itself, in the form of lakes, rivers, canals, harbors, bays or open oceans. The high complexity of the modern 
city requires a high level of flexibility so that changing special requirements can find a place within the existing structures. Flexibility can include fitting in a considerable amount of open space, or space that has low economic value, such as building on water.

This project will develop an appropriate design solution for an amphibious house in the Redwood City urban reserve in response to the gradual rise in sea level that is predicted by FEMA. Solutions will include waterproof materials and the protection of vital utilities, a barge that acts as the buoyant foundation, and vertical guidance poles attached to the barge that provide resistance to lateral forces from wind and water. The development of an amphibious community is a long-term mitigation strategy that will minimize the potential risk of flooding in coastal residences while maintaining public health and wellbeing. 


\section{Chapter 2}

\section{Climate Change \&Water Dwelling Typologies}

\subsection{Reality of Climate Change}

California's coastline, which includes more than 2,000 miles of open coast and enclosed bays, is vulnerable to a range of natural hazards, including storms, extreme high tides, and rising sea levels resulting from global climate change. Greenhouse gases, including carbon dioxide and methane, are causing an overall warming of the planet, commonly referred to as global warming. The term climate change describes the variable consequences of global warming over time. (Climate Action Plan for San Francisco, 14) In January of 2001, the United Nation's Intergovernmental Panel on Climate Change (IPCC) reviewed years of scientific research on climate change in order to understand the present reality of climate change and the future situation. The research conducted by the IPCC found that the average temperature of the globe increased by $1.5^{\circ} \mathrm{F}$ in the past 100 years. This change in the natural world has been linked to a number of environmental impacts, including a decrease in snow-cover, arctic ice thinning by $40 \%$, and global sea level rise of 4-8 inches during the last century. Leading scientists around the world agree that climate change is a reality and that human activities are intensifying the greenhouse effect.

A study on sea level rise and greenhouse gas emissions was conducted by the California Climate Change Center to determine the risks associated with coastal communities in California. Figure 1 is a map generated by the Bay Conservation and Development Commission that depicts the areas that will be inundated in the San Francisco bay within the next 100 years. The study included a detailed analysis of the 
current population, infrastructure, and property risk from the projected sea level rise. The following findings from the California Climate Change Center are summarized as follows:

1. The mean sea level rise along the California coast is projected to rise from 1.0 to 1.4 meters by the year 2100 .

2. A 1.4 meter sea level rise will

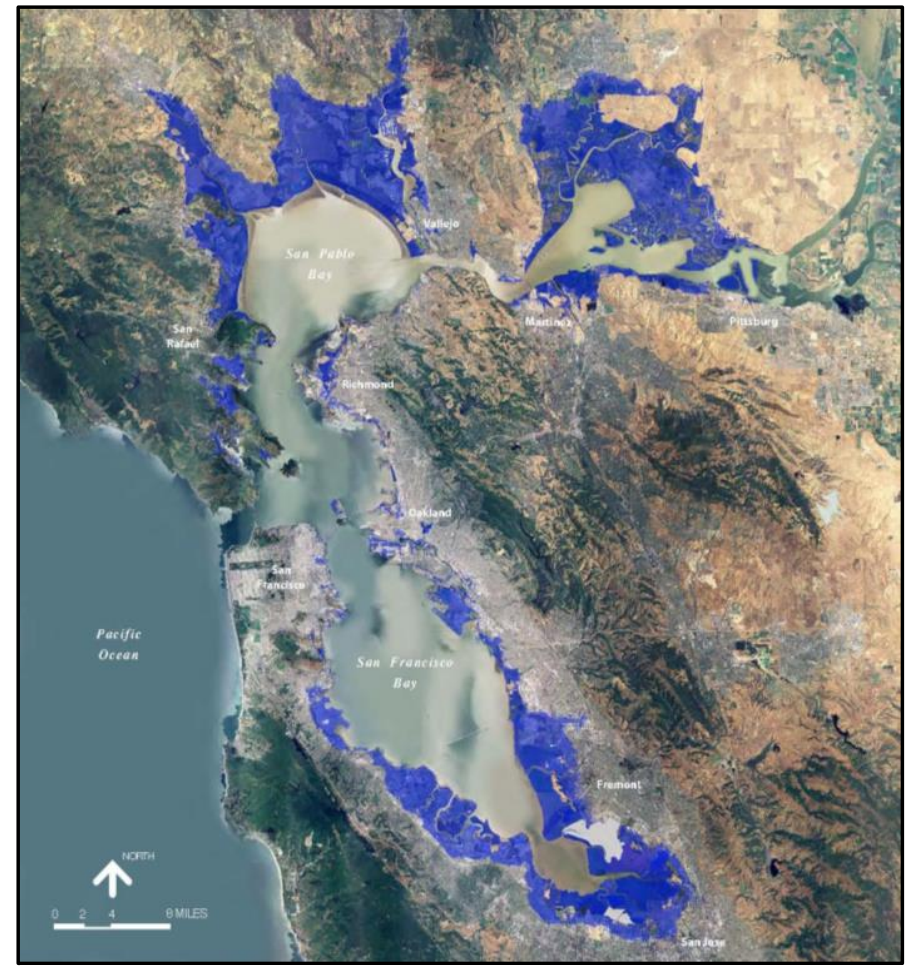

Figure 1: Predicted Sea Level Rise in San Francisco in 2100 put 480,000 people at risk of a 100 year flood event, given today's population. The current 100 year high tide peak would become a 10 year high tide peak, causing more frequent risks of inundation.

3. A wide range of critical infrastructure, such as roads, hospitals, schools, wastewater treatment plants, power plants, and more will be at increased risk of inundation in a 100 year flood event.

4. An estimated 550 square miles of wetlands along the California coast are vulnerable to sea level rise, especially if marine life cannot move further inland because of levees, bulkheads, and seawalls and other development blocking inland migration.

5. Nearly $\$ 100$ billion worth of property is at risk of flooding from a 1.4 meter sea level rise, and the majority of this property is residential development. 
6. Approximately 1,100 miles of new or modified coastal protection structures are needed to protect the Pacific Coast and the San Francisco Bay. The total cost of building new or upgrading existing structures is estimated at $\$ 14$ billion and that the operating and maintaining cost estimate is another $\$ 1.4$ billion per year.

Despite the fact that specific climate change predictions are considered uncertain, it is nevertheless a fact that measures must be taken in the San Francisco Bay Area to guard against, or to take advantage and adapt to, flooding and high water levels.

\subsection{Why live on water?}

Currently, living on water is a niche market and is not considered equivalent to a house built on land by the majority of the population in the United States. But with an ever growing population that tends to migrate towards water and the gradual rise in sea level, urban areas must consider expanding new development on the water. Not only have water dwellings proven efficient in times of extreme flooding, but the cost of building and living in a water dwelling can be significantly less than a house built on land.

\subsubsection{Urban congestion}

Today, waterfront cities are beginning to recognize the negative consequences of such a massive population movement into urban areas. In order to deal with the growing density of these urban metropolises, the natural instinct is to build up and in, creating a

much more dense area within their city boundaries. However, urban sprawl has led to cities branching out in all directions to accommodate the growing population migration. With the majority of the worlds most populated mega-cities are located along the coasts 
and the growing concern over the inevitable rise of ocean sea levels, a new typology for mitigating urban congestion must be considered, such as building on water.

\subsubsection{Proven Mitigation Method}

Building on water is not a new method of mitigation. People have lived on and next to water for centuries; building communities on floating reeds, elevating houses on piles, retrofitting boats to become residences and designing amphibious architecture have been used to adapt to water regions around the world. Now is the time for coastal regions to adapt to rising water levels by learning to live with water, not defend against it.

\subsubsection{Cost}

Building on water is financially feasible at locations where building on land is expensive and where there is little of no alternative space on land. Today, water dwellings can be built in numerous ways, in multiple sizes with a wide range of foundation systems and materials. If you buy a house on water, it is assumed that the materials and maintenance are equivalent to a house built on land, the only essential difference being the foundation, not the structure.

The Make it Right Foundation designed a prototype amphibious residence in New Orleans. At 940 square feet, the price for one of these homes is $\$ 150,000$ approximately $20 \%$ more than a house in New Orleans. However, elevating a land built house to the required base flood elevation height costs about $\$ 48,000$. The cost of the house and the required elevation will leave the owners paying more than the price for an amphibious house. In addition, Dura Vermeer, a Dutch construction firm, have built over 30 amphibious homes along the River Maas, with prices starting at $\$ 310,000$ for a 1,300 
square foot home, approximately $17 \%$ less than a typical 1,300 square foot house in Maasbommel. Although factors such as location and market rates may affect the price of a house, water dwellings have the capability to be built at a lesser cost while ensuring the safety of its inhabitants during a sudden rise in sea level.

\subsection{Water Dwelling Typologies}

Water dwellings can be categorized by their foundations and their relationship to the water. These dwellings include terp dwellings, static elevation, pile dwellings, amphibious dwellings and floating dwellings. Some types have been used for centuries while others are relatively new, such as the amphibious house, however each type has proven resilience in the event of rising water levels.

\subsubsection{Terp Dwellings}

A terp is an artificial earthwork mound created to provide safe ground in the event of a rise in water levels. (Figure 2) The first terps were built in the Netherlands, dating back to 500 B.C., where tides from the nearby rivers affected daily routines. The terps were built up to 15 meters high,

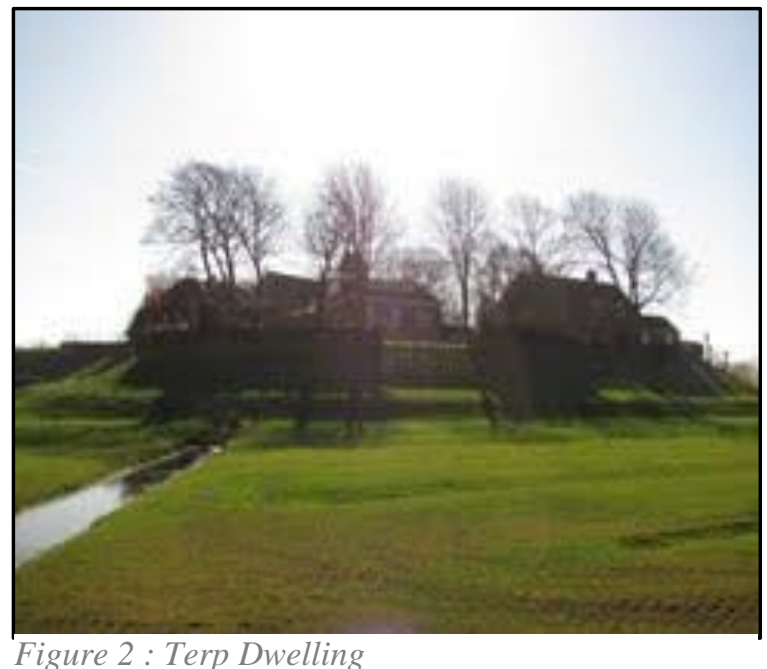
and was intended to keep a house dry and provide enough space for cattle and food storage. Around 1000 A.D., the inhabitants began to connect these mounds to prevent the sea from flooding their lands, commencing the formation of a permanent dyke system. 
The terp dwelling is connected to the land and remains dry until a maximum water level has been reached. Although it intuitively feels safer and more secure than a floating dwelling, it is in fact less safe because there are no means of escape during extreme and unexpected high water levels.

Today, few modern terps can be found throughout Europe, one such example is the Bridge House in Achterhoek, Netherlands by 123DV Modern Villas. In this case, the landscape architect removed the top layer of the soil throughout the property in order to make the soil less fertile for the replanting of indigenous trees. The soil was then reused to form a raised area beneath the house in the event of high water levels, resulting in a traditional Dutch terp dwelling.

\subsubsection{Static Elevation}

One of the most common retrofitting methods is elevating a house to a required or desired Base Flood Elevation (BFE). When a house is properly elevated, the living area will be above all but the most severe floods (Figure 3). Several elevation techniques are available. In general, they

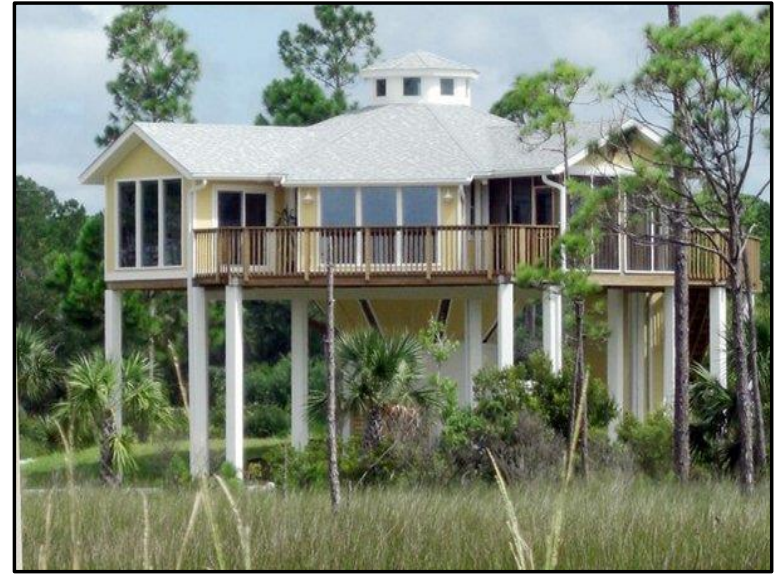

Figure 3: Static Elevation involve (1) lifting the house and building a new, or extending the existing, foundation below it or (2) leaving the house in place and either building an elevated floor within the house or adding a new upper story. 


\subsubsection{Pile Dwellings}

Pile dwellings are a type of housing built on top of concrete, steel or wooden poles and can be found in shallow water, coastal areas, or lakes where fluctuations in the water level can be predicted. This type of dwelling typically rests 8-15 feet off the ground and has been used throughout the world as means of protection from water. In Indonesia, Singapore, and other countries, "kelong" are built for fishing, but may double as offshore housing. The "Nipa hut" is the primary type of housing found in the Philippines, and a similar stilt house structure is also popular in Papua New Guinea. Thai stilt houses are often built above freshwater, and the "Palafito" is found in the tropical river valleys of South America. Stilt houses are also gaining popularity in the United States, particularly along the Gulf Coast, where the threat of hurricanes is severe.

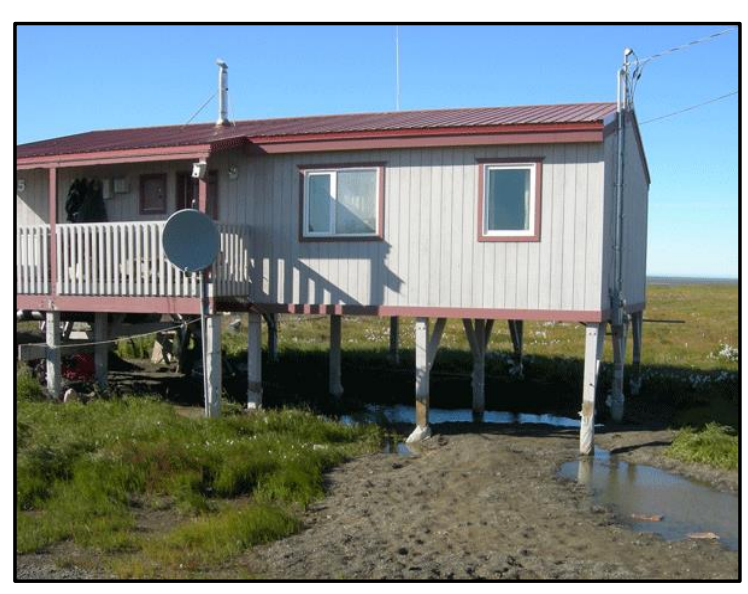

Figure 4 : Timber Pile Residence
Timber pilings have been used for 6,000 years and continue to be one of the leading types of driven piles. Timber is often used in pile foundations because it is a readily available and renewable resource. (Figure 4) Because it is light in weight, timber is also more easily handled, driven and cut

than other types of piles. According to the Federal Highway Administration, timber pile foundation underwater will last indefinitely and timber piles partially above water can last up to 100 years or longer if they are properly prepared and treated. 
Concrete piles can be pre-cast or cast-in-place, and they can be reinforced, prestressed or plain. They do not corrode like steel piles or decay like wood piles; also, concrete is more readily available than steel. Pre-cast concrete piles are shaped and molded according to shape, length and size prior to being driven into the ground, while cast-in-place piles are poured into holes in the ground where a rod has been previously driven and removed.

Steel pilings can be formed into many different shapes but the most common steel pile types have rolled circular, X-shaped or H-shaped cross sections. They are very strong and are great for driving, especially in firm soil and can be easily cut off and can also be

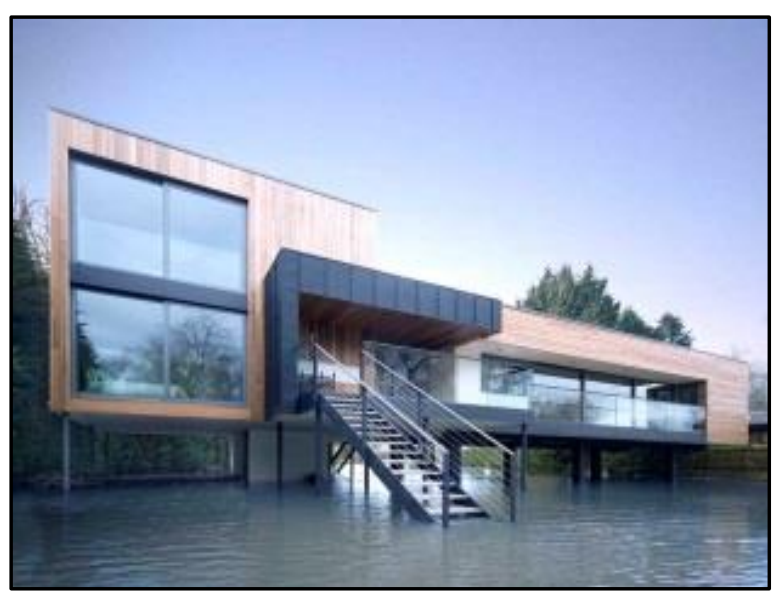

Figure 5: Steel Pile Residence easily joined by welding. Although steel pilings can last up to 100 years, they are prone to corrosion, especially when submerged in water. (Figure 5)

\subsubsection{Houseboats}

Houseboats began with the conversion of ships and fishing vessels into livable environments. (Figure 6) These types of houses resemble a landbased property in its design and construction yet are buoyant enough to

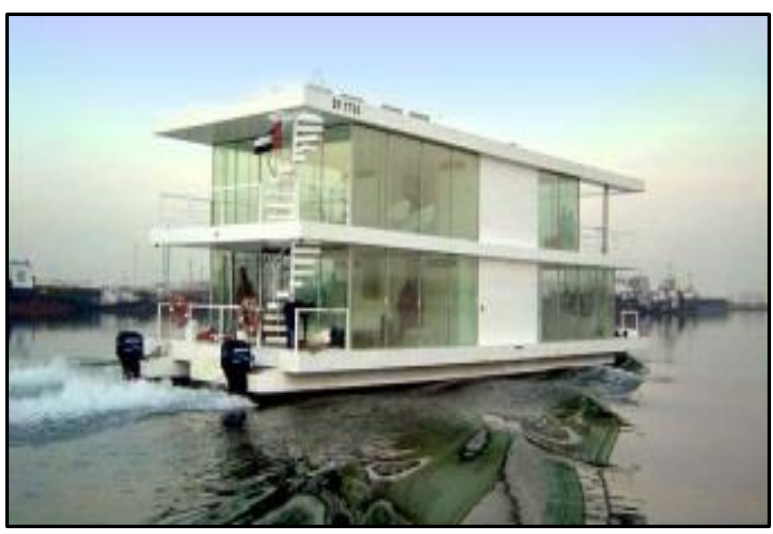

Figure 6: Houseboat Residence 
withstand the forces of water. The dwellings have been a part of American history since the early 1900s where the earliest houseboats in Seattle were recorded in 1905, and peaked with over 2,000 houseboats in the 1930s. During the 1940s, World War II brought much activity to the shores of California as shipbuilders and factory workers were transported to San Francisco. The need for housing brought many workers to transform old fishing boats and decommissioned war surplus into residential dwellings in Sausalito Bay.

Some of the more modern examples of floating homes are those built by Dutch architects including Waterstudio.nl, Aquatecture, Factor Architecten and Architectenbureau Marlies Rohmer. The trend to build residences on water has enticed many homebuyers in coastal countries in Europe however it has yet to fully catch on in the United States.

\subsubsection{Amphibious Dwellings}

Amphibious housing is a dwelling type that sits on land but is capable of floating. (Figure 7) During a sudden rise in water, a house will be lifted by the water, provided either by pontoons or a hollow basement, in order to ensure it remains dry, and will then return to the

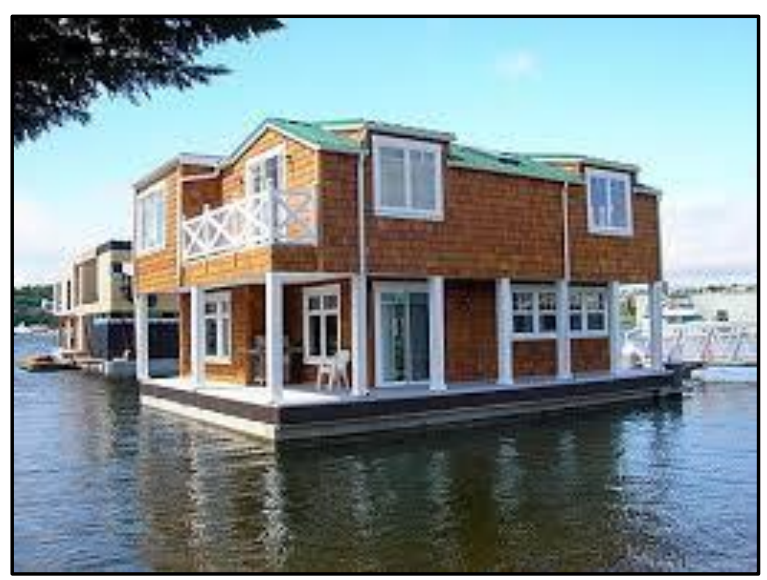

Figure 7 : Amphibious Residence 
ground as the water recedes. By sliding along two vertical mooring poles that are driven deep into the ground, the houses are capable of rising vertically while restricting horizontal movements on the water.

Although the amphibious house resembles a houseboat, there are some essential differences between the two types. The hollow basement of an amphibious house is exposed when there is no water, forcing designers to conceal the base in the ground or in water. The second difference is the distribution of forces in the base. When the property is sitting on land it lacks the even upward force of the water which it experiences when it floats, making the basement larger than that of the barge of a houseboat. The biggest difference between houseboats and amphibious homes is their connection to land. Typically, amphibious homes are designed where water levels are moderate but are rarely prone to extreme flooding, therefore all utility services can be connected to the municipal pipes whereas houseboats must contain all utilities within the structure. Examples of these houses can be found throughout the Netherlands, most notably the Maasbommel water dwelling situated along the River Maas.

A list of the advantages and disadvantages of each type of water dwelling can be found in Table 1. 
Table 1 : Advantages \& Disadvantages of Water Dwelling Typologies

\begin{tabular}{|c|c|c|}
\hline & Advantages & Disadvantages \\
\hline Static Elevation & $\begin{array}{l}\text { - Elevates house to required base flood } \\
\text { elevation level } \\
\text { - preserves original architecture } \\
\text { - capable of high density houses }\end{array}$ & $\begin{array}{l}\text { - Difficult access to living areas } \\
\text { - increased vulnerability to winds } \\
\text { - house can still be flooded due to height } \\
\text { limitations }\end{array}$ \\
\hline Terp & - Can be used for large plots of land & $\begin{array}{l}\text { - Difficult access to living areas } \\
\text { - house can still be flooded due to height } \\
\text { limitations } \\
\text { - residents cannot leave house when } \\
\text { flooding occurs }\end{array}$ \\
\hline Pile & $\begin{array}{l}\text { - A solution when there is a lack of } \\
\text { construction ground } \\
\text { - capable of high density houses } \\
\text { - minimized carbon footprint }\end{array}$ & $\begin{array}{l}\text { - house can still be flooded due to height } \\
\text { limitations } \\
\text { - increased corrosion due to its } \\
\text { submergence in water }\end{array}$ \\
\hline Amphibious & $\begin{array}{l}\text { - A solution when there is a lack of } \\
\text { construction ground } \\
\text { - house remains on the ground under } \\
\text { normal conditions but will rise when } \\
\text { flooding occurs } \\
\text { - utilizes municipal pipes and electrical } \\
\text { connections } \\
\text { - mooring posts allow house to rise and } \\
\text { fall with minimal lateral sway } \\
\text { - capable of high density houses } \\
\text { - minimized carbon footprint }\end{array}$ & $\begin{array}{l}\text { - It is subject to stronger external loadings } \\
\text { due to wind, rain and ice } \\
\text { - house must be loaded symmetrically to } \\
\text { maintain even levelling } \\
\text { - height limitations are restricted to the } \\
\text { mooring post height }\end{array}$ \\
\hline Floating & $\begin{array}{l}\text { - A solution when there is a lack of } \\
\text { construction ground } \\
\text { - capable of mobility } \\
\text { - no height restrictions allow the house } \\
\text { to rise and high as any water level } \\
\text { - minimized carbon footprint }\end{array}$ & $\begin{array}{l}\text { - It is subject to stronger external loadings } \\
\text { due to wind, rain and ice } \\
\text { - increased corrosion due to its } \\
\text { submergence in water } \\
\text { - house must be loaded symmetrically to } \\
\text { maintain even levelling } \\
\text { - must accommodate all plumbing and } \\
\text { sewerage fixtures within the house }\end{array}$ \\
\hline
\end{tabular}

\subsection{Summary of Water Dwelling Typologies}

Although there are many types of strategies to defend against rising sea levels, amphibious buildings are a proven flood protection strategy that gives a community enhanced flood resilience and improves its ability to recover from disaster. When flooding occurs, the house vertically rises with the water levels to remain safely above water then settles back into place as the water recedes. In addition, comfort is guaranteed because all buildings will have the same facilities as a building on land, including 
heating, cooling and ventilation and utilizes the same municipal pipes and electrical connections. The buildings and places that we create in the next ten years will form the backbone of an amphibious lifestyle for the next five decades and beyond. In order to prepare for the future, designers and builders must not look at the limitations of water, but at the opportunities it presents. 


\section{Chapter 3 \\ Precedent Studies}

\subsection{Introduction}

The vision for developing waterfront owes itself to a diverse set of precedents. The following section is a collection of precedents that range from the urban to architectural scale for the purpose of identifying key themes that will facilitate the origination of new construction in Redwood City. These precedents include waterdwellings in Sausalito Bay, the Buoyant Foundation Project and FLOAT House in New Orleans, and waterdwellings in the Netherlands including Maasbommel and Ijburg.

\subsection{Sausalito Bay, California}

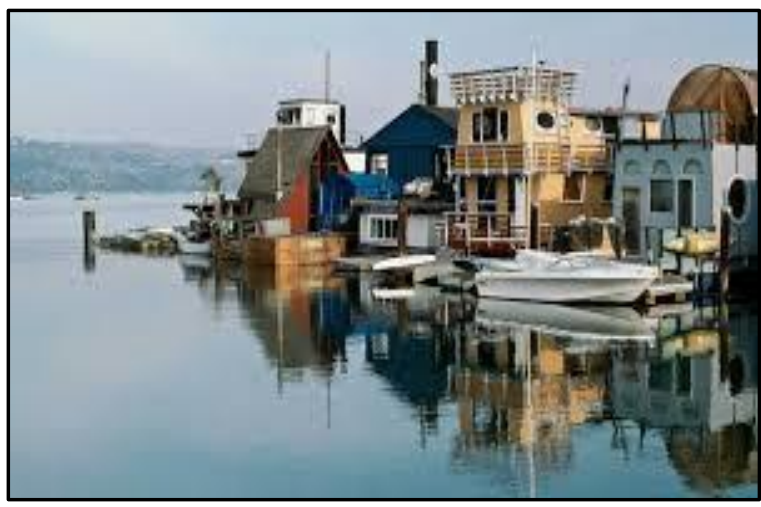

Water Type: Salt Water

House Type: Varies

Buoyancy Materials: Pontoons, Barge, or EPS

Size: Varies

Advantages: Capable of withstanding cracking and erosion

Disadvantages: Lack of organized sewerage and waste disposal

Figure 8: Sausalito Houseboat Community

Sausalito is a small city on San Francisco bay to the north of the Golden Gate waterway, the strait connecting the bay with the Pacific Ocean. Today, the city is also home to some 460 houseboats afloat on the bay, some dating back to the early $20^{\text {th }}$ century. (Figure 8) After the 1906 earthquake in San Francisco, many residents whom had lost their homes in the devastating fires decided to take up permanent residence in their summer homes in the bay. The homes were towed to the shore and moored to piles along the shoreline in order to facilitate daily access to the surrounding city. 


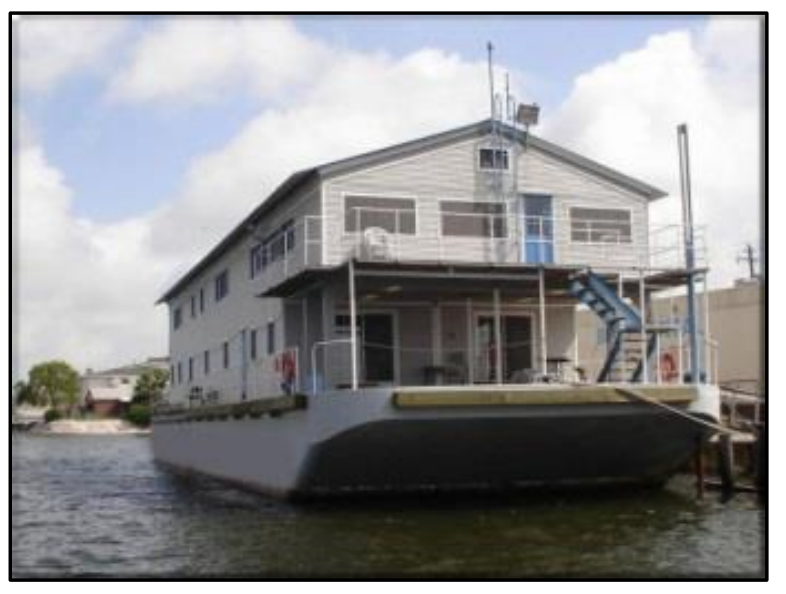

Figure 9: Barge Houseboat
One of the first types of boats to be converted to residential homes was hay barges and their crew barges. (Figure 9) Originally used to haul hay to San Francisco, the barges were approximately 32'x110'while the crew barges were typically 16'x32'. (Shaffer, 83) The floors

to the barges were constructed with two layers of two-inch thick tongue and groove planking, laid perpendicular to each other. The interior of the barge contained only three or four columns down the middle of the floor, allowing the space to remain open while having the flexibility to construct any required walls. There was typically a slight bow in the roof, serving both as a walking deck and providing additional structural strength. Although most hay barges have been transferred to pilings, some are still floating with the addition of hallow concrete basements.

During the 1940s, World War II brought much activity to the shores of California as shipbuilders and factory workers were transported to San Francisco. The need for housing brought many workers to transform old fishing boats and decommissioned war surplus into residential dwellings. Many Landing Craft Vehicles (LCV), designed by Andrew J. Higgins Industries, proved to be extremely durable, inexpensive, and highly available. These boats were constructed of wood and steel and had the ability to carry fully armed troops, light tanks, and field artilleries. Capable of operating in only eighteen inches of water, the LCVs were built to run up on land and over obstacles, making it a valuable vehicle in low tide. Other types of reused boats include tugboats, riverboats, 
fishing boats, and old decommissioned ships. Workers scavenged for scrap building materials and pontoons to transform the old boats into two-story floating homes, eventually drawing vagrant hippies and artists to the community. Facilities on the shoreline such as showers and waste tanks were shared throughout the community however the facilities were unprepared to accommodate the accelerated growth and the shared facilities became intolerable. The lack of sewerage and organized waste disposal was a threat to public health; the outfalls from the toilets on the houseboats spilled directly into the bay causing damage to both residents and the wildlife.

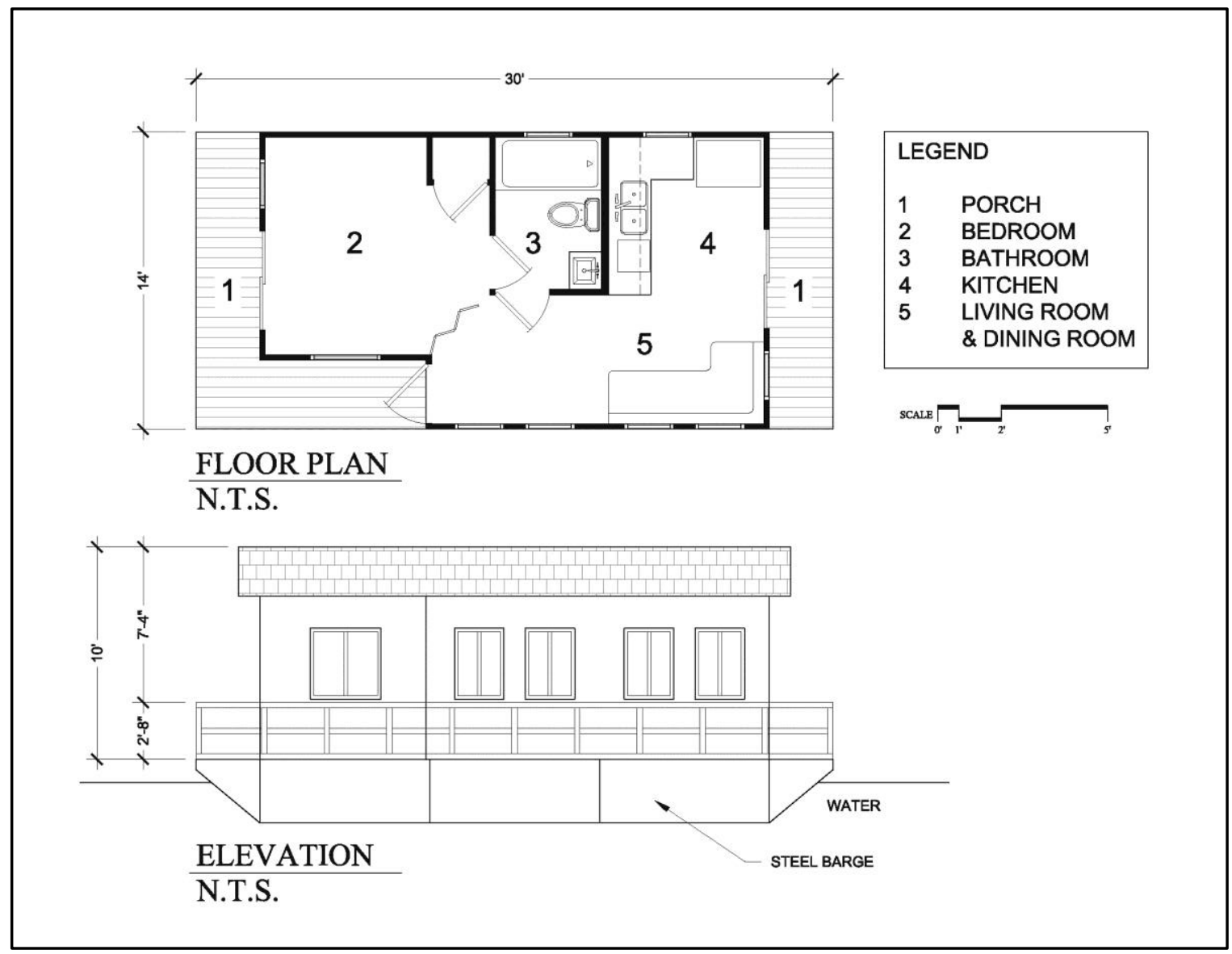

Figure 10: Houseboat Floor Plan \& Section Drawing 
A summary of the policies pinpoints certain regulations for the community including the limitation of the sizes of the houseboats, preserving waterfront views, the connection to municipal services such as sewerage and electricity, and the ability to float in all tidal heights of water. By code, each houseboat has its own 30-40 gallon sewage and gray water receiving tank and ejector device that will pump sewage and gray water into the sewer pipes that run beneath the piers and connects to the sewer system. Not all residents wished to conform to the new policy, so the unused moorings were filled with other self-built and often modernized houseboats. Many of these homes were built on 3' thick blocks of 4'x8' polystyrene foam, laid flat to create a 12'x40' rectangle. The foam based was secured with pressure treated wood and wood floor framing. Rooms containing the most amount of weight, such as the kitchen and bathroom, were placed in the middle of the plan and allowed the houseboat to remain stable.

Today, Sausalito Bay contains close to 500 eclectic houseboats arranged along landings built atop piles. Communal spaces are informally designated with flowerpots and sitting areas whereas front porches boast private garden areas. While licenses for houseboats in the bay have to be renewed every 20 years and the rent for mooring is approximately $\$ 550$ per month, the floating homes in Sausalito Bay have grown to accommodate a large number of residents who have the desire to live close to water.

\subsection{New Orleans}

Founded by the French in 1718 , the town of New Orleans was built at a natural levee embankment on the lower Mississippi River. By 1803, the town quickly became the largest U.S. city in the south, expanding its footprint east and west along the river. To the 
north of the city, marshlands frequently flooded every spring, causing developers to cut a series of three drainage channels where water could be pumped into Lake Pontchartrain to avoid flooding. However the pumps proved unreliable and the low lying parts of the city were repeatedly flooded after heavy rainfall.

Hurricane Katrina marks a turning point for the city of New Orleans. While the city had been flooded by hurricane storm surges three times in the past century, the flooding was most extensive in 2005 when more than $80 \%$ of the city was left underwater after the passage of

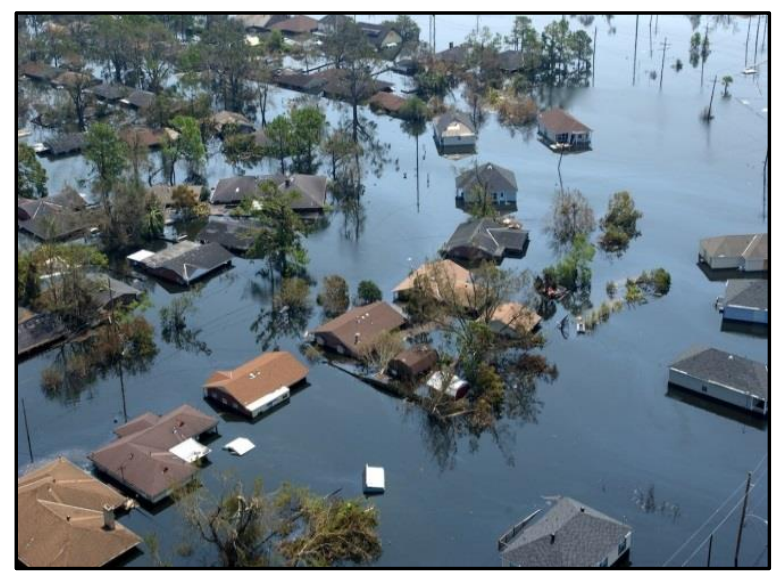
Figure 11: Flooded Houses in New Orleans Hurricane Katrina. (Figure 11) Levee failure, storm surge, strong winds, and massive rainfall inundated the majority of New Orleans's infrastructure and claimed over 1,800 lives. While the levee defense system could accommodate a maximum of 15.5 feet, the Mississippi River Gulf Outlet was recorded to have a 16.5 feet rise in water levels, causing neighborhoods to be flooded. It is estimated that between $10 \%$ and $20 \%$ of the water which flowed into the downtown area came from openings in the flood defenses along the three drainage channels. (Grossi \& Muir-Wood, 8)

After Hurricane Katrina, the Federal Emergency Management Agency (FEMA) issued a report on the impacts of the hurricane. The report acknowledged that flood levels from Hurricane Katrina in many areas exceeded the 100-year Base Flood Elevations 
(BFEs) shown on current FIRMs by up to $15 \mathrm{ft}$. As a result, the Code of Ordinances of New Orleans adopted flood regulations for the development of new construction and tenant improvements on March 11, 2010. Ordinance No. 23911 Article II Section 70-78 states, "All building permits issued for new construction or substantial improvements must have imprinted upon them the mean sea level elevation of the lowest floor (including basement) and the base flood level of the 100-year storm. Such elevation requirements apply to all new residential and nonresidential structures as well as substantial improvements." Although raising the house above the BFE is the most common method of floodwater mitigation, many buildings that had been constructed with their lowest floor above the BFE were still destroyed or severely damaged by flood waters.

Though permanent static elevation has shown success in mild storms and average flood levels, alternative methods have been considered to help protect against severe flood levels and prove community resilience.

\subsubsection{Buoyant Foundation Project}

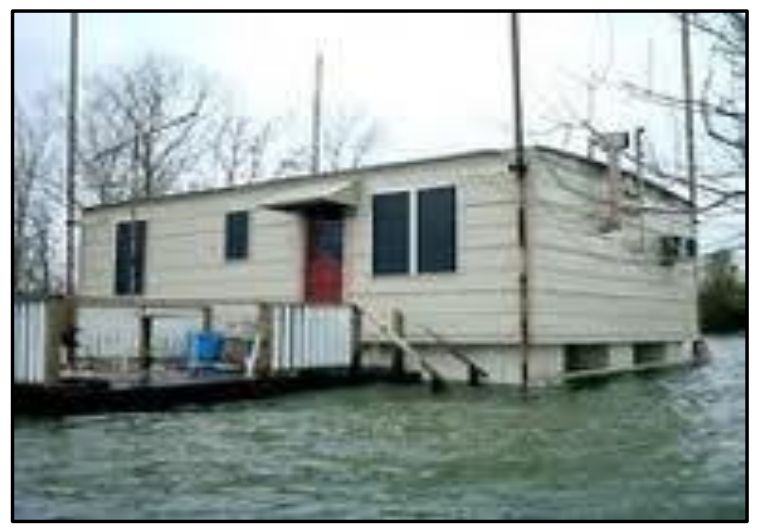

Water Type: Salt Water

House Type: Amphibious

Buoyancy Materials: Sub-frame w/ EPS Blocks Size: $700 \mathrm{ft}^{2}$

Advantages: Retain existing house, retrofit is cheaper than static elevation Disadvantages: Visible EPS foundation system, height restrictions

Figure 12: House with Buoyant Foundation

The Buoyant Foundation Project (BFP) is a non-profit research program, founded by Dr. Elizabeth English in 2006, that was the first initiative to apply amphibious 
foundations to existing residences in New Orleans in order to prevent the flooding of houses. A prototype of a "shotgun" house, a typical style of residence in the south consisting of a narrow rectangular frame, was built in order to test the buoyancy of the house once it had been retrofitted with the amphibious sub frame. (Figure 12) The structural sub-frame attaches to the underside of the house and supports the floatation blocks made of Expanded Polystyrene Foam (EPS). Extensions of the structural subframe attach to the tops of vertical guidance poles near the corners of the house that telescope out of the ground to provide resistance to lateral forces from wind and flowing water. When flooding occurs, the flotation blocks lift the house, with the structural subframe transferring the forces between the house, blocks and poles. The vertical guidance poles keep the house from going anywhere except straight up and down on top of the water.

The construction and retrofit process of the house is relatively simple and it basically works like a floating dock. (Figure 13) The process begins by drilling into the ground and inserting the vertical guidance sleeves in the appropriate locations. Next a steel frame is constructed by securing C-channels to

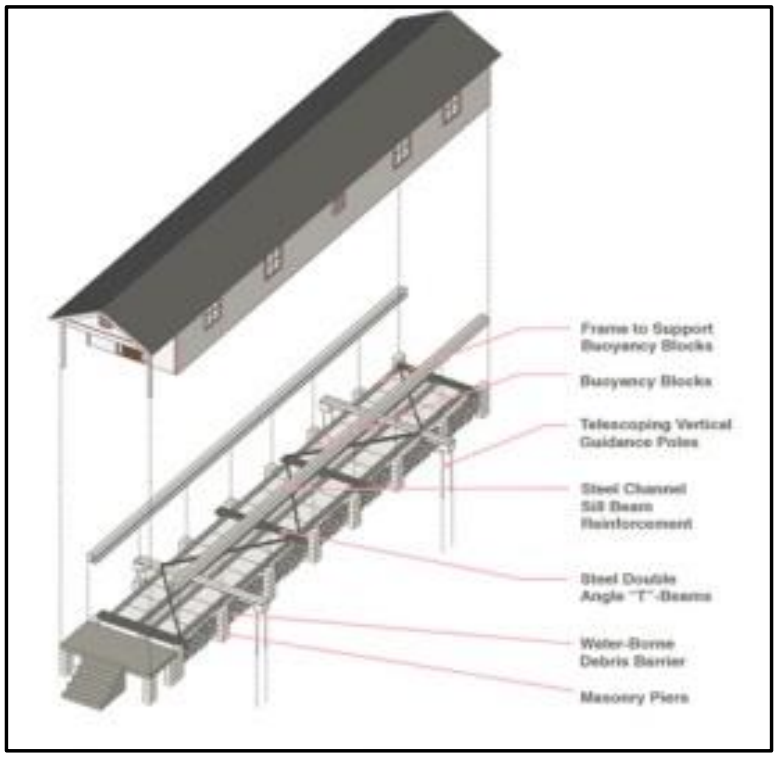

Figure 13 : Buoyant Foundation Materials 


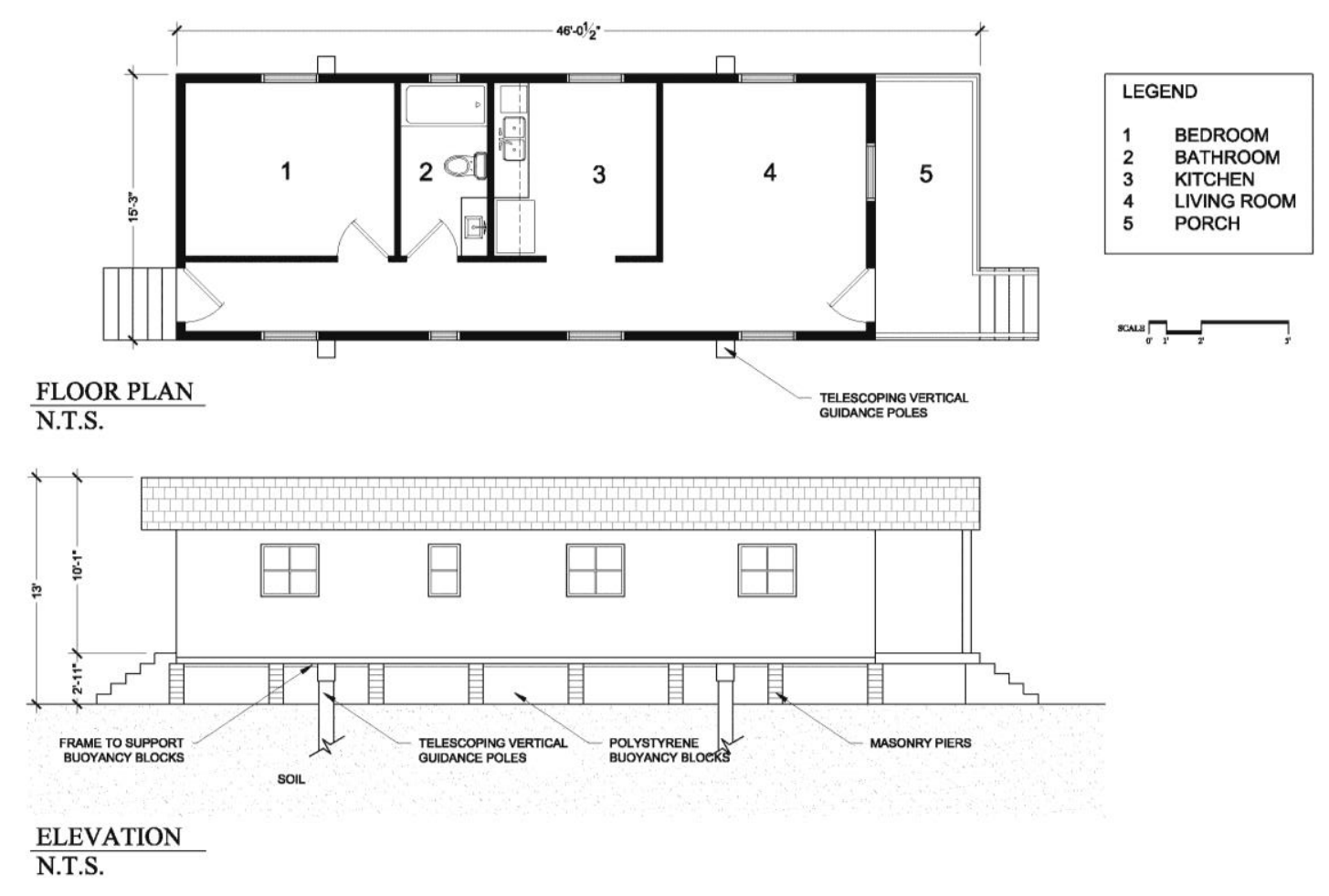

Figure 14: BFP Floor Plan \& Section

the wood sill beams of the house, and then positioning and securing extended T-beams to the C-channels. The house is then slowing jacked up to five-feet in small increments where the plumbing and utility lines are modified. The plumbing and utility lines have either self-sealing 'breakaway' connections that disconnect gas and sewer lines when the house begins to rise or long, coiled 'umbilical' lines that can stretch as the house rises. The rest of the T-beams and C-channels are connected to form the structural sub-frame as well as the addition of diagonal L-beams. EPS blocks are then inserted into the sub-frame and the frame is then connected to the house. The house is then lowered in small increments where it rests 3-4 feet off the ground. The vertical guidance poles are inserted into the sleeves and connected to the extended T-beams in the sub-frame. Most of the construction materials are small and light enough to be installed by two persons without 
machinery. After the buoyant foundation is in place, the house remains supported on its original piers except when flooding occurs.

In 2007, a team comprised of Louisiana State University students and faculty successfully constructed and tested a full-scale prototype buoyant foundation system installed on a platform structure representing the full width (13 ft) and 40\% (24 ft) of the full length (approx. $60 \mathrm{ft}$ ) of a typical shotgun house. The finished prototype successfully demonstrates the ability of an existing residence to rise and fall with the water and thus ensure the protection of the inhabitants and their belongings. The buoyant bases allow the residents of New Orleans to protect and preserve their existing vernacular homes and maintain neighborhood character. This approach to flood mitigation is considerably less expensive (\$20-25k US) than permanent static elevation (\$40-60k US). They alleviate any long-term deterioration of protection resulting from soil subsidence and elevated sea level from global warming, something that permanent static elevation cannot avoid. The house is not permanently elevated and it is therefore less vulnerable to hurricane wind damage. The Buoyant Foundation Project promotes restoration rather than demolition and proves community resilience in extreme weather events and rising water levels. 


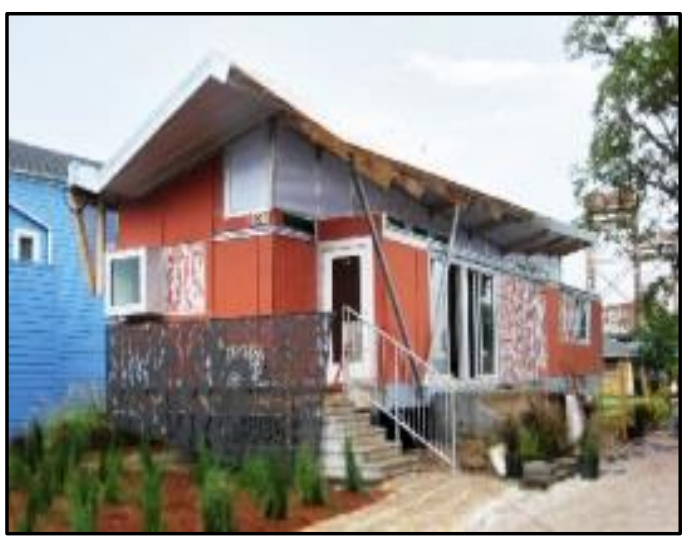

Figure 15: FLOAT House
Water Type: Salt Water

House Type: Amphibious

Buoyancy Materials: GFRC Coated EPS Blocks Size: $940 \mathrm{ft}^{2}$

Advantages: Maintains neighborhood character, high-performance systems

Disadvantages: Residents cannot remain in house during flooding

Developed to meet the needs and budget of families in New Orleans's Lower Ninth Ward, the FLOAT House is a prototype for prefabricated, affordable housing that can be adapted to the needs of flood zones worldwide. (Figure $15 \& 16$ ) Architect and UCLA distinguished professor, Thom Mayne, seven graduate students from the UCLA Department of Architecture and Urban Design, and architects from Mayne's firm, Morphosis, have created the first floating house permitted in the United States.

The FLOAT House reflects the vibrant culture of New Orleans while maintaining the vernacular design of the typical shotgun houses that are predominant throughout the Lower Ninth Ward. Like a typical shotgun house, the FLOAT House sits atop a prefabricated

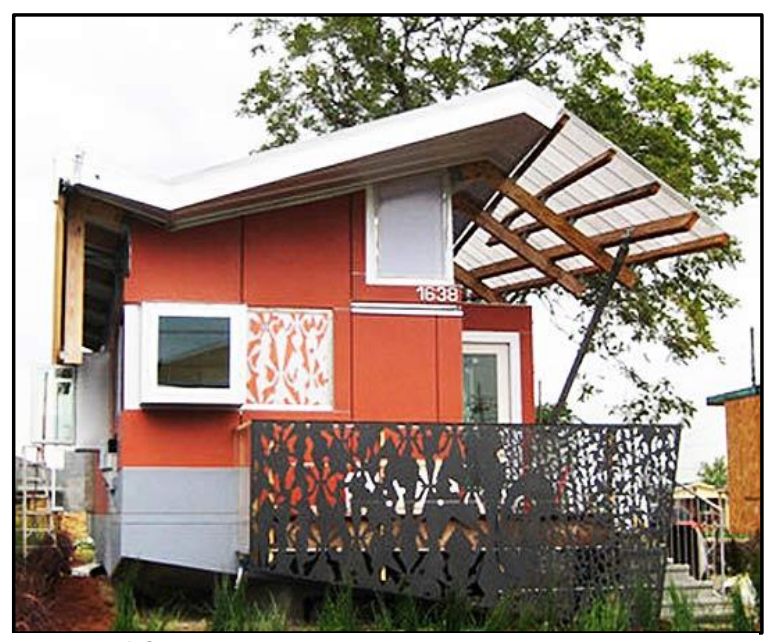

Figure 16: FLOAT House raised base made comprised of expanded polystyrene foam coated in glass fiber reinforced concrete. This configuration accommodates a traditional front porch, 
preserving of the community's vital porch culture and facilitating accessibility for elderly and disabled residents. (Figure 15) The 4-foot base integrates all mechanical, electrical, plumbing and sustainable systems and allows the house to rise in the case of severe flooding. The prefabricated base is shipped whole from factory to site, via standard flatbed trailer.
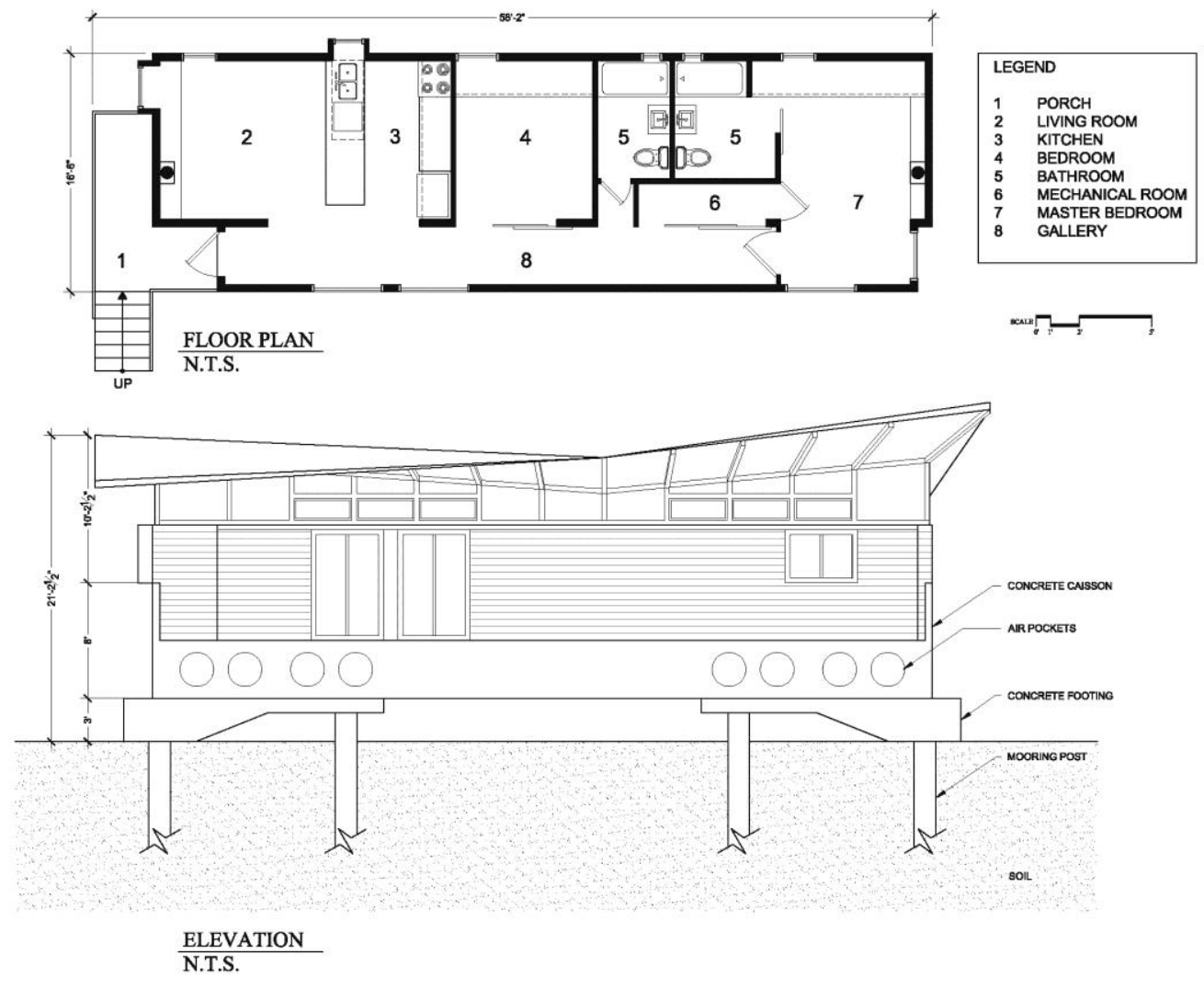

Figure 17: FLOAT House Floor Plan \& Section

The FLOAT House is connected to vertical guideposts which are anchored to the ground by two concrete pile caps, each driven 45 -feet into the ground. The vertical piles and the concrete pads on which the base sits are constructed on-site allowing the house to rise up to twelve feet as water levels rise. (Figure 17) The panelized walls, windows, 
interior finishes and kit-of parts roof are prefabricated, to be assembled on-site along with the installation of fixtures and appliances. This efficient approach integrates modern mass-production with traditional site construction to lower costs, guarantee quality, and reduce waste.

While the house is still relatively new to the market, Morphosis is hoping to obtain a LEED Platinum Rating. Some of the high-performance systems in the house include solar power generation, rainwater collection, high-efficiency plumbing and appliances, and geothermal heating and cooling. The roof supports solar panels that generate all of the house's power, resulting in net-zero annual energy consumption. The prefabricated base incorporates electrical systems to store and convert solar power for daily use, and to give back to the electrical grid during the temperate fall and spring months. The sloped concave roof collects rainwater, and funnels it to cisterns housed in the chassis, where it is filtered and stored for daily use. High-grade energy efficient kitchen appliances and fixtures maximize durability and reduce the need for replacement while low-flow plumbing fixtures minimize water consumption. High performance windows and insulated SIPs (Structural Insulated Panels) in the walls and roof minimize power consumption. A geothermal mechanical system heats and cools the air via a ground source heat pump, which naturally conditions the air, minimizing the energy required to cool the house in the harsh summer months and heat it in winter.

Morphosis states that, "While not designed for occupants to remain in the home during a hurricane, the FLOAT House aims to minimize catastrophic damage and 
preserve the homeowner's investment in their property. This approach also allows for the early return of occupants in the aftermath of a hurricane or flood.”(Morphopedia.com)

\subsection{Netherlands}

The earliest inhabitants of the river area, between the lower Rhine and the Maas Rivers, began settling on elevated former river channels called creek ridges. These river channels are separated by the lower laying areas called "komgronden" (roughly translated: bowl-grounds) which flooded during the winter but were used for cattle grazing during the summer season. By the $10^{\text {th }}$ century, the population was increasing and more land was required for agriculture and livestock. The land near the rivers was drained for the purpose of cultivating, leading to the subsidence of the land and hence more susceptible to flooding. In order to protect themselves from flooding, the people constructed dikes that diverted floodwater from the upper sections of the river around their cultivated land.

Although these dikes prevented annual flooding, the Dutch faced a new range of problems. Every year that the river flooded, new material was deposited between the dikes, causing the riverbed to be slowly lifted above the floodplain whole reducing the water storing capacity. In response, the dikes were raised in height, hence increasing the hydrostatic pressure of the floods between the dikes. Over time, an increasing number of dike breaches and residential flooding occurred.

By the $17^{\text {th }}$ and $18^{\text {th }}$ centuries, the construction of overflow and lateral diversion channels was utilized. An overflow is a deliberately lowered dike section that could be easily and quickly lowered further as an emergency outlet in the case of dangerous high 
water levels. The overflowing water was then channeled over land, sometimes between low dikes, downstream to another section of the river or an entirely different river. The downside of this system was that significant areas of land could be underwater for several months per year, forcing residents to sell their land and relocate.

By the mid-19th century a flexible river management system had developed that did not resist floods but controlled it by increasing the capacity of the river. By adding extra flow channels in the form of the overflow and lateral diversion system that channeled the water into retention basins or downstream, the Dutch were able to increase the capacity of floodwaters. By the second half of the $19^{\text {th }}$ century, the number of spill channels decreased in order to minimize the amount of flooding on potential agricultural land. Once the spillways were closed, the Dutch decided to build larger and heavier dikes in order to control the flow of water and protect valuable agricultural land, towns and villages.

In 1953 , the coast of the Netherlands was hit by a hurricane, inundating the southwestern part of the country, killing over 1,800 people in the flood. After the disaster, Dutch Government introduced a plan that aimed at

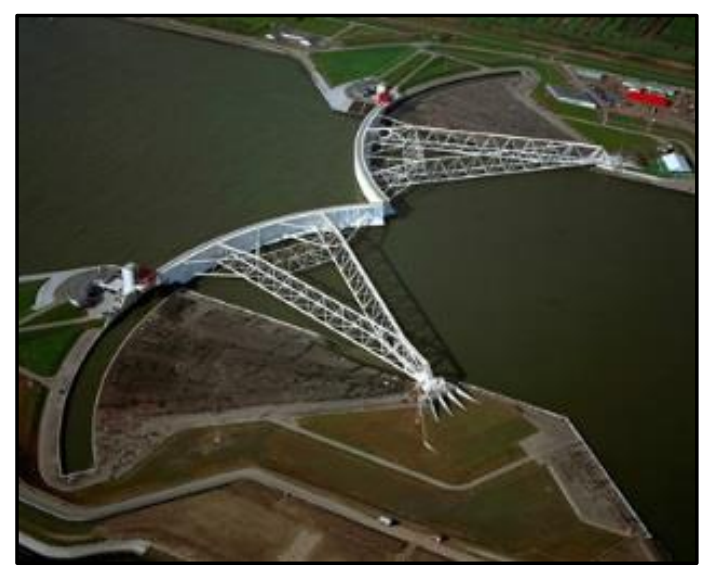
reinforcing the water defenses and to shorten Figure 18: Maeslannt Barrier the coastline by closing estuaries with large dams, including the Maeslannt Barrier. Known as the Delta Plan, the project aimed at protecting the coast in a manner that reduced the risk of a disaster such as the 1953 flood. The curving gates and three 
enormous trusses of the Maeslant Barrier are as tall as the Eiffel Tower. (Figure 18) When storm-driven waters rise too high, the two curved arms of the Maeslant stormsurge barrier swing into place on ball bearings to block the channel and protect the agriculture land and towns from flooding.

By the year 2000, the Dutch government began to reevaluate their flooding mitigation strategies. Instead of raising the dikes, the government began a new program called "Room for the River." This strategy involved moving the dikes back to widen the flood plain and lowering the forelands. Another stipulation of the Room for the River program was that its work should not come at the sacrifice of valuable features of landscape, nature, and cultural history, which has inspired a holistic regional planning approach, taking into account not just settlements but recreational opportunities, transport infrastructure, and natural reserves. Although this strategy has been successful for the past twelve years, the Dutch have developed other alternatives for adapting to rising water levels, including the introduction of floating architecture.

\subsubsection{Maasbommel Waterdwellings}

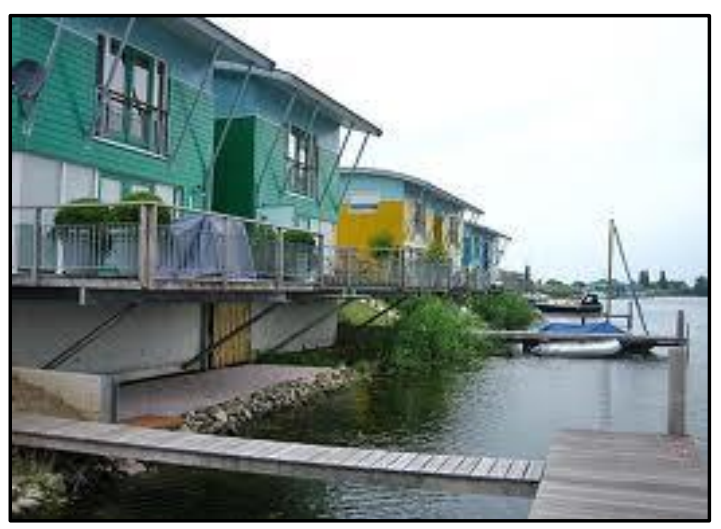

Water Type: Fresh Water

House Type: Amphibious

Buoyancy Materials: Concrete with Rebar

Size: $2,865 \mathrm{ft}^{2}$

Advantages: Attached houses become more stable, low erosion, utilization of river embankment for infrastructure

Disadvantages: Close proximity to neighbors

Figure 19: Maasbommel Waterdwellings 
Rising waters have ignited the creation of a new market in floating housing in the Netherlands. After three years of negotiations with Rijkswaterstaat (the Dutch equivalent of the American U.S. Army Corps of Engineers), the construction company Dura Vermeer was given a permit for the construction in the Maasbommel River of 34 amphibious houses designed by Factor Architecten and Dura Vurmeer. (Figure 19 \& 20) Amphibious architecture, structures designed to function both on land and water, is a response to the risk of floods in low lying areas such as the Netherlands. The amphibious houses are constructed along the Maasbommel River and are able to rise with incoming water and return to their original locations on the ground when the water recedes.

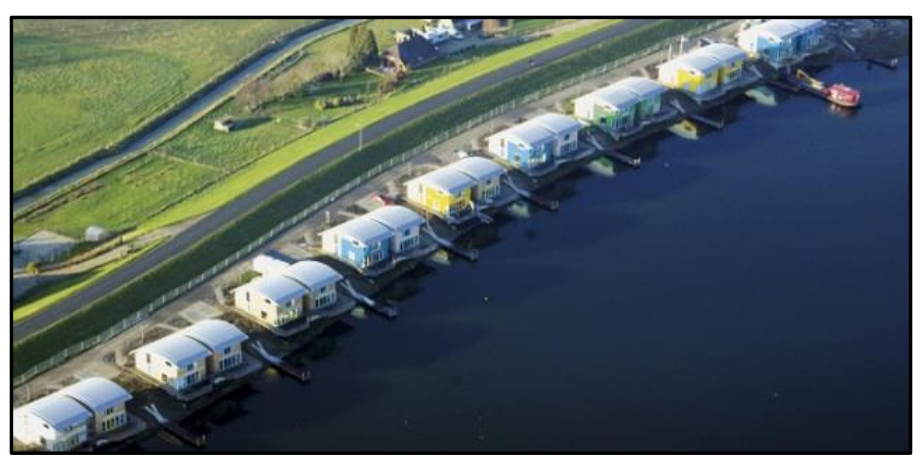
Figure 20: Maasbommel Community

The houses are built on top concrete basements that double as a buoyant foundation, making it a water tight hollow space used for resident occupancy and flotation. (Figure 21) The concrete basements are constructed on site and reinforced with steel rebar. The concrete is poured in detached pairs with each basement weighing in at 70 tons. Two fifteen-foot steel vertical guidance posts are driven through the concrete slab and into the banks of the river. When the guidance posts are in place, the concrete basements are hoisted into position and the wood-frame houses are constructed overtop of them. Each pair is placed onto a concrete slab or on concrete piles. The concrete slab is used for amphibious houses that typically rest on dry land. At a low water level, the houses rest upon a foundation of concrete. The concrete piles are used as a base to rest 


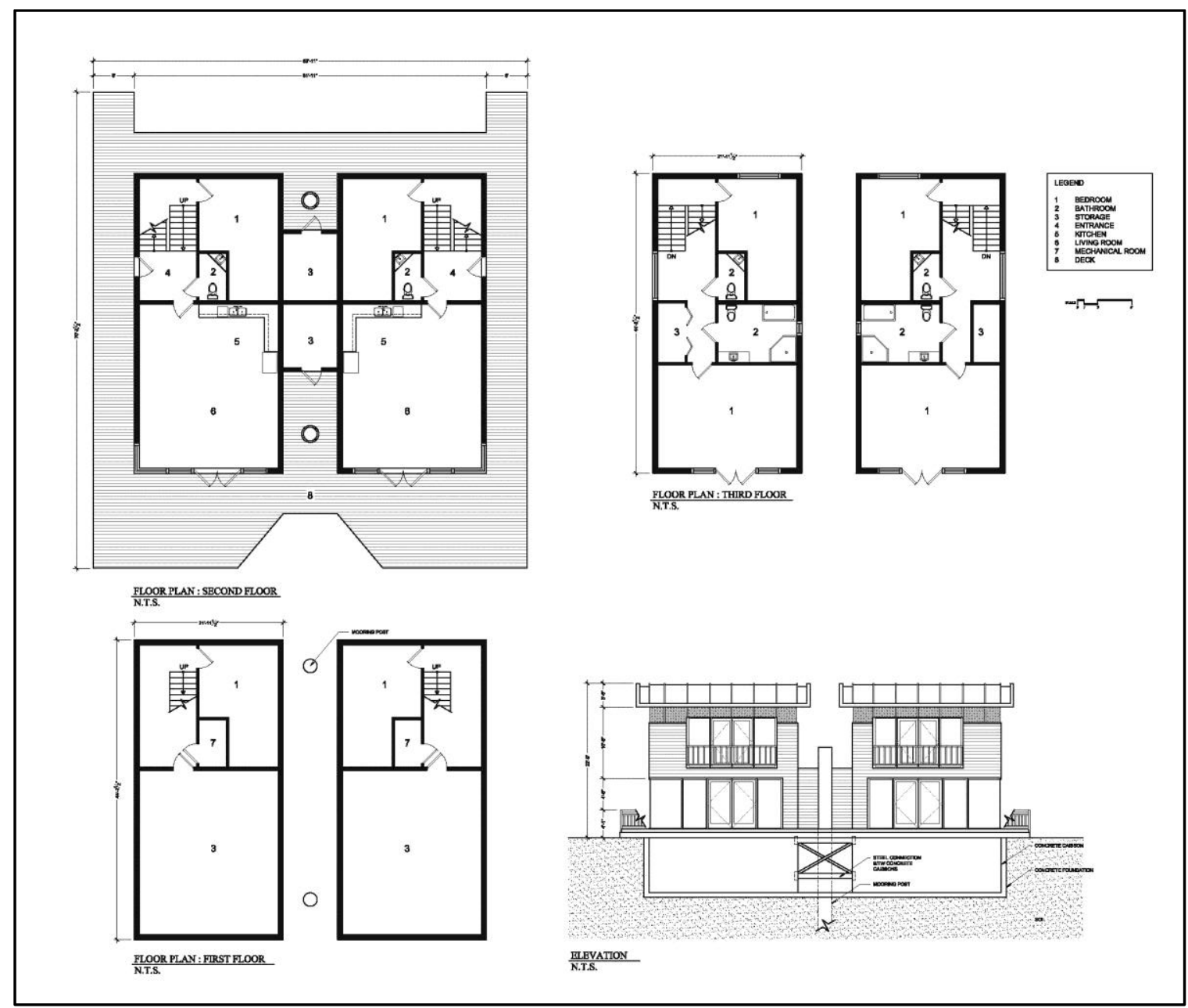

Figure 21 : Maasbommel Floor Plan \& Section

upon at a low water level for floating houses that typically reside in water year-round. To keep the houses as light as possible the framework consists of timber. The houses are joined by a steel bracing that straps two steel plates to the corners of each of the concrete basements. These steel braces will allow both houses to rise and fall with the water at the same rate. The roof is assembled on site and hoisted overtop the pre-fabricated timber frame house. When water levels are high, the houses can reach a maximum height of 18 feet by sliding along the two vertical guidance posts. The vertical guidance posts restrict lateral movements from currents and waves, ensuring that the houses will not float away 
in the event of high tides. The poles also carry all the electrical cables, water and sewage flow through flexible pipes inside the mooring poles.

\subsubsection{Waterdwellings IJburg}

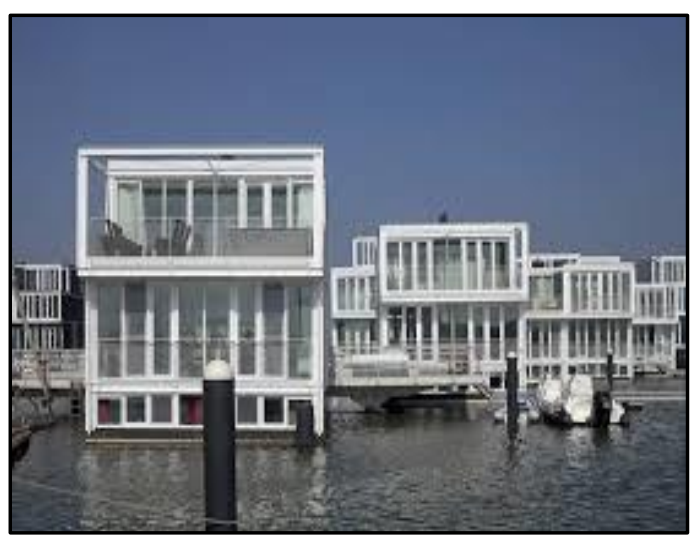

Figure 22: Waterdwellings Ijburg
Water Type: Fresh Water

House Type: Amphibious

Buoyancy Materials: Concrete with Rebar

Size: $3,024 \mathrm{ft}^{2}$

Advantages: Large amounts of interior space, private jetty system for residents

Disadvantages: Height of house causes minor sway, no nearby land for outdoor activities, higher corrosion rate

Another example of Dutch floating architecture is the Waterdwellings IJburg located on the IJ Lake between Zeeburgereiland and Haveneiland. IJburg is a new district on the east side of Amsterdam. (Figure 22) Spread across six islands, the area is expected to contain 18,000 homes for 45,000 citizens once fully complete. At the moment, the district houses around 15,500 residents, who began moving into the first completed properties in 2001. Steigereiland is the first island in the IJburg island chain comprised of two neighborhoods with floating and platform homes in the inland waterways. Waterbuurt West is a compact urban district with a density of 60 homes per hectare while the other residential that neighborhood is comprised of a row of customized platform homes built along the dike. (Figure 23)

Designed by Architectenbureau Marlies Rohmer, the dwellings are prefabricated, with the factory residing over 30 miles from IJburg. The construction crew starts building the base of the structure first, pouring all four walls and floor with concrete at once 
without joints. This method of construction was utilized in order to prevent cracks in the base and ensure that the structure is watertight. Some residents of the Waterdwellings IJburg were certain of their furniture placement prior to occupancy, hence some concrete bases

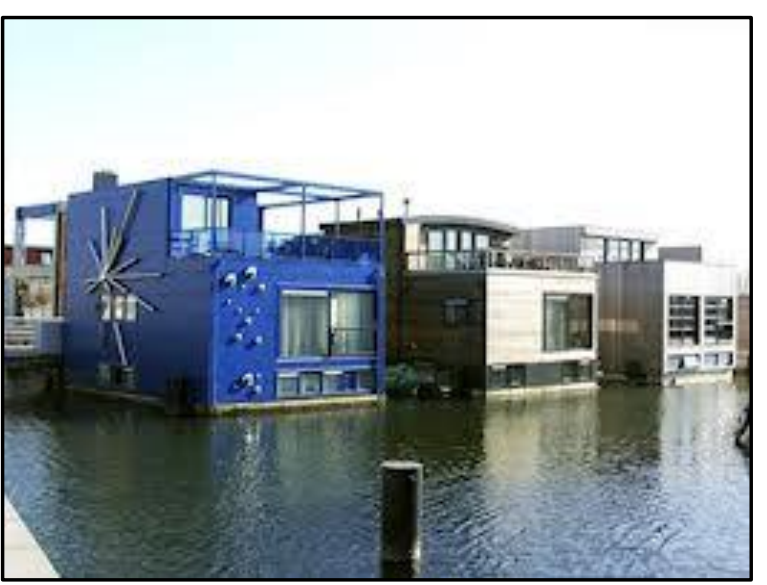

Figure 23 : Ijburg Residences were poured with varying wall thicknesses, allowing the construction crew to accommodate the weight of the furniture. After the walls of the dwelling are fused with the base and the structure nearly complete, the factory floods its facilities in order to float the dwellings and move the individual units to IJburg.

The individual units are built with a 15-foot width, ensuring that the homes will fit through the narrow canals of the Netherlands. (Figure 24) Because the units are built to hold up to a ton of weight, they are extremely buoyant in the factory and are susceptible to tipping over. In order to prevent this, the construction crew temporarily places $10-400$ pound barrels in the base of the house to level out the unit during transport. After 8 hours of travel from the factory, the unit arrives by tugboat to IJburg.

Once at IJburg, two individual units are connected together using steel plates. A 1-inch gap is left between the units in order to minimize damage to the bases caused by water pressure. Once connected, the 30-foot wide double-occupancy unit becomes ten times more stable than an individual 15-foot wide unit. Two mooring posts that are driven 20-feet into the lakebed prevent the homes from lateral sway. Brackets are used to 
attach the home to the mooring posts, which are placed diagonally from each other to further prevent sway from waves.

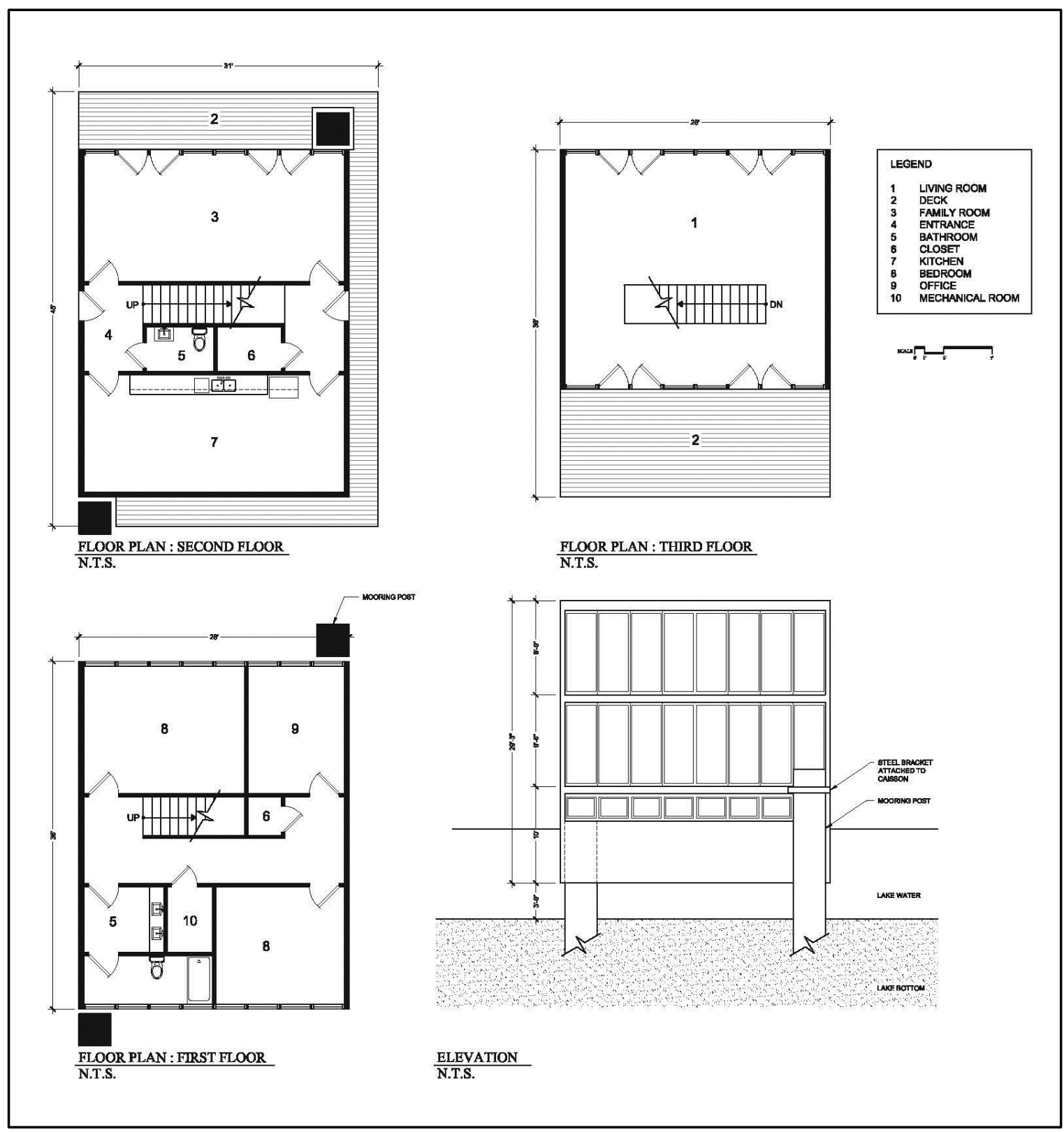

Figure 24 : Ijburg Floor Plan \& Section

Differences in height between the jetty, water, and front door on the ground floor are bridged by means of a boardwalk around the home that slopes down to the water. (Figure 25) The boardwalks also make it possible to walk around the homes - like on a 
boat - and have close contact with the water. (rohmer.nl) The neighborhood layout is in a triangular allotment with varied distances between the dwellings as well as their orientation, creating continuously varying views for the residents. Space is reserved between the homes for boats to be docked. In total, there are now 93 floating homes, and another 72 will follow, plus a small number of houseboats that are now moored at locations elsewhere in Amsterdam.

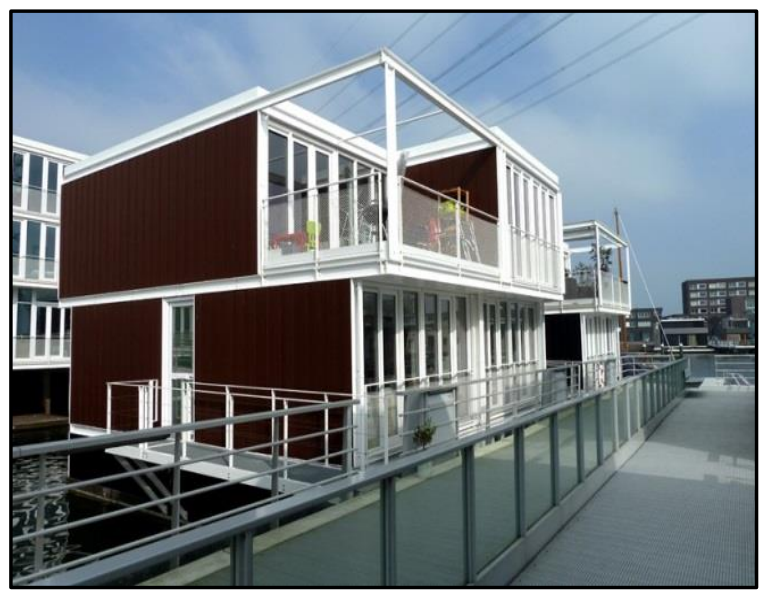

Figure 25 : Ijburg Residence on Boardwalk

Residents in flood prone areas around the globe are showing resistance to permanent static elevation, which has been a common strategy to keep homes above water levels. Despite the efforts of raising the structure on a plinth or stilts, protection from floods remains unpredictable due to a limit in elevation. The Netherlands, like Redwood City, resides on a delta and is one of the most vulnerable locations for rising sea levels. Although dikes are capable of preventing the inundation of agriculture, towns, and critical infrastructure, the sea level continues to heighten and amphibious and floating dwellings have proven successful in the event of rising water levels.

A summary of the precedent studies can be found in Table 2 along with a summary of the advantages and disadvantages of each study. 
Table 2 : Summary of Precedent Studies

\begin{tabular}{|c|c|c|c|c|c|}
\hline & Sausalito & $\begin{array}{c}\text { Buoyant } \\
\text { Foundation } \\
\text { Project }\end{array}$ & FLOAT House & Maasbommel & Ijburg \\
\hline Water Type & Salt & Salt & Salt & Fresh & Fresh \\
\hline House Type & Floating & Amphibious & Amphibious & Amphibious & Floating \\
\hline $\begin{array}{l}\text { Flotation } \\
\text { Materials }\end{array}$ & $\begin{array}{l}\text { Pontoons, barge, or } \\
\text { EPS Blocks }\end{array}$ & $\begin{array}{l}\text { Sub-frame w/ EPS } \\
\text { Blocks }\end{array}$ & $\begin{array}{l}\text { GFRC Coated EPS } \\
\text { Blocks }\end{array}$ & Concrete w/ Rebar & Concrete w/ Rebar \\
\hline Size (square feet) & Varies per house & $700 \mathrm{ft}^{2}$ & $940 \mathrm{ft}^{2}$ & $2,865 \mathrm{ft}^{2}$ & $3,024 \mathrm{ft}^{2}$ \\
\hline $\begin{array}{l}\text { Maximum } \\
\text { Vertical Rise } \\
\text { (feet) }\end{array}$ & Varies per House & $13 \mathrm{ft}$ & $12 \mathrm{ft}$ & $18 \mathrm{ft}$ & $15 \mathrm{ft}$ \\
\hline Advantages & $\begin{array}{l}\text { - Capable of } \\
\text { withstanding wind, } \\
\text { waves and } \\
\text { corrosion }\end{array}$ & $\begin{array}{l}\text { - Uses existing } \\
\text { house } \\
\text { - Maintains } \\
\text { neighborhood } \\
\text { character } \\
\text { - Retrofit is } \\
\text { cheaper than static } \\
\text { elevation }\end{array}$ & $\begin{array}{l}\text { - Maintains } \\
\text { neighborhood } \\
\text { character } \\
\text { - High- } \\
\text { performance } \\
\text { building, pre- } \\
\text { fabricated }\end{array}$ & $\begin{array}{l}\text { - Attached homes } \\
\text { minimize sway } \\
\text { from waves, vast } \\
\text { interior space } \\
\text { - Levee berm } \\
\text { allows house to } \\
\text { rest on land, } \\
\text { minimizing } \\
\text { corrosion }\end{array}$ & $\begin{array}{l}\text { - Pre-fabricated } \\
\text { - Vast interior } \\
\text { space }\end{array}$ \\
\hline Disadvantages & $\begin{array}{l}\text { - No organized } \\
\text { sewerage or waste } \\
\text { disposal }\end{array}$ & $\begin{array}{l}\text { - Visible EPS } \\
\text { foundation system } \\
\text { - Vertical height } \\
\text { restrictions }\end{array}$ & $\begin{array}{l}\text { - Cannot remain in } \\
\text { house during } \\
\text { flooding } \\
\text { - Vertical height } \\
\text { restrictions }\end{array}$ & $\begin{array}{l}\text { - Close proximity to } \\
\text { neighbors } \\
\text { - Vertical height } \\
\text { restrictions }\end{array}$ & $\begin{array}{l}\text { - Close proximity to } \\
\text { neighbors } \\
\text { - Height of house } \\
\text { causes sway from } \\
\text { waves } \\
\text { - No nearby land } \\
\text { - Vertical height } \\
\text { restrictions }\end{array}$ \\
\hline
\end{tabular}

\subsection{Summary of Precedent Studies}

The houseboat community in Sausalito has a population of over 700 people with an average resident age of 51 years, similar to that of Redwood City, which indicates that residents are willing to live on water. The soil consists of Novato Clay, the same soil as that of the salt ponds, and resides below the sea water in the San Francisco Bay. Because many of the houseboats in Sausalito are converted hay barges and have withstood the power of the coastal wind, waves and corrosion, this precedent study has determined that I will utilize a barge for the foundation of the house. 
The Buoyant Foundation Project has proven it can withstand extreme flooding by retrofitting an existing house with EPS buoyancy blocks. However, the corrosion rate for the EPS blocks is higher than that of steel, therefore I will omit the use of EPS blocks as the primary foundation and rather use them within the barge for added buoyancy.

Although the residents of the FLOAT House are unable to remain in their home during a flood, this precedent study will help me to design efficiently. The prefabricated house is a tested model for a high-performance building that can lend its sustainable aspects to my design.

Both the houses in Maasbommel and in Ijburg utilize concrete caissons for their foundations and are connected side-by-side to minimize sway from waves. Although the corrosion rate for concrete is higher in salt water than that of steel, I will utilize a concrete platform, such as that in Maasbommel, for the house to rest on. This precedent has helped determine that residents prefer more space between neighbors. Therefore I will design an unattached, single house with a maximum of two stories to minimize sway from waves while allowing residents to have personal space. 


\section{Chapter 4}

Project Location

\subsection{Redwood City, CA}

Redwood City is located in the Bay Area 25 miles south of San Francisco, and about 27 miles north of San Jose. (Figure 26) The city has a total area of 34.6 square miles, of which 19.4 square miles is land and 15.2 square miles is water. The 2010 United States Census reported that Redwood City had a population of 76,815 with a population density at 2,218.5 people per square mile. (Redwood City General Plan, BE-12)

\subsection{Existing Land Use}

Redwood City is developed with residential, commercial, industrial,

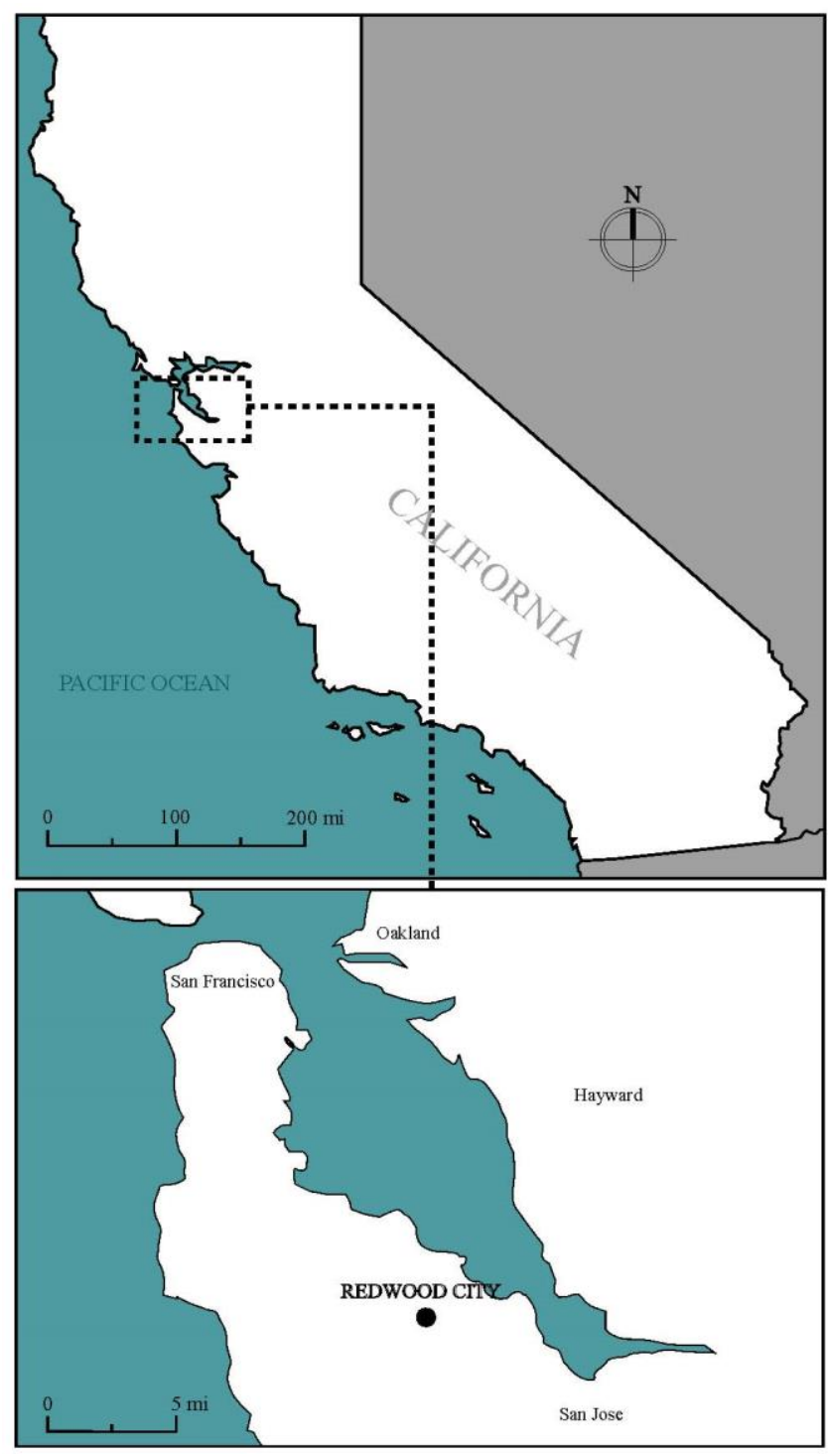
institutional, public uses, and Figure 26: Map of Redwood City

streets/highways. Residential is the largest single land use of which single family units represent the majority of all housing with each neighborhood influenced by a predominant housing and architectural style. With a clear goal to promote higher density, 
efforts to revitalize and enhance these neighborhoods center on the balance between preservation of historical character and attracting new development.

\subsection{Population Trends and Housing}

A community's population characteristics affect the amount and type of housing needed. Factors such as population growth, age, income, and employment trends influence the type of housing needed and households' ability to afford housing. The city's population increased at a rapid rate in the 1980s and 1990s, as there remained vacant land suitable for development in Redwood Shores, but has remained steady at two percent since 2000. The Association of Bay Area Governments projects steady in Redwood City through 2030, with a projected increase in population of approximately 16 percent between 2000 and 2030 .

According to the 2011 U.S. Census and the 2011 American Community Survey, approximately 28,000 housing units are occupied by residents of Redwood City. In those 28,000 housing units, over 14,000 are owner occupied and less than 13,000 are renter occupied. The average owner occupied household size is approximately 3.25 persons per unit with the median household income residing at approximately $\$ 77,550$ per year. A household is defined by the Census as all persons who occupy a housing unit, which may include families, single persons, and unrelated persons sharing a housing unit. Persons residing in group quarters such as dormitories, retirement homes, or prisons are not considered households. The average selling price per home for the year 2013 was $\$ 808,600$. (Redwood City General Plan, H-13) 
The characteristics of a community's households serve as important indicators of the type and size of housing needed in the city. For instance, single-person households often occupy smaller apartment units or condominiums, such as studio and one-bedroom units. Married couples often prefer larger single-unit homes, particularly if they have children. In 2000, there were 28,060 households in Redwood City appearing to be a stable, family-oriented community, with 64 percent of those households classified as single-family households.

\subsection{Historical Flooding and Mitigation Efforts}

Historically, the Redwood City neighborhoods have experienced some degrees of flooding during storms, mostly due to overwhelming drainage infrastructure. The city has over 100 miles of storm drain pipe, 75 tide gates, 82 open culverts, and over 10 miles of creeks, drainage ditches, and canals. Rainwater collects in catch basins, flows to the creeks, then downhill to one of 17 pump stations. These stations pump the storm water into the Bay to keep it from flooding low-lying areas of the City. The City's 75 tide gates keep high tides from pushing 'upstream' and overloading already-swollen creeks and basins, and during low tide the gates let creek water flow into the Bay. (Redwood City

General Plan, BE-34) Flooding usually occurs when heavy rainfall coincides with high bay tides, thereby impeding runoff flow into the Bay and storm flows in excess of design capacity. Storm drains that are clogged with leaves and debris can also increase the chances of flooding during storms. 
Large areas of the City lie within 100 or 500 year flood plains. Floods are described in terms of their extent (including the horizontal area affected and the vertical depth of floodwaters) and the related probability of occurrence. The magnitude of flood used as the standard for floodplain management in the United States is a flood having a probability of occurrence of 1 percent in any given year. This flood is also known as the 100-year flood or base flood.

A common approach to mitigating flood risk is to construct a barrier between the structure and source of flooding, the most common barrier being a levee. A levee is typically a compacted earthen structure that blocks floodwaters from coming into contact with the structure. Levee embankment and foundation are made up of medium-stiff to stiff-silty and sandy clay fill over a layer of soft to medium-stiff young bay mud followed by alluvial deposit consisting of medium-stiff to very-stiff clays embedded with dense sands. The FEMA has defined a levee in the National Flood Insurance Program (NFIP) regulations as "a man-made structure, usually an earthen embankment, designed and constructed in accordance with sound engineering practices to contain, control, or divert the flow of water so as to provide protection from temporary flooding." (fema.gov)

Levees can be built to any height, but are usually limited in height due to cost, aesthetics, access, water pressure, and space. Local zoning and building codes may also restrict use, size, and location. The design standard for levees is currently based on either (1) the 100-year standard of the NFIP, or (2) the level of protection justified using federal, development-oriented policy that attempts to maximize the net national economic development return to the nation. In September, 2009, Redwood City completed its plan 
for the Redwood Shores levee improvement project. The improvements were needed to meet levee certification requirements of FEMA and NFIP, in order to prevent the imposition of mandatory flood insurance and result in the removal of the flood zone designation for Redwood Shores. Increased development in these flood risk areas provides a short-term economic benefit with potentially long-term adverse consequences.

When levees fail, either by structural failure or overtopping by flood waters that exceed the design event, the results are often catastrophic, with the levee experiencing massive damage. As accentuated by the levee failures in New Orleans in 2005, a 100- or 200-year level of protection is insufficient to avoid catastrophic losses and their resultant financial implications to all federal taxpayers. Although a catastrophic levee failure of the magnitude and impact of that experienced in New Orleans is uncommon, current planning processes for levees fail to capture the magnitude of this impact and the resulting economic, social, and environmental consequences.

In many instances it is useful to design levees to withstand overtopping, or to control the overtopping to a limited number of planned spillways in the system. The aim is to prevent loss of the levee, by allowing it to be overtopped and slowly flood the area in planned locations rather than randomly, so that damage is reduced and the community can recover more quickly. However there are many adverse effects to rebuilding and improving levees. According to the Association of State Floodplain Managers, "Levees by their very nature adversely affect properties that are upstream, downstream, adjacent to, or across the waterway. Levees transfer flood waters onto other property, interfere 
with the natural attenuation of flows, cause backwaters, generally increase depth and velocity of flood waters, and encourage channel degradation and eventual bank erosion." Although levees provide short-term protection from flood waters and high tides, alternative long-term mitigation efforts must be considered that have much less adverse consequences.

\subsection{Site Location : Redwood City's Urban Reserve Salt Ponds}

With an effort to accommodate an ever growing city, coastal land known as urban reserve was preserved for future use to expand the limits of the urbanized area of Redwood City. The urban reserve is located east of the city center with Redwood Creek to the west, open space reserve to the east, the San Francisco Bay to the north, and highway 101 to the south. The site is bounded on the northwest by Pacific Shores office

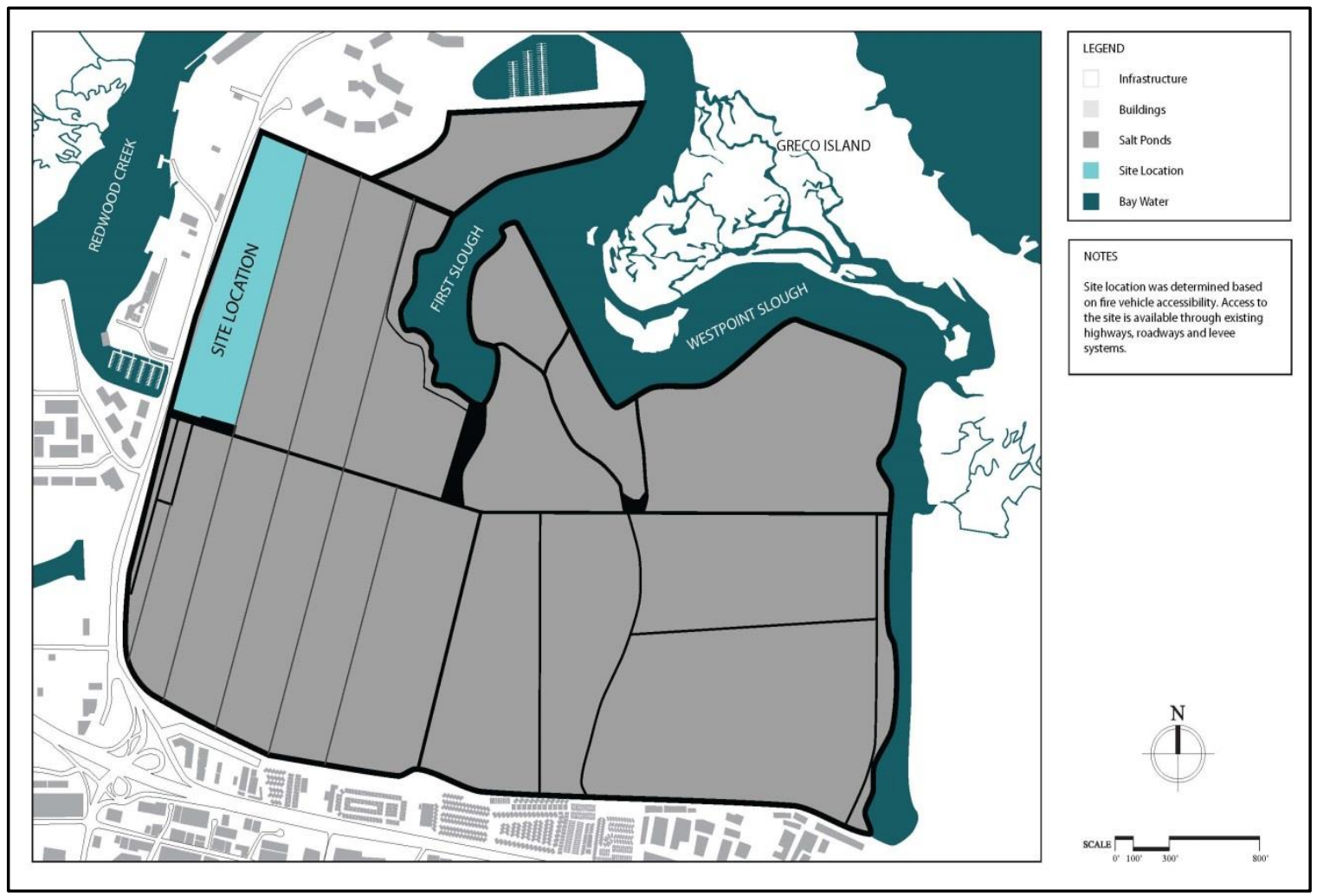

Figure 27 : Site Location in Cargill Salt Ponds

Page 43 
park and the Westpoint Slough Marina and the north by Westpoint Slough. (Figure 27) North of Westpoint Slough is Greco Island, part of the Don Edwards San Francisco Bay National Wildlife Refuge. On the east the Plant Site is bounded by Flood Slough, with a park and some light industry beyond the Slough. To the South, it is bounded by industrial uses and mobile-home parks, and on the west the Plant Site is bounded by Seaport Boulevard, the Union Pacific Railroad, and mixed industrial and commercial uses. The land is currently owned by Cargill, an agribusiness that harvests salt from the urban reserve.

\subsection{History of the Salt Ponds}

Commercial production of salt began in 1854, when Captain John Johnson settled at Mount Eden and established the first commercial solar evaporation process in the Bay. (Salt, 1997) Other settlers went into the salt production business in the Bay, totaling to 18 companies. However the 18 companies merged into one company, Leslie Salt, due to the Great Depression. By the 1950s, Leslie Salt had created 10,000 acres of salt ponds, extending to the North and South Bay areas.

In the South Bay, five salt plants produce salt through solar evaporation, a process that takes several years to complete. By water enters the ponds through intake pumps or tide gates. Once in the system, the water is called "brine." The brine moves through the ponds by a combination of gravity flows and pumping. In a series of eight evaporator ponds, the volume of the brine reduces nearly 70 percent while salinity increases. In the last stage of production, the common salt precipitates out of the pond, leaving behind a saline liquid by-product known as "bittern." Because of its high salinity, bittern is toxic to 
aquatic wildlife and cannot be discharged into the bay. Instead, the bittern is stored prior to sale for dust suppressant and de-icing products or mixed with Bay water and sent back to the ponds for harvest.

\subsection{Salt Pond Levee System}

The intake pond, like all salt ponds, is surrounded by low-lying levees, or walls of dirt that separate it from the Bay and other ponds. (Figure 28). These levees, which trace historic property lines and shoreline features, have shaped the baylands for more than 100 years. Most were built in the late 1800s to reclaim marshland for agriculture and then salt making. Today, they're maintained by the wooden dredge, the Mallard II. The Mallard II has plied San Francisco Bay's salt ponds since her keel was laid in 1936. The crew of the Mallard II works year-round, maintaining about 10 miles of our 80 miles of levees per
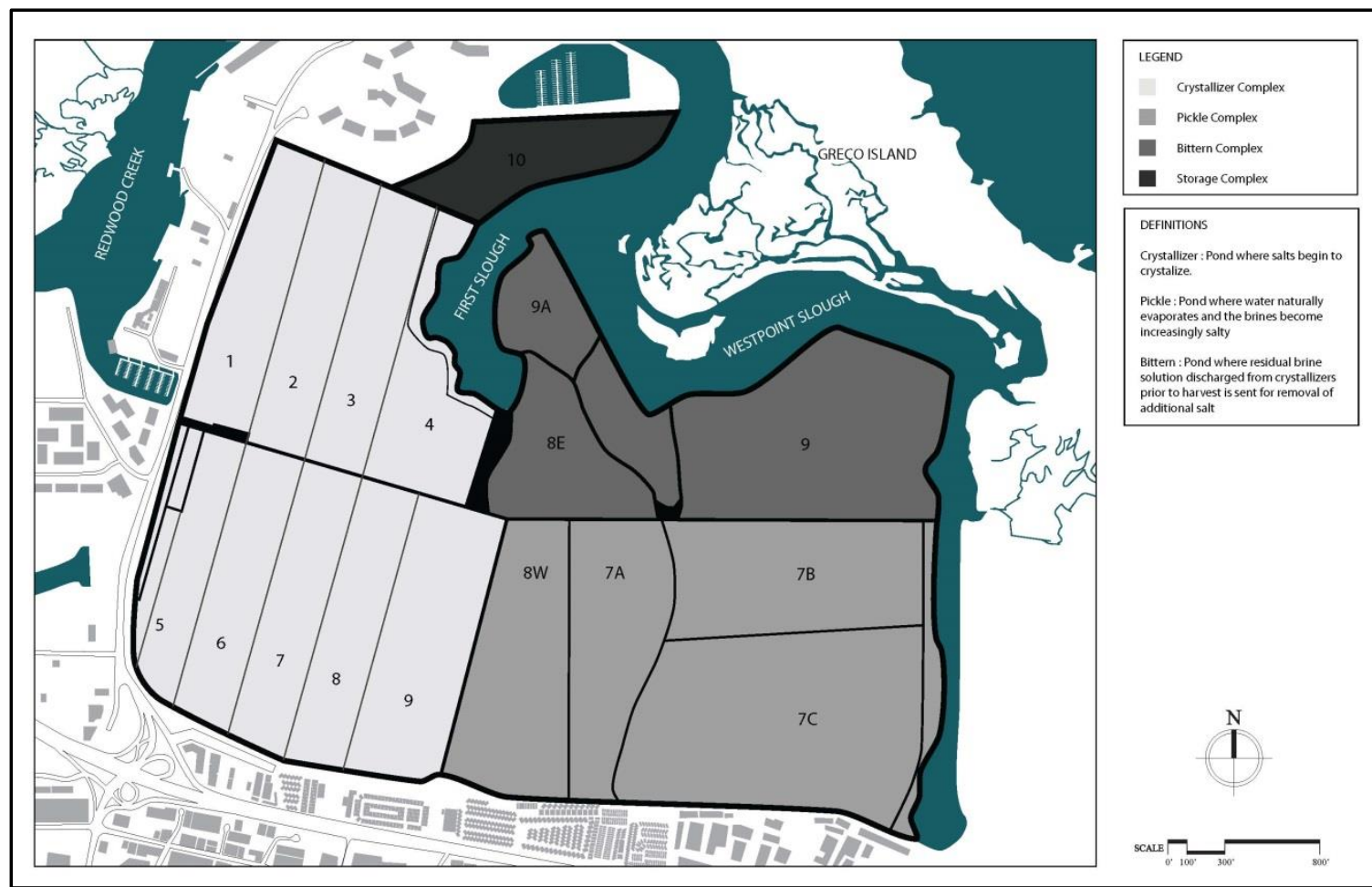

Figure 28: Map of Cargill Salt Ponds

Page 45 
year. Sediment removed from borrow ditches was originally used to construct the salt pond levee system, and levee maintenance activities over decades have continued to mine sediment from these ditches. For this reason, borrow ditches up to 200 feet wide run alongside most salt pond levees. Anchored on the spuds, or stabilizing legs, the dredge scoops mud in the clam-shell bucket from borrow ditches alongside the salt ponds, and places it atop the levees. Borrow ditches can affect the outcome of restoration efforts. The most significant concern is the decreasing ability of borrow ditches to provide material for ongoing levee maintenance. While this need will decline as marsh restoration occurs, some ongoing levee maintenance will always be needed, especially near ponds retained as open water areas.

\subsection{Tides in Redwood City}

Most of the waves in the South San Francisco Bay are locally generated windwaves as opposed to swell propagating from the open ocean. The wind direction over the South Bay is typically from the west to northwest in the late spring, summer, and early fall with more variable conditions in winter (Cheng and Gartner 1985). On an annual basis, the greatest tides occur in July and December and the smallest tides occur in April and October.

On average, the lowest tide level within the salt ponds is below 0 '- 0 " and the highest is $8^{\prime}-0$ " from the pond bottom, however the highest observed water level has remained at 9'-6" from the pond bottom or approximately 12 ' -0 " from a 0 '-0" elevation.

(Table 3) Currently, the mean tide level on an average day is approximately 5'-3" from a 
0'-0" elevation (Figure 29), however the predicted mean tide level will increase to 6'-0" in 2014 (Figure 30) and is predicted to rise to 9'-5" in 2100. (Figure 30)

Although the city has not experienced extreme flooding, the USACE has predicted that a 100 year flood will produce an estimated tide of $11^{\prime}-0$ " from the pond bottom (13'-6" from a 0'-0" elevation) an a 500 year flood will produce an estimated tide of 11'-2" (13'-8" from a 0'-0" elevation). (Table 3)

\section{Table 3 Cargill Salt Pond Tidal Benchmarks}

\begin{tabular}{|l|l|l|}
\hline Cargill Salt Pond Tidal Benchmarks & Redwood Creek & Westpoint Slough \\
\hline 500 -year Estimated Tide (USACE) & $11^{\prime}-2^{\prime \prime}$ & $11^{\prime}-4^{\prime \prime}$ \\
\hline 100 -year Estimated Tide (USACE) & $11^{\prime}-0^{\prime \prime}$ & $11^{\prime}-1^{\prime \prime}$ \\
\hline Highest Observed Water Level & $9^{\prime}-6^{\prime \prime}$ & $9^{\prime}-8^{\prime \prime}$ \\
\hline Mean Higher High Water (MHHW) & $8^{\prime}-0^{\prime \prime}$ & $8^{\prime}-0^{\prime \prime}$ \\
\hline Mean High Water (MHW) & $7^{\prime}-4^{\prime \prime}$ & $7^{\prime}-4^{\prime \prime}$ \\
\hline Mean Tide Level (MTL) & $4^{\prime}-3^{\prime \prime}$ & $4^{\prime}-3^{\prime \prime}$ \\
\hline Mean Low Water (MLW) & $1^{\prime}-2^{\prime \prime}$ & $1^{\prime}-2^{\prime \prime}$ \\
\hline Mean Lower Low Water (MLLW) & $0^{\prime}-0^{\prime \prime}$ & $0^{\prime}-0^{\prime \prime}$ \\
\hline
\end{tabular}

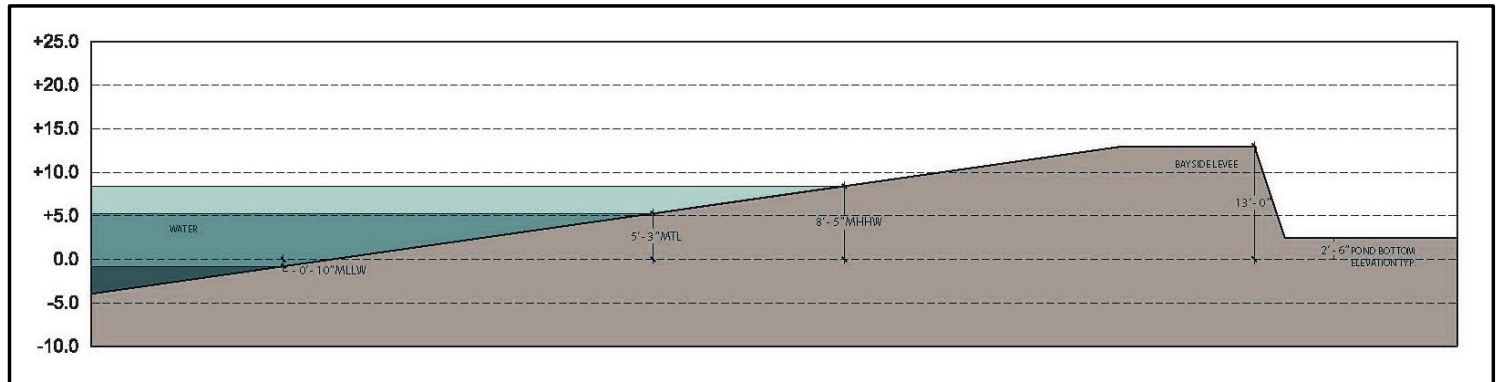

Figure 29: High \& Low Tides in 2013

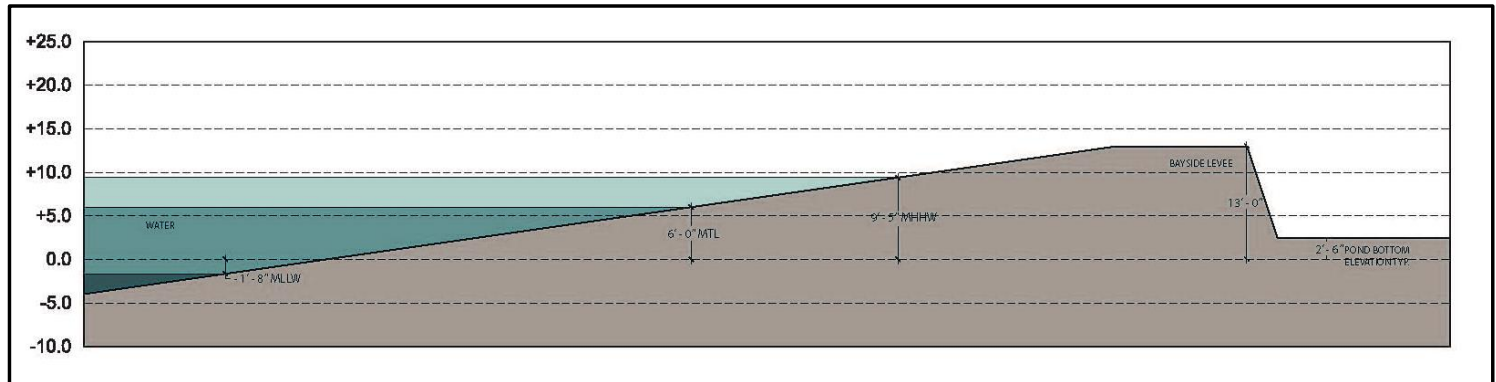

Figure 30: Predicted High \& Low Tides in 2014 
As the tides propagate from the Pacific Ocean into the San Francisco Bay, the enclosed nature of the bay creates a mix of progressive wave and standing wave behavior, wherein the wave is reflected back upon itself, hence increasing the tidal amplitude. In addition, coastal flooding can result from exceptionally high astronomical tides, increased by storm surge and wind wave action. Storm surge refers to the increased elevation of water levels due to meteorological conditions and result from atmospheric disturbances characterized by low pressures and high winds and produce a short-term rise in water elevation. When a storm coincides with a spring high tide, the resulting increase in water elevation can be significantly larger than just the storm surge alone. Weather events such as an El Niño can produce a substantial difference in water levels. Tidal data conducted by Pacific Institute have recorded water levels in the bay to be raised 1 to 2 feet higher than average during an El Niño event and persisted for several months.

FEMA has been studying the system of levees that protect areas in Redwood City from the sea. The city has historically experienced mild flooding in the areas near Cordilleras Creek and the Friendly Acres neighborhoods southeast of Woodside Road, both areas identified in the 500-year floodplain. Redwood Shores is also located in the 100-year floodplain and has experienced mild coastal flooding from the San Francisco Bay. Levee heights around Redwood Shores were constructed to withstand a 100-year high tide, however the crests of some levees are at, or a few tenths of a foot lower than, the 100-year tide elevation based on current climate patterns. (Redwood City General Plan, PS-30) Provided that the levees do not overtop, Redwood City predicts that any flooding would be shallow. Yet climate change in the San Francisco Bay has yielded 
higher levels of sea water along the coasts, posing the threat of inundation to residents and infrastructure in the event of a storm surge. While the levees currently provide moderate protection from the bay's rising waters, it is predicted by BCDC that the levees will be breached by the bay in the year 2100 and that inundation of residences and critical infrastructure is inevitable. (Figure $33 \& 34$ )

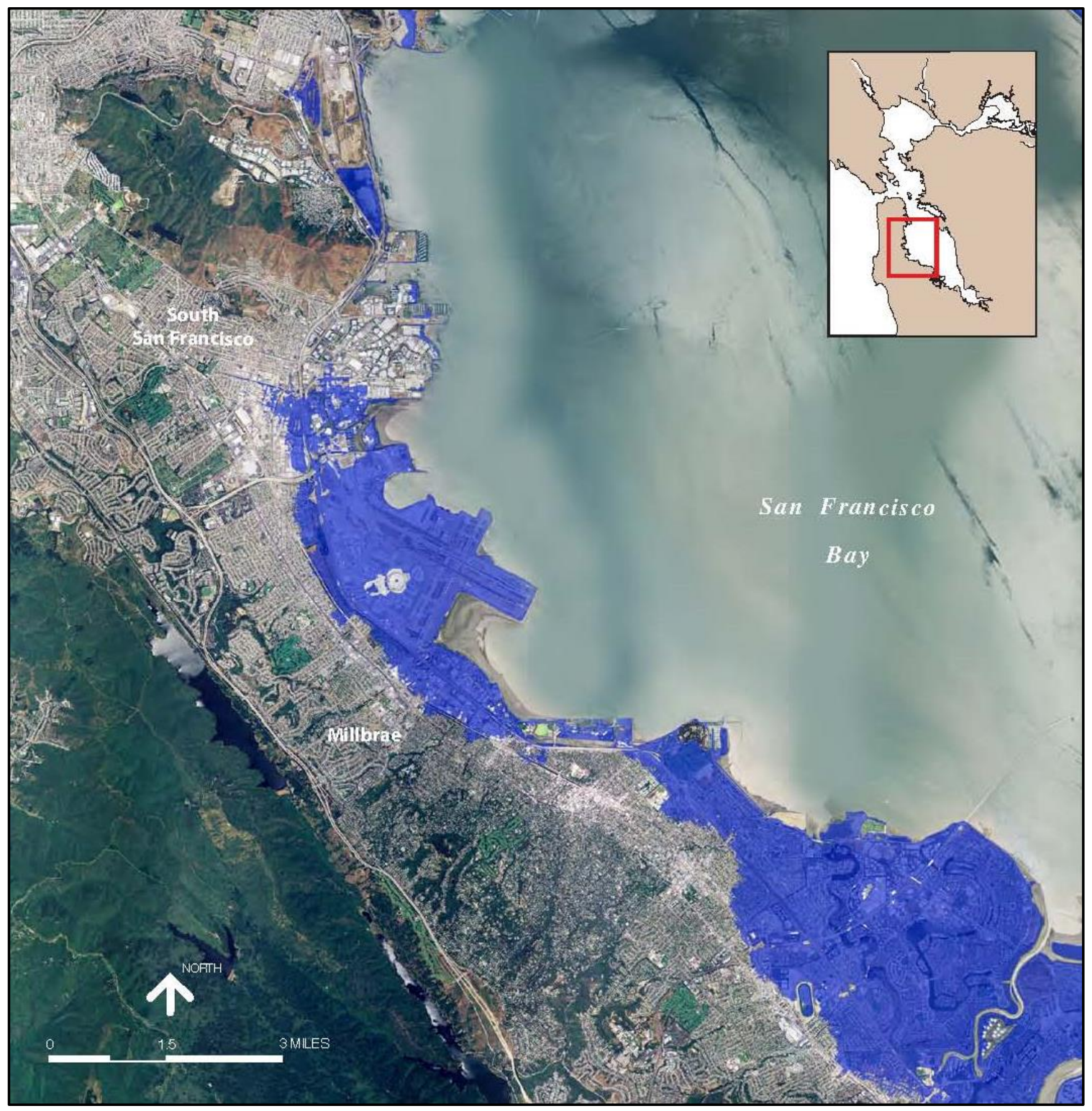

Figure 31: Predicted Sea Level Rise in Redwood City in 2100 


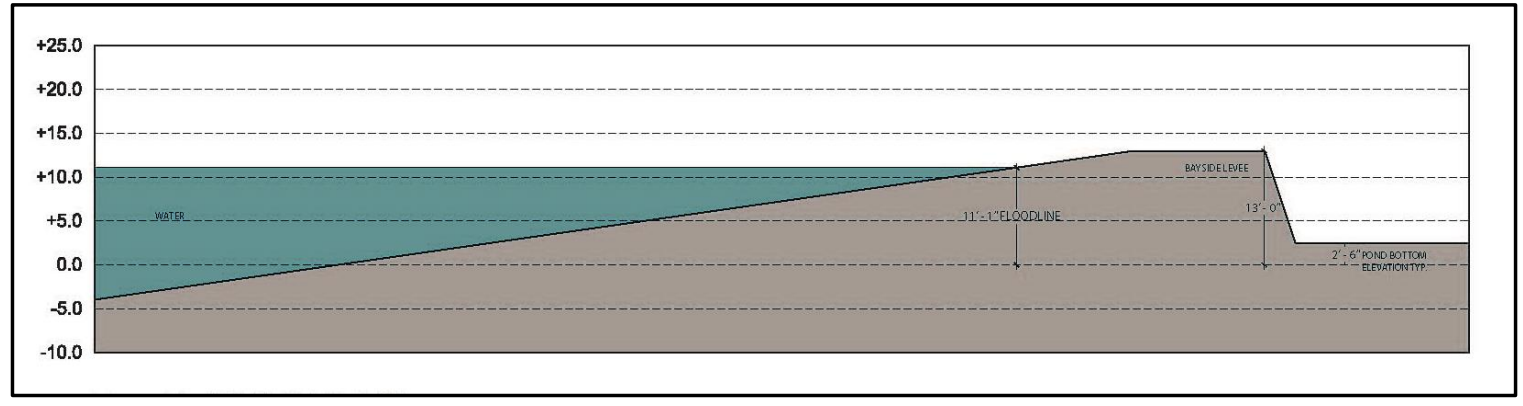

Figure 32 : 100 year Flood Level

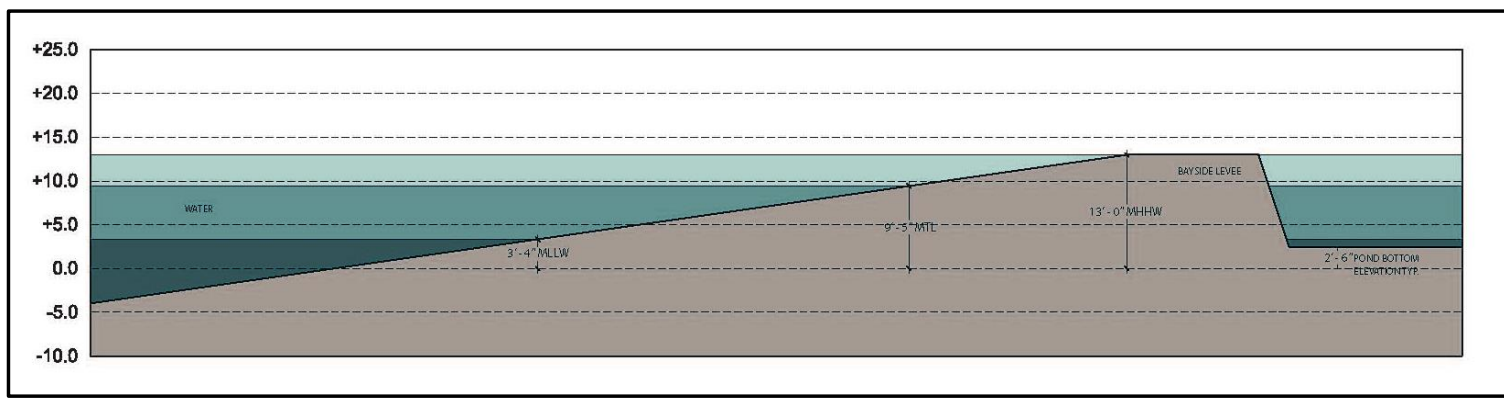

Figure 33: Predicted High \& Low Tide Levels in 2100

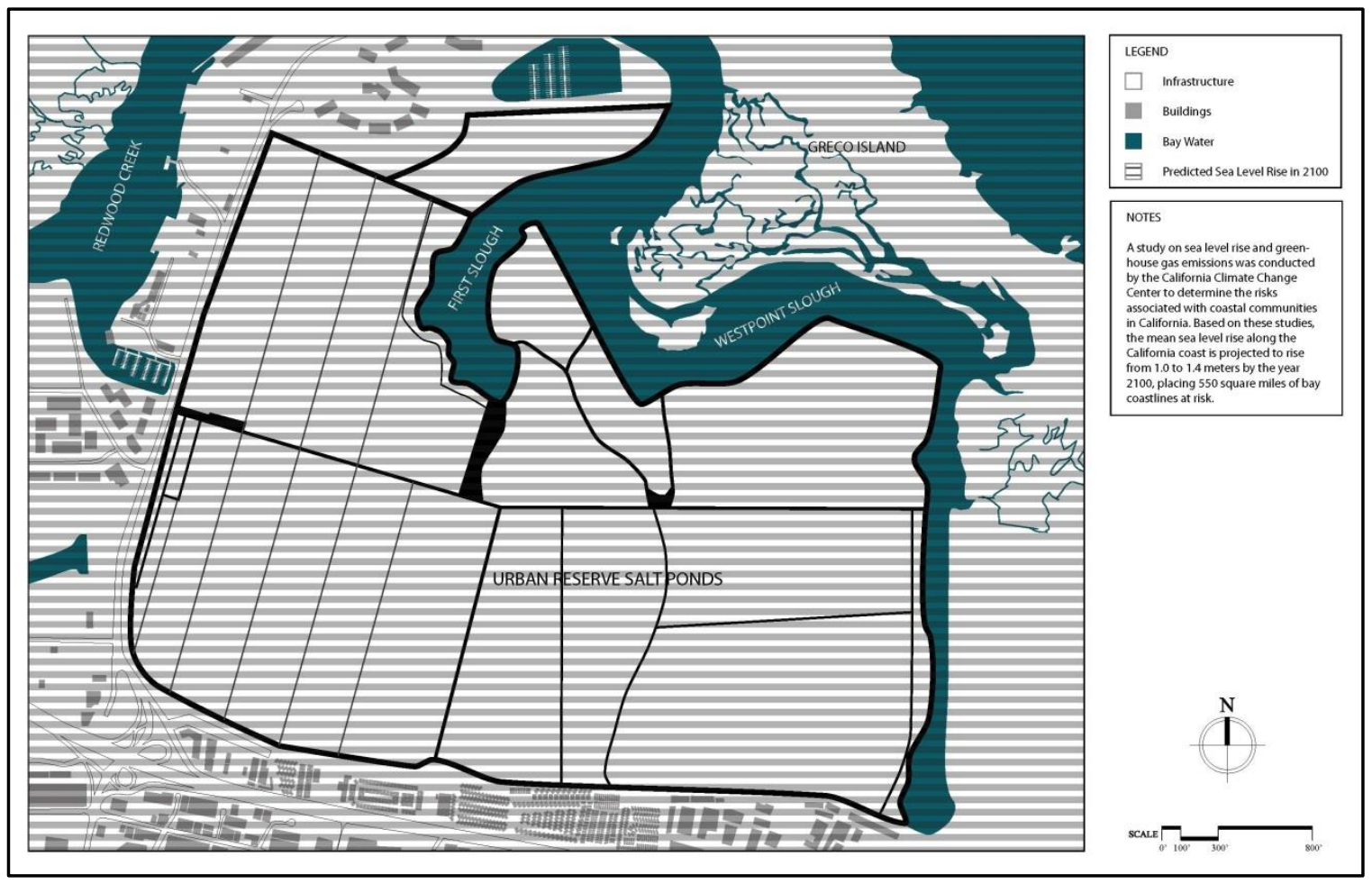

Figure 34 : Map of Predicted Inundation in Cargill Salt Ponds in 2100 


\subsection{Restoring Additional Salt Ponds}

Salt ponds no longer needed for salt production or city development offer a significant opportunity for the restoration of large areas of the former Bay to tidal action. The breaching of salt pond levees has the potential to increase water quality, reconnect existing subtidal areas with the bay to increase resting, foraging and breeding opportunities for wildlife, and support the establishment of a protected tidal flat. (bcdc.ca.gov) Due to the high salinity of the ponds, there is little aquatic life to be found and is primarily limited to brine shrimp and brine flies, although some invertebrates and marine microalgae can be found in the low salinity ponds. Birds such as grebes, gulls, sandpipers and phalaropes can be found around the ponds however the area is primarily used for roosting, not foraging. Dry areas, levees and internal islands can provide breeding habitat for birds such as the Western snowy plover and American Avocet. Once desalinated and the ponds are merged with the bay, they will have the potential to carry coastal species of wild life and plants, such as sea lettuce; invertebrates, such as crabs; fish, such as bay pipefish; and waterbirds, such as American White pelicans, California least terns and numerous wintering waterfowl. (bcdc.ca.gov) There is an increasing recognition of the importance of the habitat and wildlife within the salt ponds and careful steps should be taken to ensure the minimal disruption of these ecosystems. 


\section{Chapter 5}

\section{Project House}

\subsection{House Goals}

This project will develop an appropriate design solution for an amphibious house in the Redwood City urban reserve based on the gradual rise in sea level that is predicted by FEMA. Solutions will include waterproof materials and the protection of vital utilities, a structural sub-frame that acts as the buoy, and vertical guidance poles attached to the barge that provide resistance to lateral forces from wind and water.

Based on the demographics in Redwood City, the average owner occupied household size is approximately 3.25 persons per unit. Household income is oftentimes the crucial factor in evaluating the size and type of housing that can be procured by any given household. Moreover, overall employment in the city affects housing demand, because as employment levels increase in Redwood City and nearby communities, a percentage of the workforce will desire to live within Redwood City rather than commute. With about three persons per household, this project will be a single-family unit no more than 2,000 square feet of living space and should cost less than the mean purchase price of a home in Redwood City (approximately \$808,600).

The house will be the equal of traditional houses on land, including comfort, quality and price. Comfort can be defined as meeting the same building requirements imposed on static houses including structural stability. Materials and maintenance are 
equivalent to a house built on land and it should have the same lifespan as a static house, with the only difference being the foundation system.

\subsection{House Concept}

Permeability can be defined as the state of a material that allows liquids or gases to pass through it. The concept of permeability can be attributed to the surrounding salt flat environment where water must pass through small and large openings in the levee systems in order to circulate.

Permeability was accomplished in three ways: First, by creating recesses of building mass; Second, by creating protrusions of building mass; Third, by distributing windows of various shape and size on the elevations. A permeable morphology would produce positive effects at a building scale, i.e. better air and light circulation, accessibility and visibility, and communication between interior and exterior spaces.

\section{Examples of Permeability}

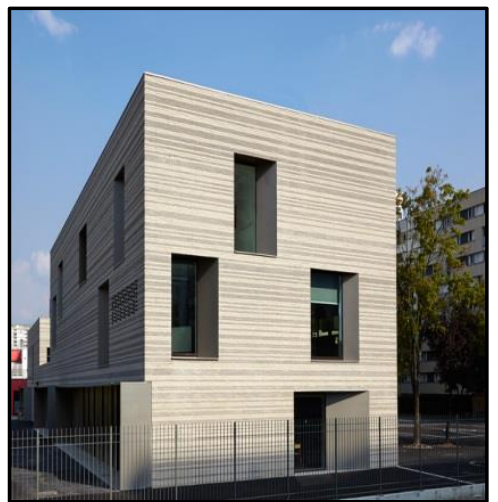

Figure 35: Recessed Mass

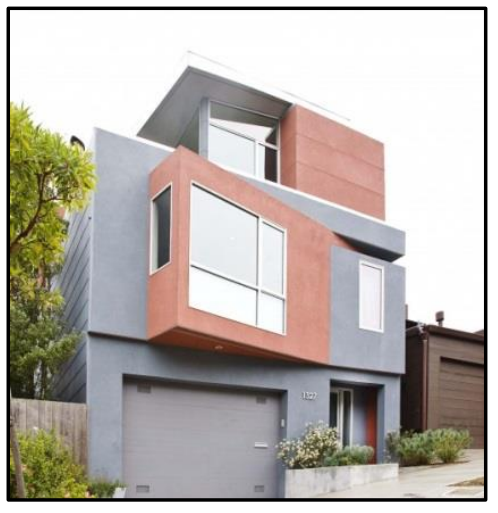

Figure 36 : Protruding Mass

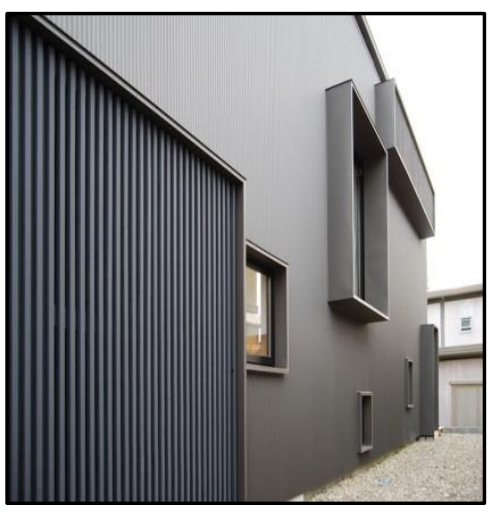

Figure 37 : Varying Window Types 


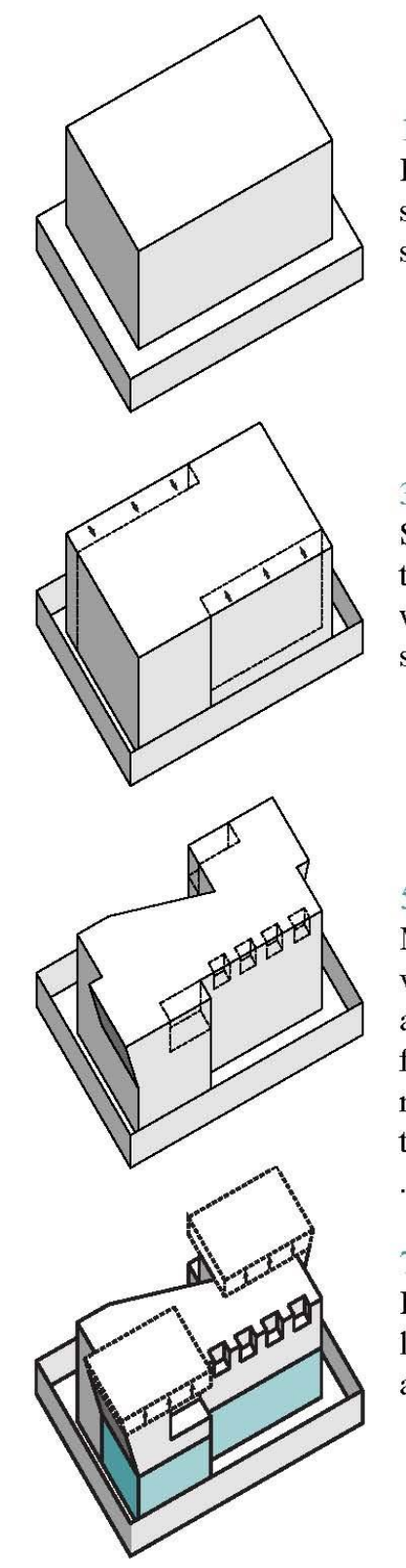

Begin with solid symmetrical shapes for stability.

3.

Subtract from soild form to create interior spaces while maintaining symmetry.

5.

Multiple windows of various shapes and sizes are distributed on the facades to produce multiple parametric voids through subtraction

7.

Extrude various roof lines for added architectural interest.

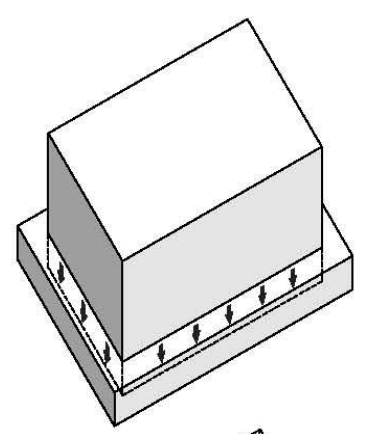

2.

Subtract volume from base shape to create a barge. The large solid shape is then vertically lowered into the barge.

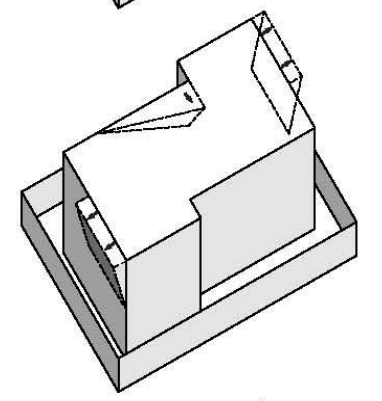

4.

Subtract angled solids while adding protrusions of angled solids elsewhere. This allows sunlight into spaces while minimizing it elsewhere.

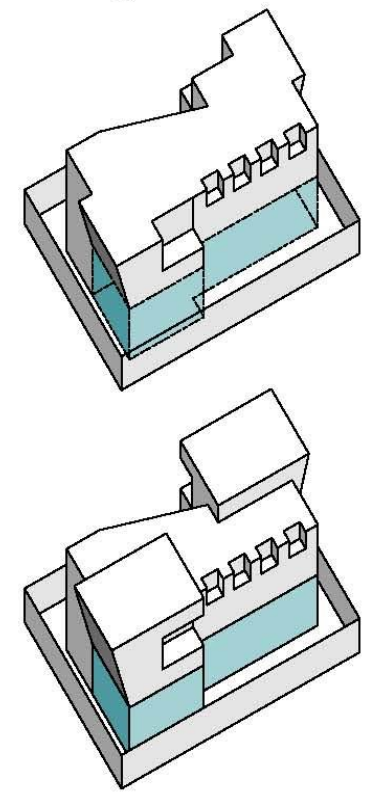

6.

Horizontal permeability exposes more interior surfaces to the exterior and creates expansice views with glass windows.

8.

The result is a symmetrical house with open spaces, recessed building mass, protruding building mass with numerous windows. 


\subsection{Project Description}

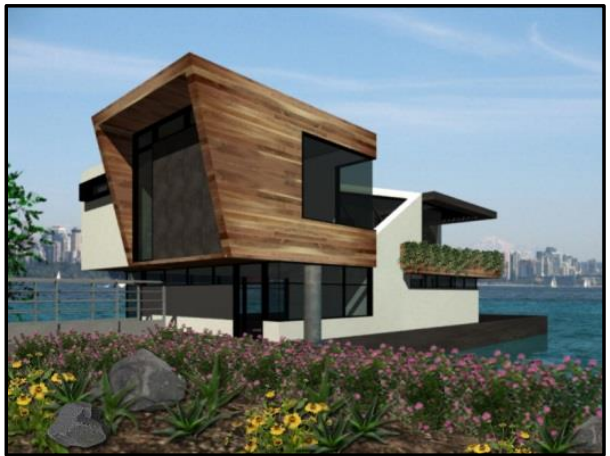

Water Type: Salt Water

House Type: Amphibious

Buoyancy Materials: Steel Barge w/ EPS Blocks

Size of House: $1,785 \mathrm{ft}^{2}$

Size of Barge: $1,589 \mathrm{ft}^{2}$

2 bedrooms, 2.5 bathrooms

Figure 39: Exterior Perspective

The house is made out of timber and sits within a steel barge. The reason for timber construction is that wood is a light building material. A steel barge is used due to its low corrosive rate in salt water and is not harmful to the water on which it floats. Leachable metals, such as zinc, lead and copper cannot be used because of the pollutants they release as soon as they come into contact with the water. To ensure necessary ballast and waterproofing, concrete slabs are inserted on top of Expanded Polyeurethane Foam blocks inside the barge. The wooden structure on a concrete foundation within a steel barge gives the house a low center of gravity, which promotes stability. In addition, spaces were arranged symmetrically to promote added ballast. (Figure 40)

To keep the houses in place, they have all been connected to two steel mooring poles, by means of a fixed connection. The construction allows houses to move up and down with the water level. The mooring poles are positioned diagonally at opposing sides of the house, giving the greatest stability and lease amount of lateral movement. (Figure 41) 


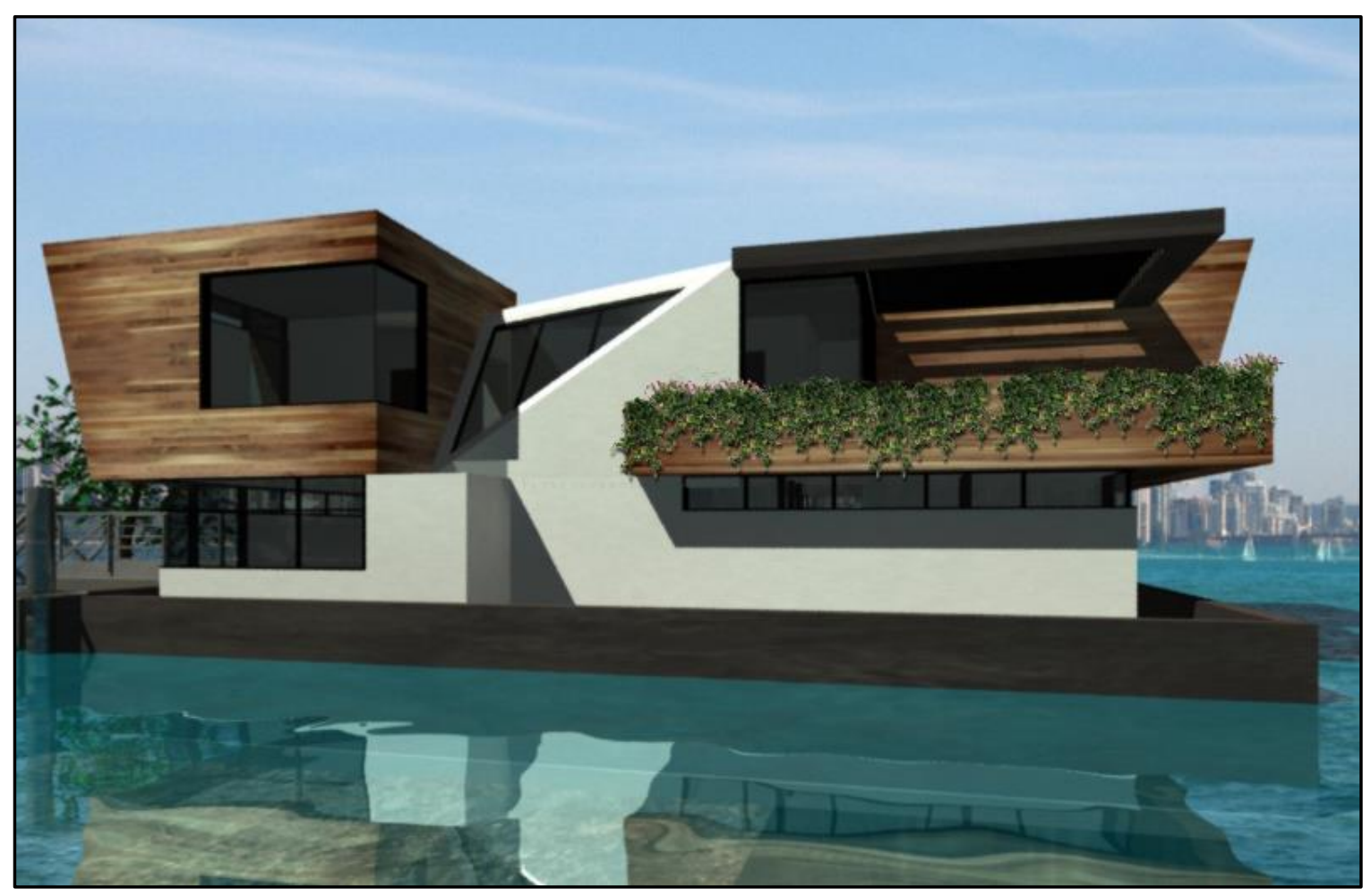

Figure 40: Exterior Perspective

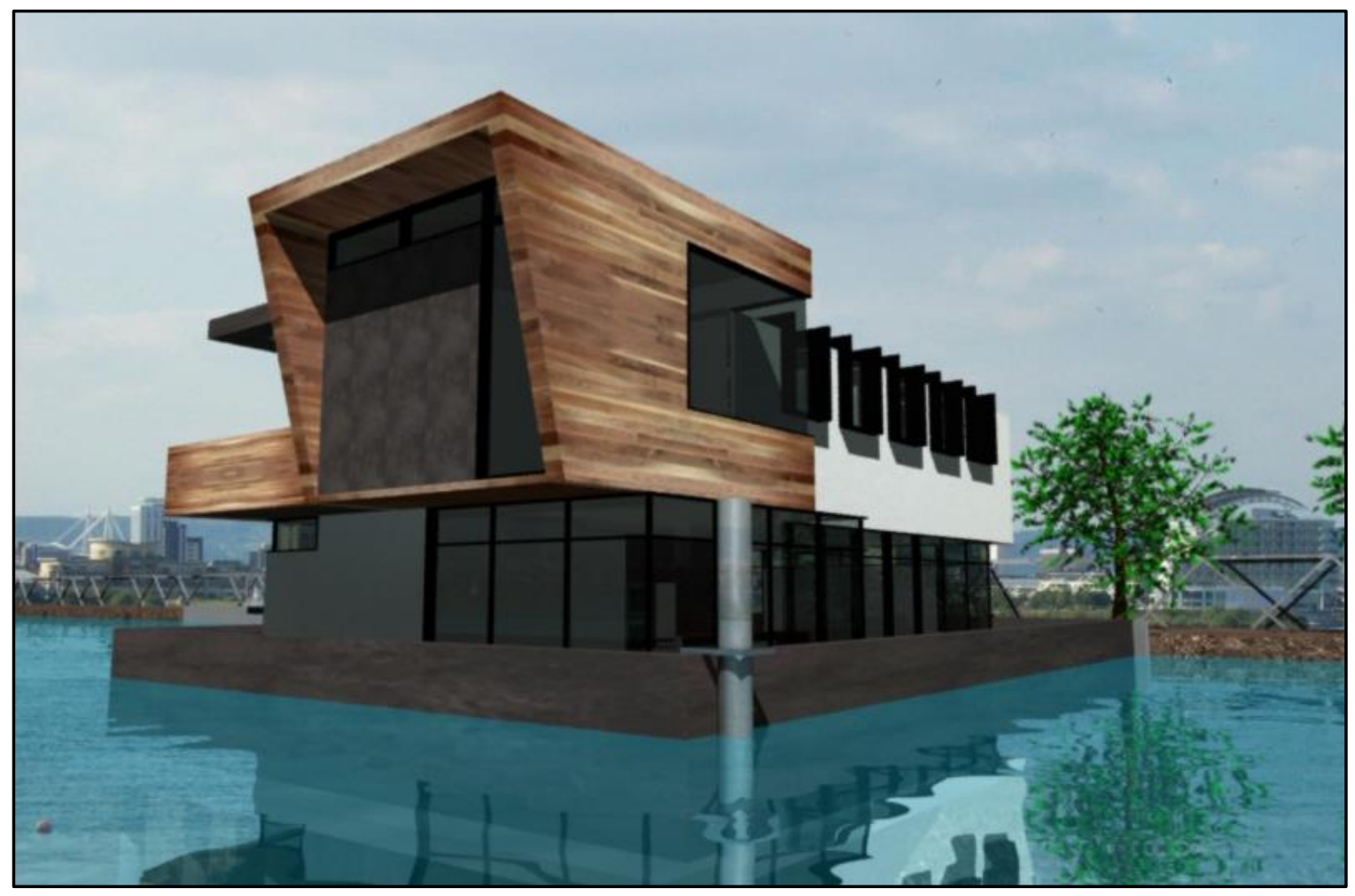

Figure 41 : Exterior Perspective

Page 56 
Residents enter the house from the entrance ramp. A series of steps are located in front of the entrance ramp on top the deck that takes residents to the front door. Once inside, residents will notice the foyer floor is raised to the same height of the exterior deck, causing the space to appear smaller at the entrance. However, once residents descend 18 inches down the steps, the interior opens up to the kitchen, dining and living room, giving the illusion of a vast space. (Figure 42)

All areas of greater weight are centrally positioned throughout the house, including the kitchen and upper level bathrooms, in order to promote added stability. The first floor is comprised of public areas, including the kitchen, dining and living room. Added storage space and a half bathroom are also located on this level. Vast windows on the first level frame the exterior scenery and allow natural light to penetrate the spaces. Larger windows are oriented towards the North-East in order to minimize interior overheating and direct sunlight from entering, while smaller windows are oriented towards the South-West to ensure enough light penetrates the house. (Figure 43)

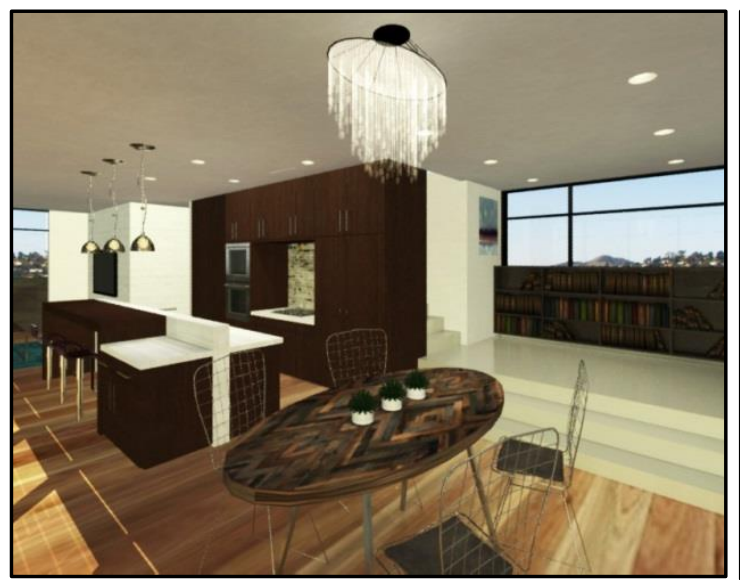

Figure 42: Dining \& Kitchen Perspective

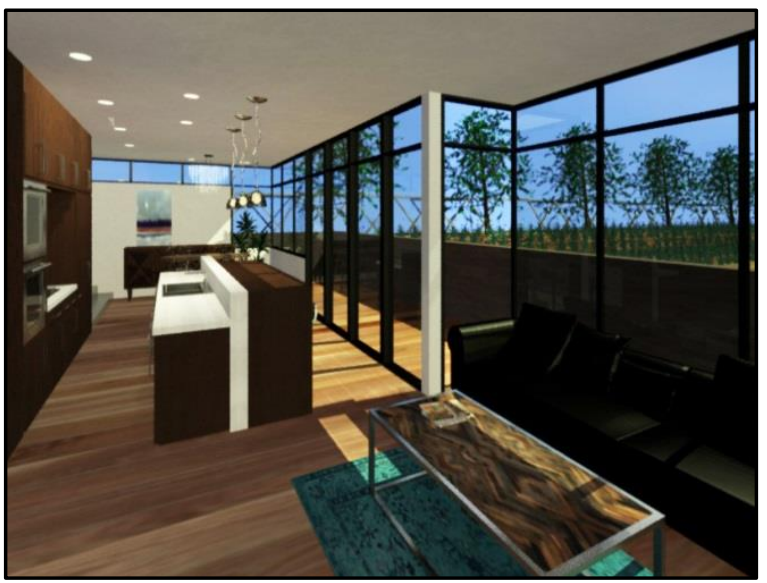

Figure 43: Living Room \& Kitchen Perspective 
The bedrooms are situated on the second level with two full bathrooms and a laundry room. Both bedrooms contain a 90 degree corner window to allow for added views as well as smaller windows for added natural lighting. (Figure 44) The master bedroom contains its own bathroom while another full bathroom is located in the hallway. A balcony extends from the top of the stairs out to the South-West corner of the house. From this vantage point one has a view out to the salt ponds and the adjacent San Francisco Bay. For this project I added planting beds into the balcony railing so that residents would have similar exterior amenities (i.e. a garden) as a traditional house.

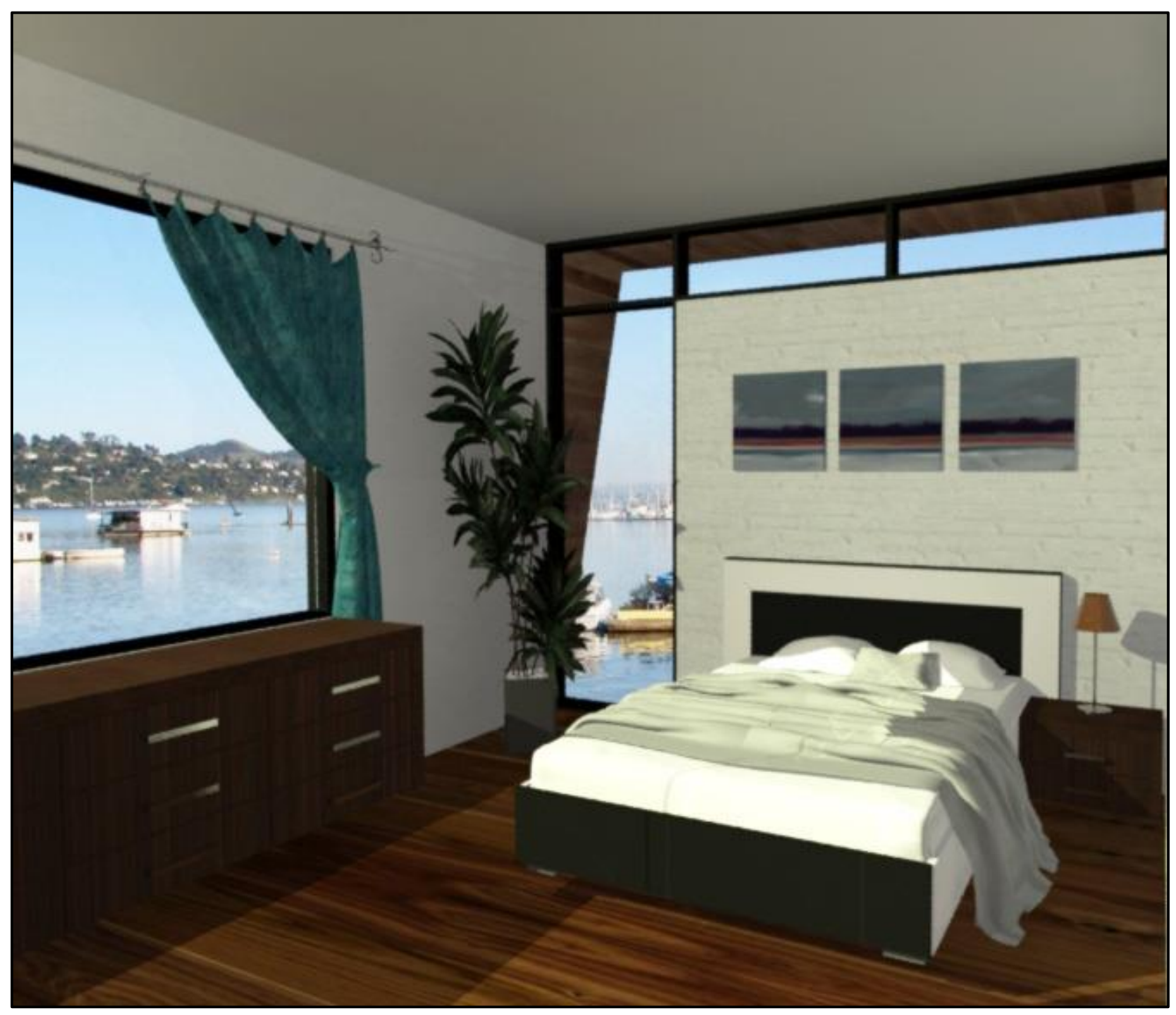

Figure 44: Bedroom Perspective 
The windows on the second level alternate in shape and size. A sloped triangular window begins at the second level and ends at the roof line in order to allow natural light to penetrate the hallways and to create architectural interest. (Figure 42) Windows along the South-West side are characterized by the addition of skylights. The skylights are oriented perpendicular to the exterior windows and form a 90 degree angle with the windows. The skylight/window is further characterized by steel angle frames that act as sunshading louvers and add architectural interest. (Figure 45)

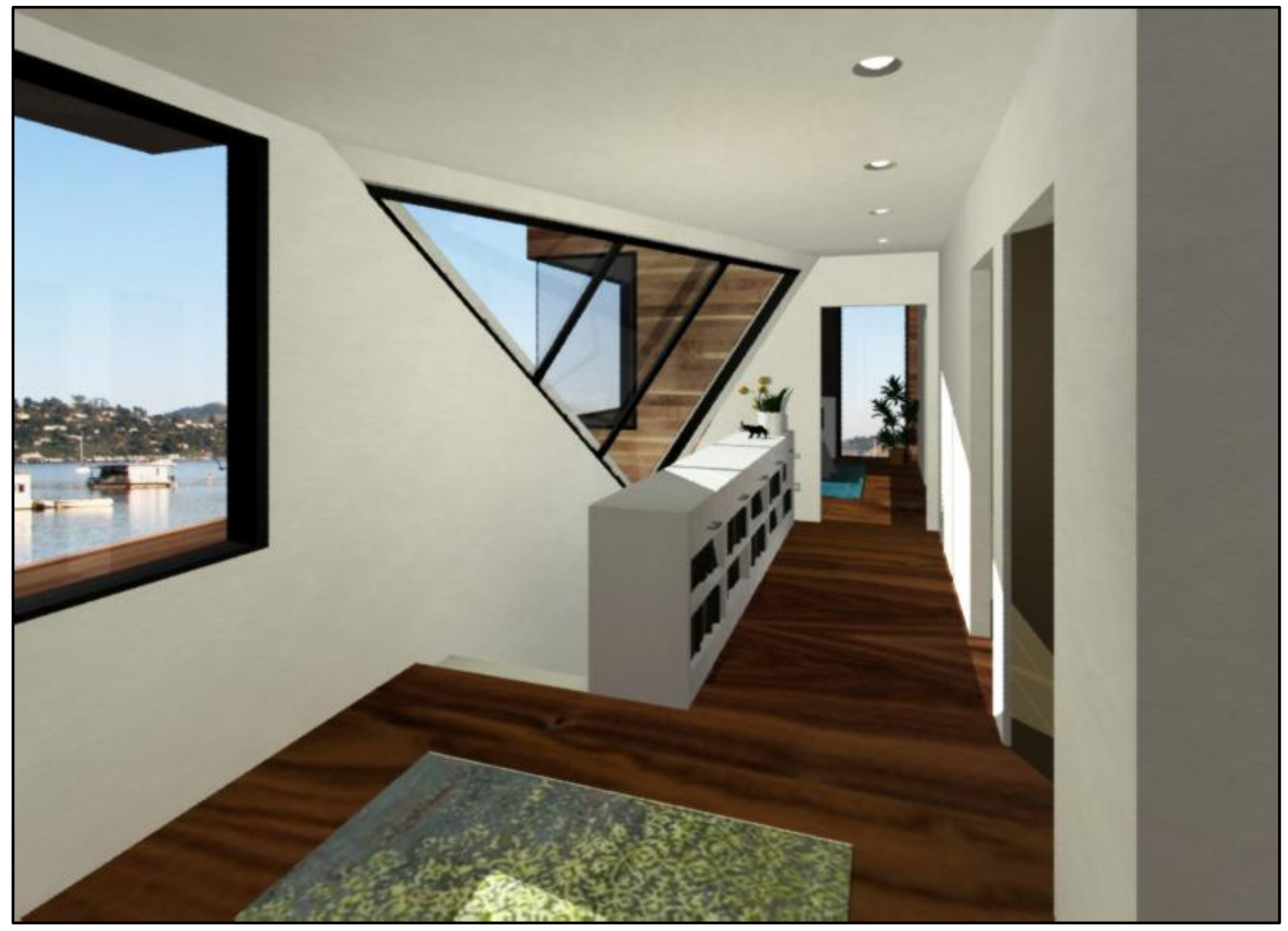

Figure 45: Interior Hallway Perspective

The exterior deck space is characterized by a wooden deck that wraps around the entire house. A 34" railing frames the deck and allows residents to be worry-free from children and pets falling into the water. A large deck adds structural stability to the home as well as added outdoor space. 


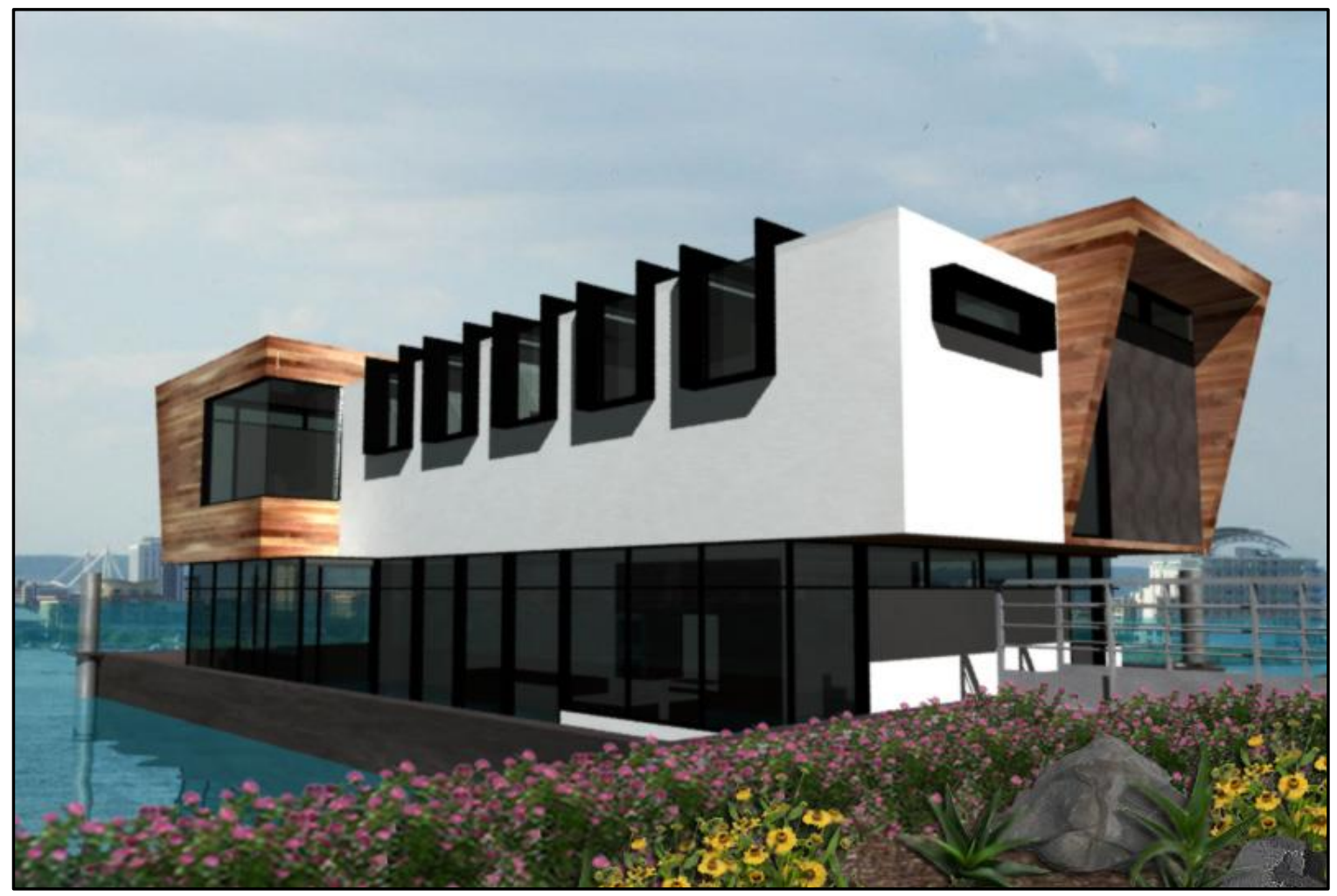

Figure 46: Exterior Perspective

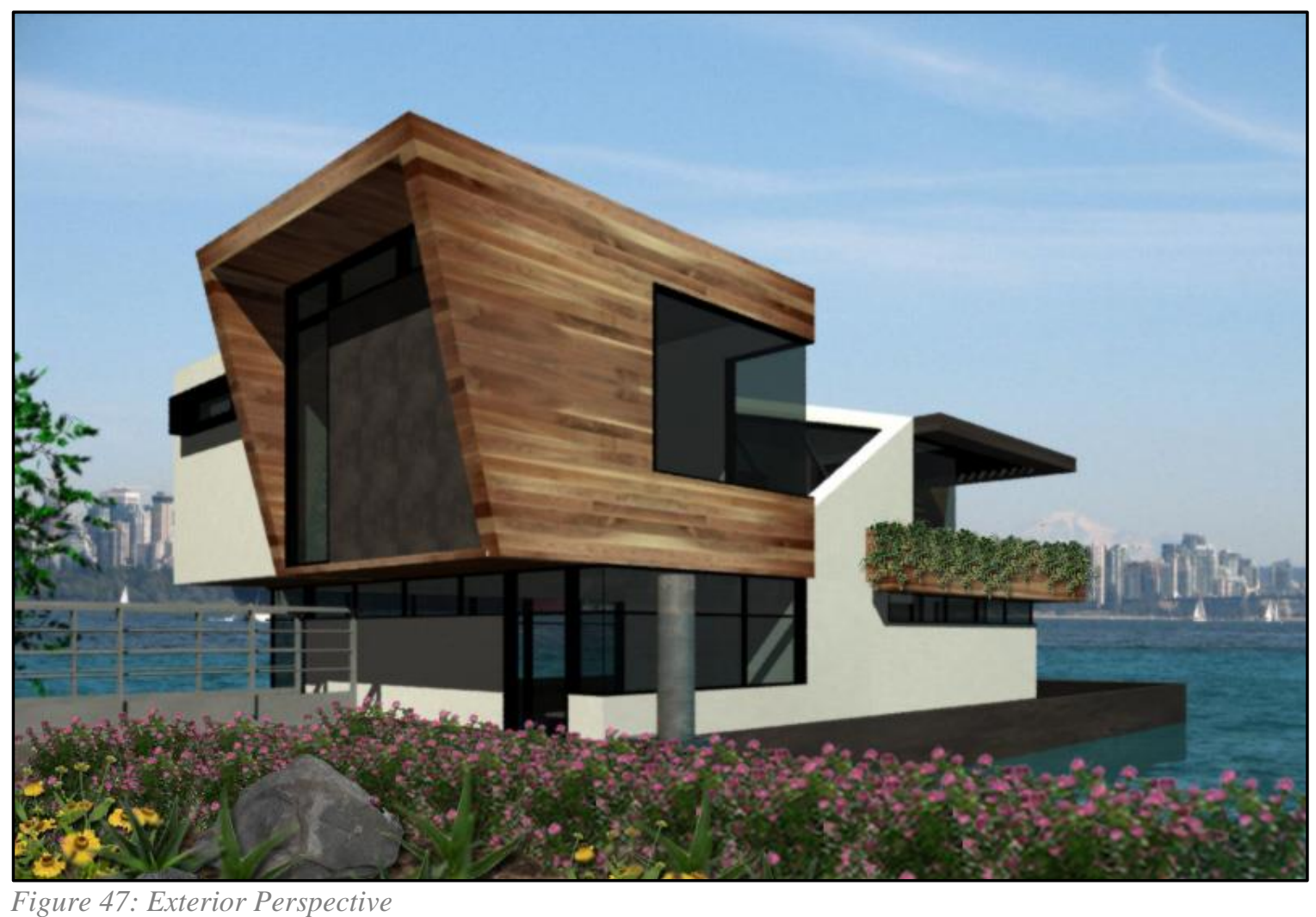

Page 60 


\subsection{Architectural Plans}

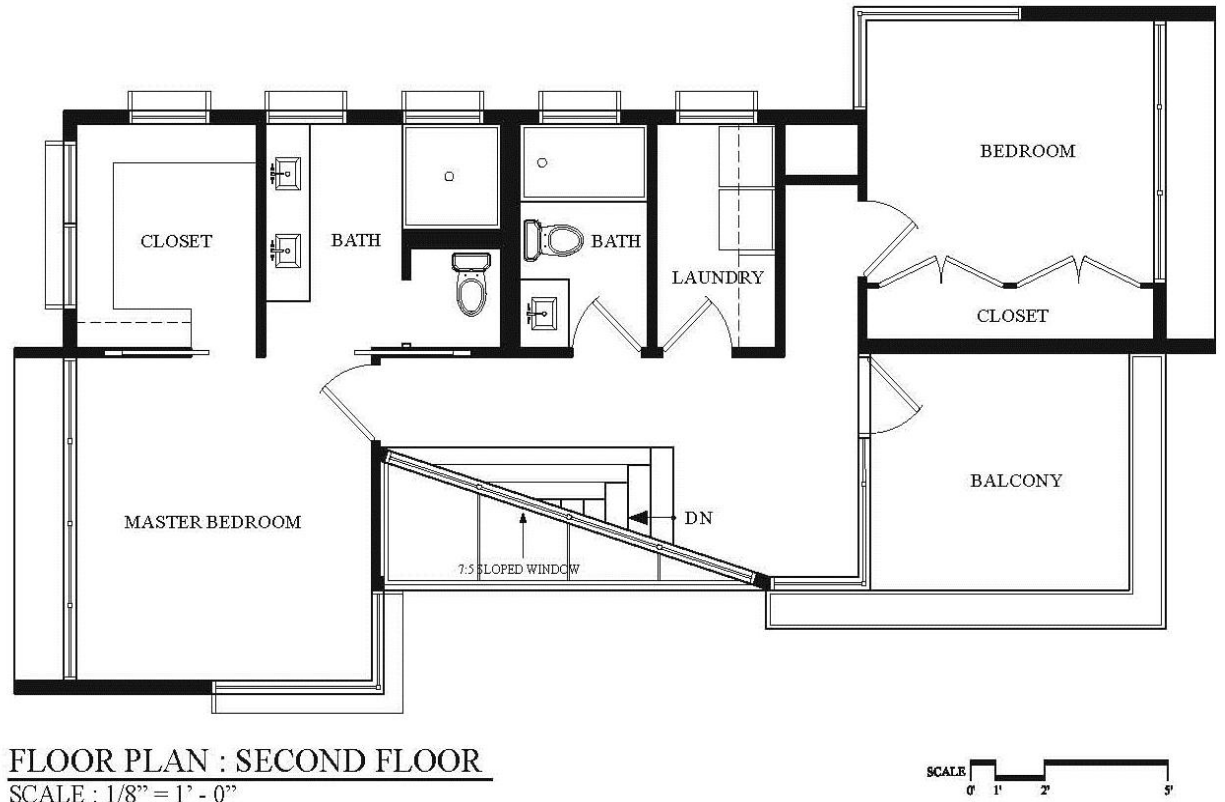

$\$ \frac{\text { FLOOR PLAN : SECOND FLOOR }}{\text { SCALE }: 1 / 8^{\prime \prime}=1^{\prime}-0^{\prime \prime}}$

POnd MOORING POST

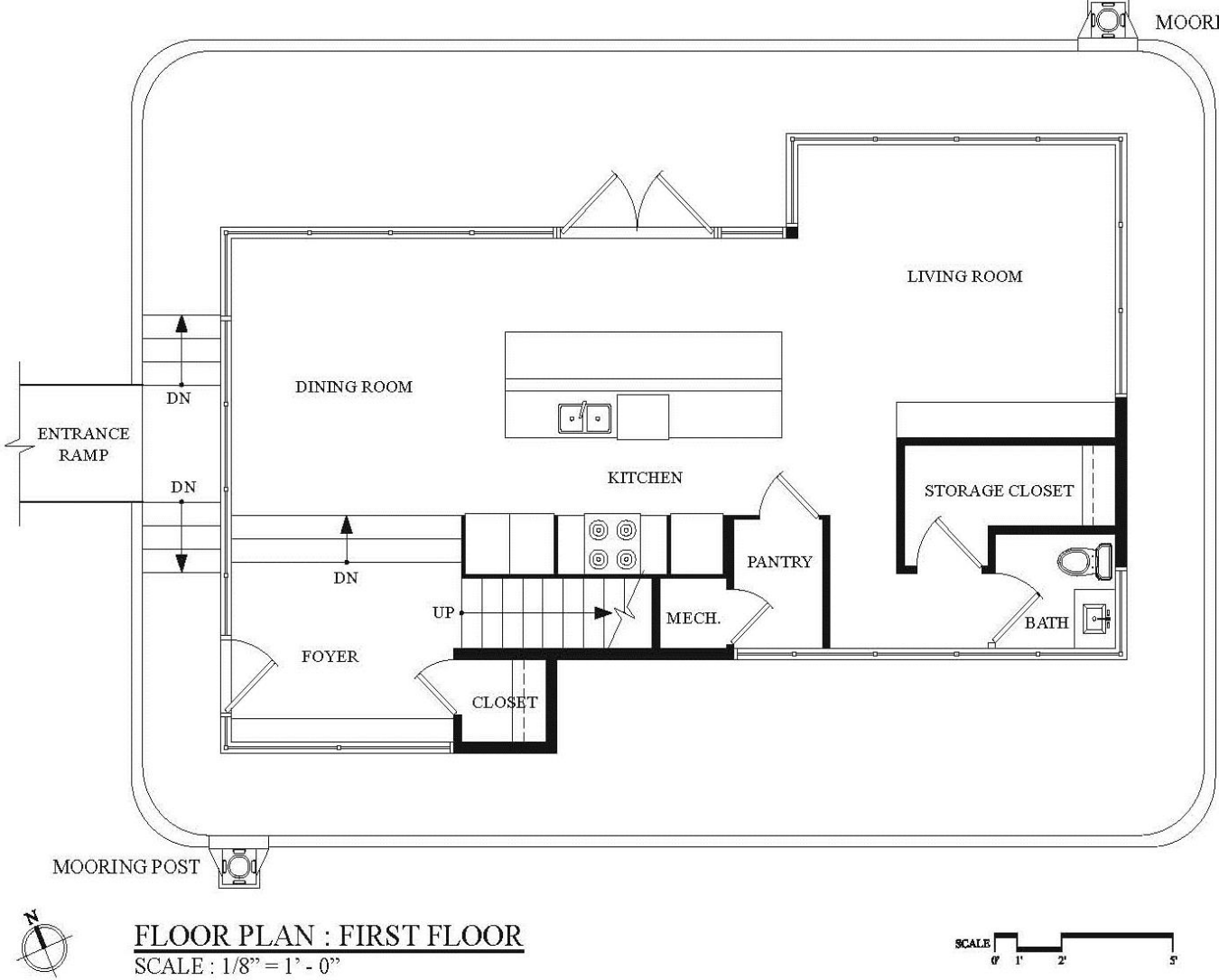

Figure 48 : First \& Second Floor Architectural Plans

Page 61 

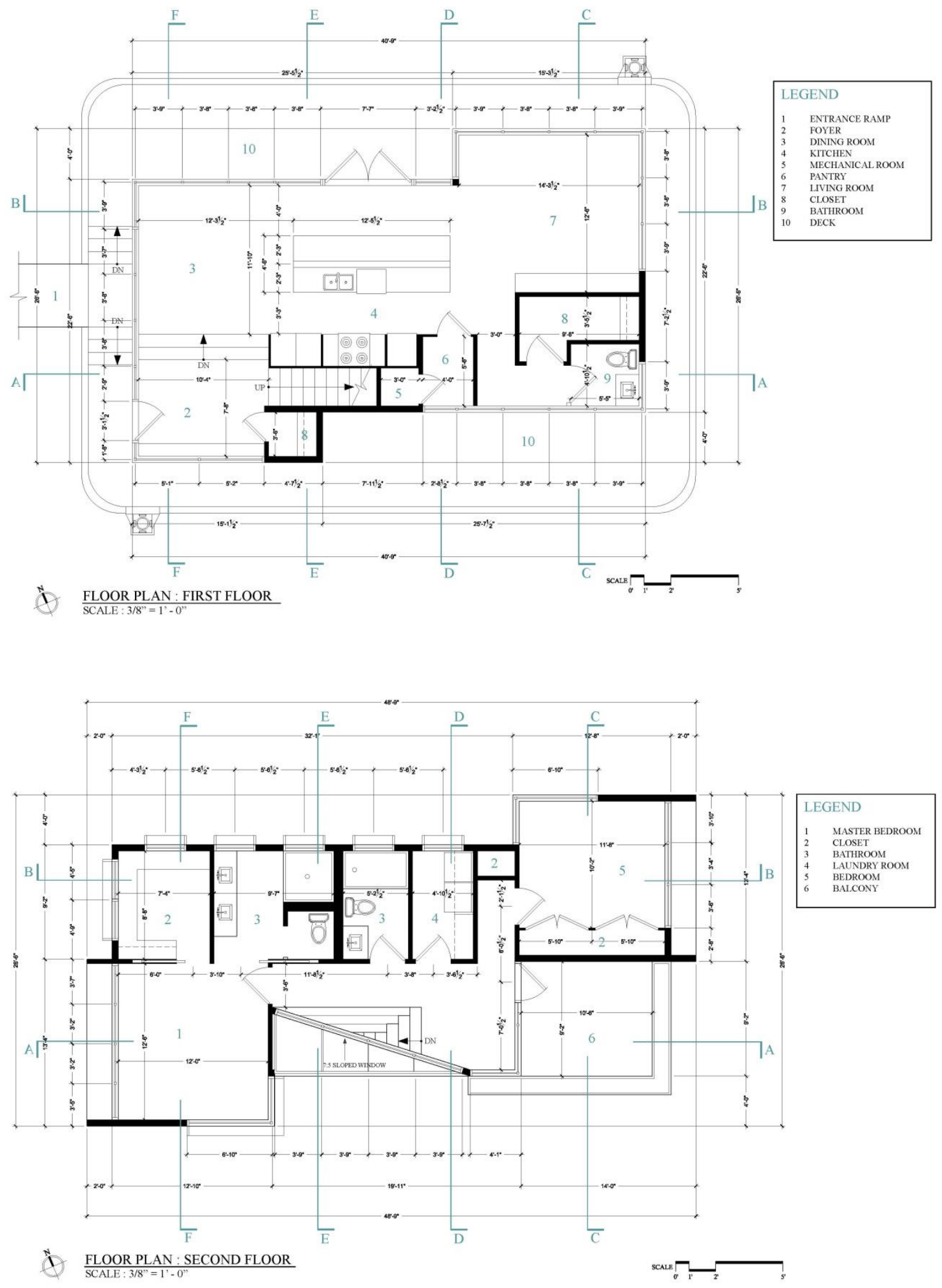

Figure 49: First \& Second Floor Dimensioned Floor Plans

Page 62 


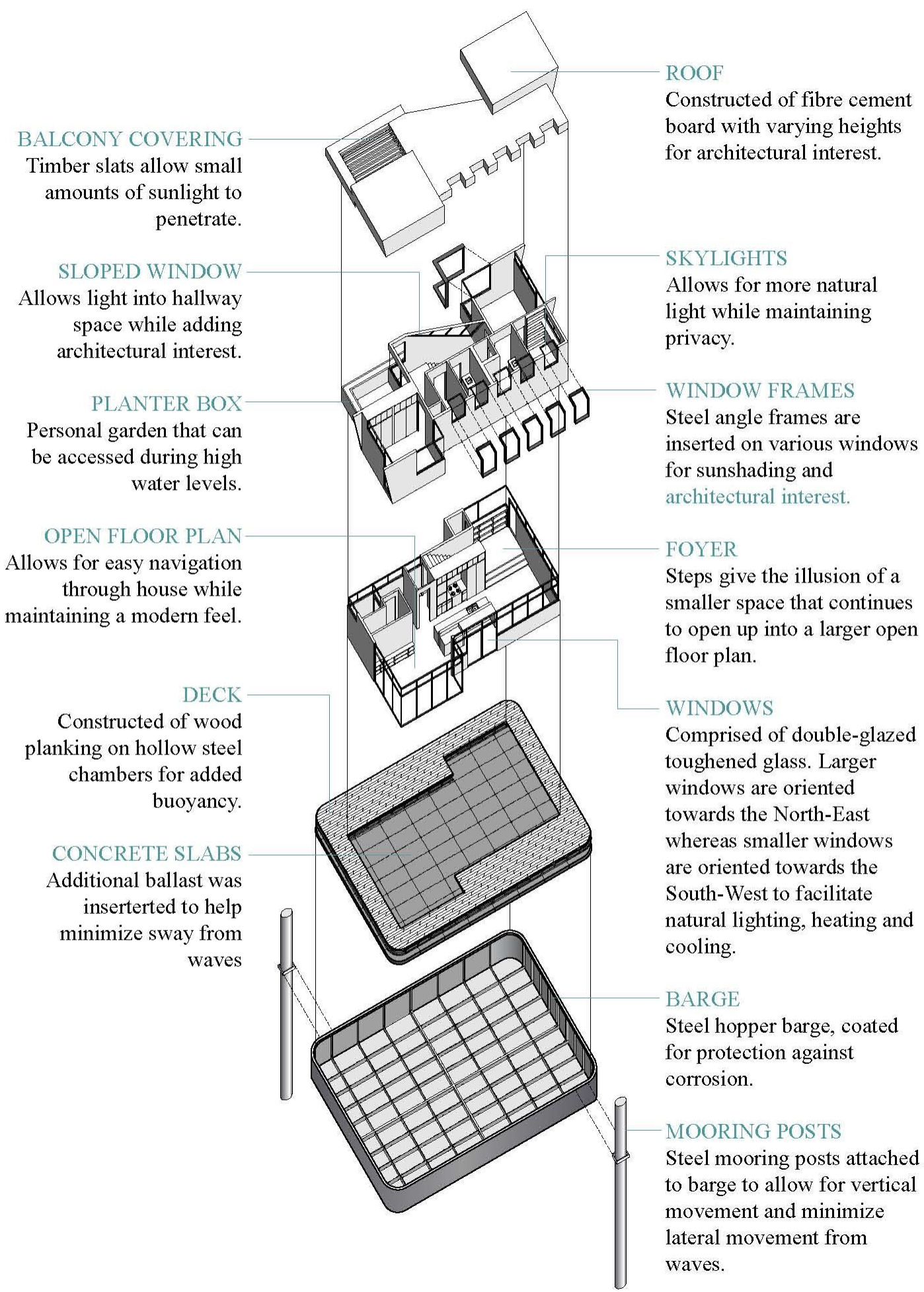

Figure 50 : Exploded Axonometric Plans 

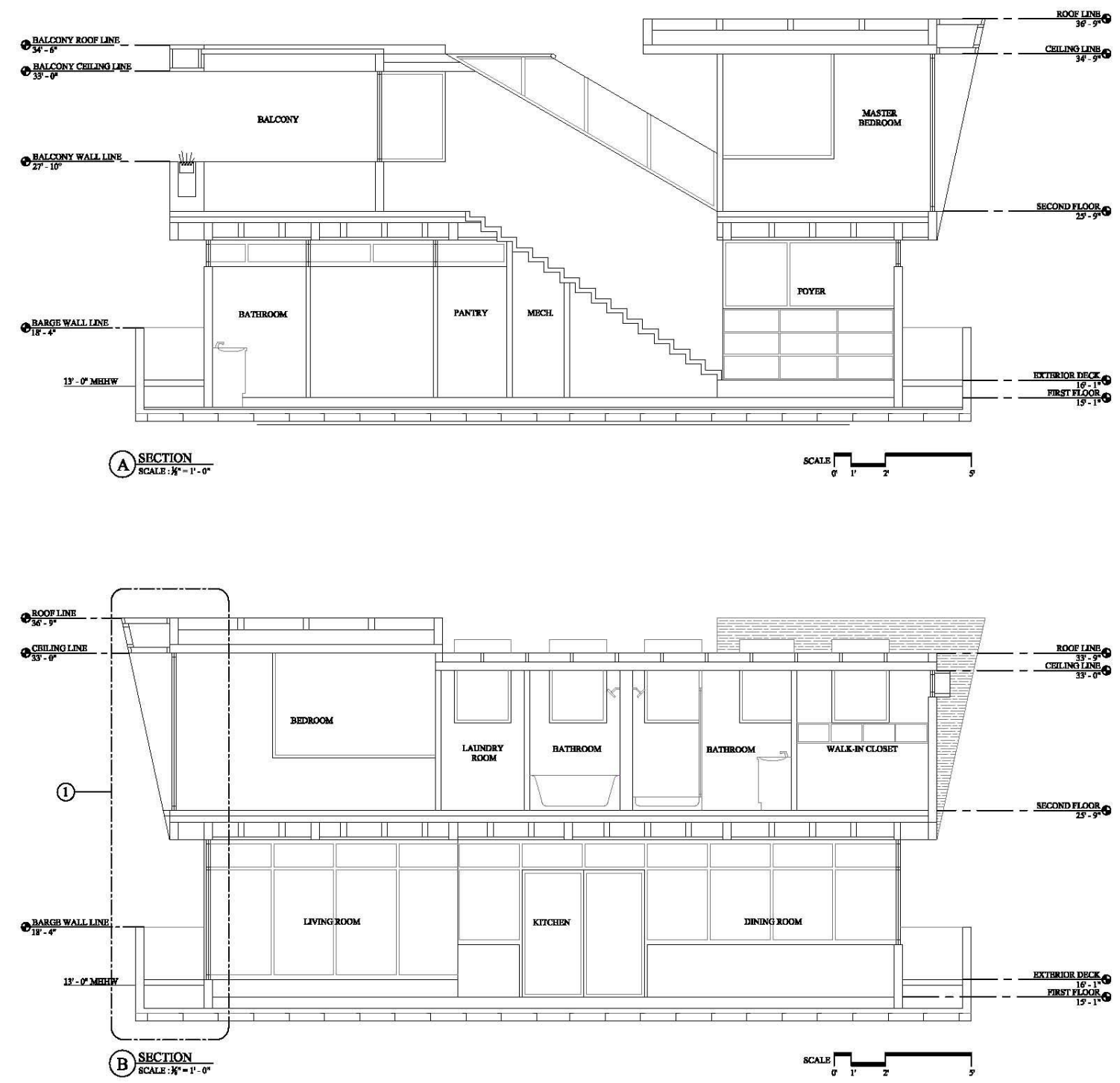

Figure 51 : Sections A \& B 


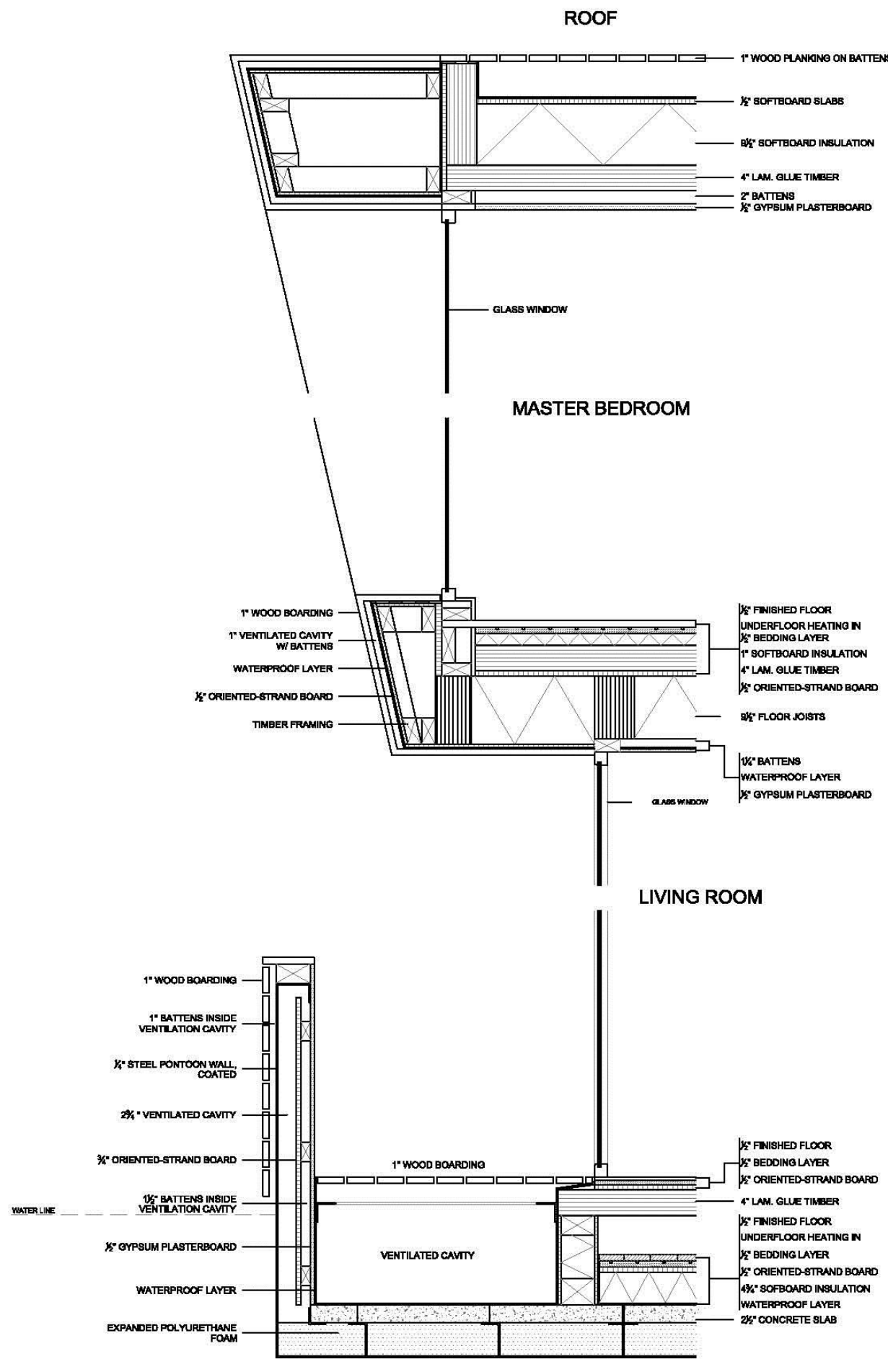

(1) DETAIL - BARGE \& EXTERIOR WINDOW

Figure 52 : Detail 1

Page 65 


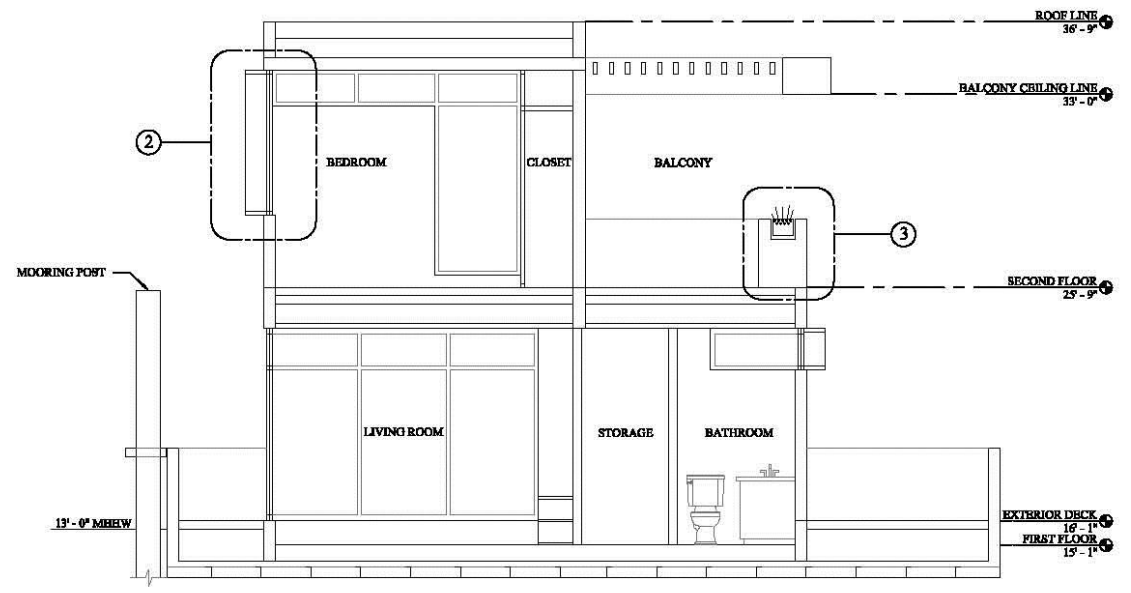

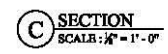
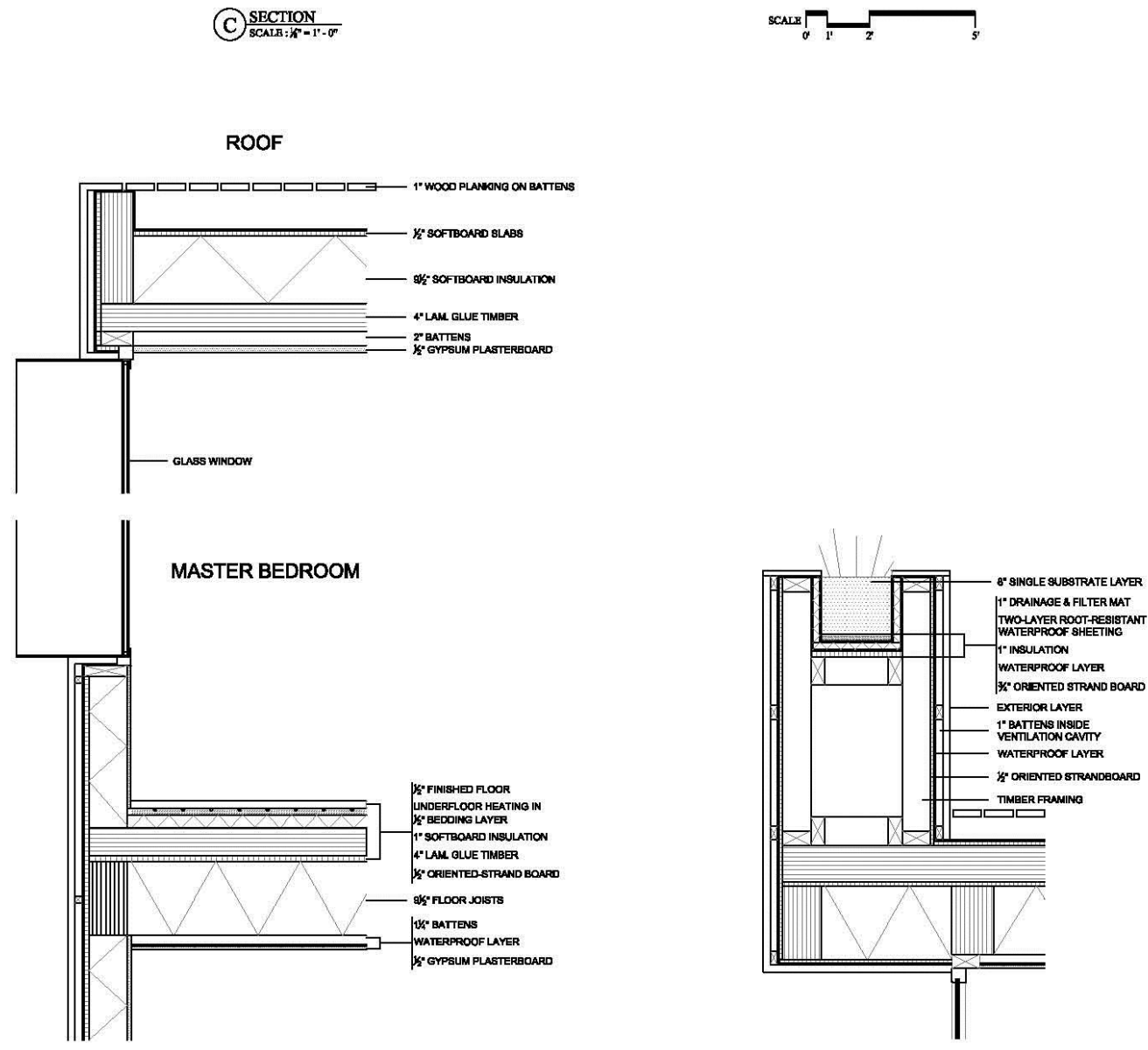

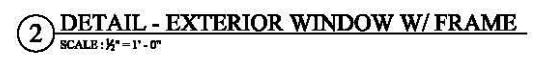

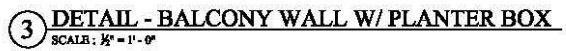

Figure 53 : Section C, Detail $2 \& 3$

Page 66 

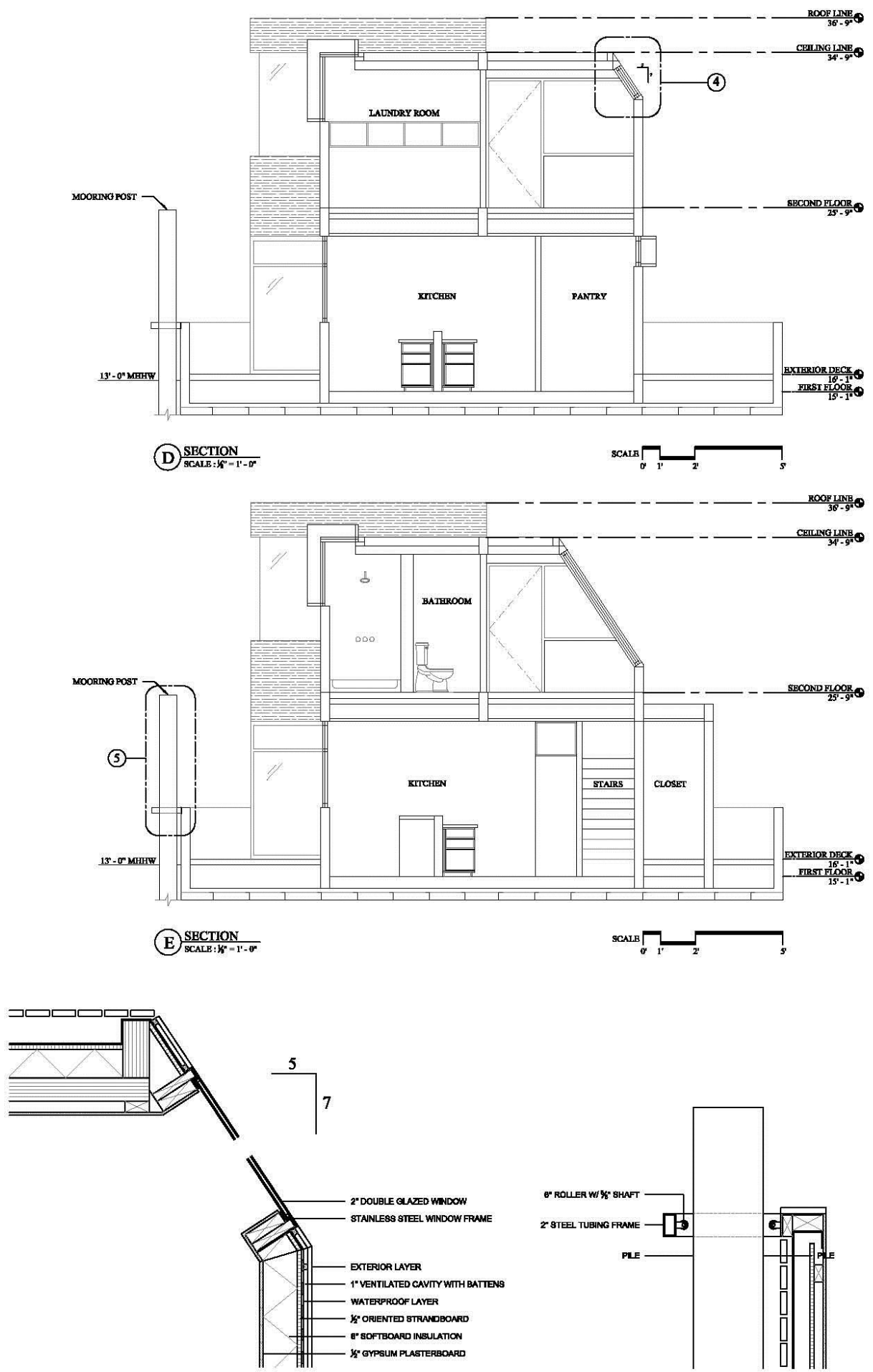

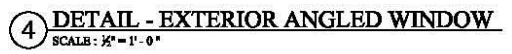

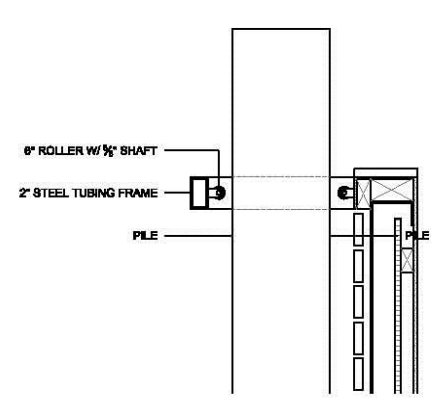

(5) DETAIL - MOORING POST W/STEEL FRAME

Figure 54 : Section D \& E, Detail 4 \& 5 

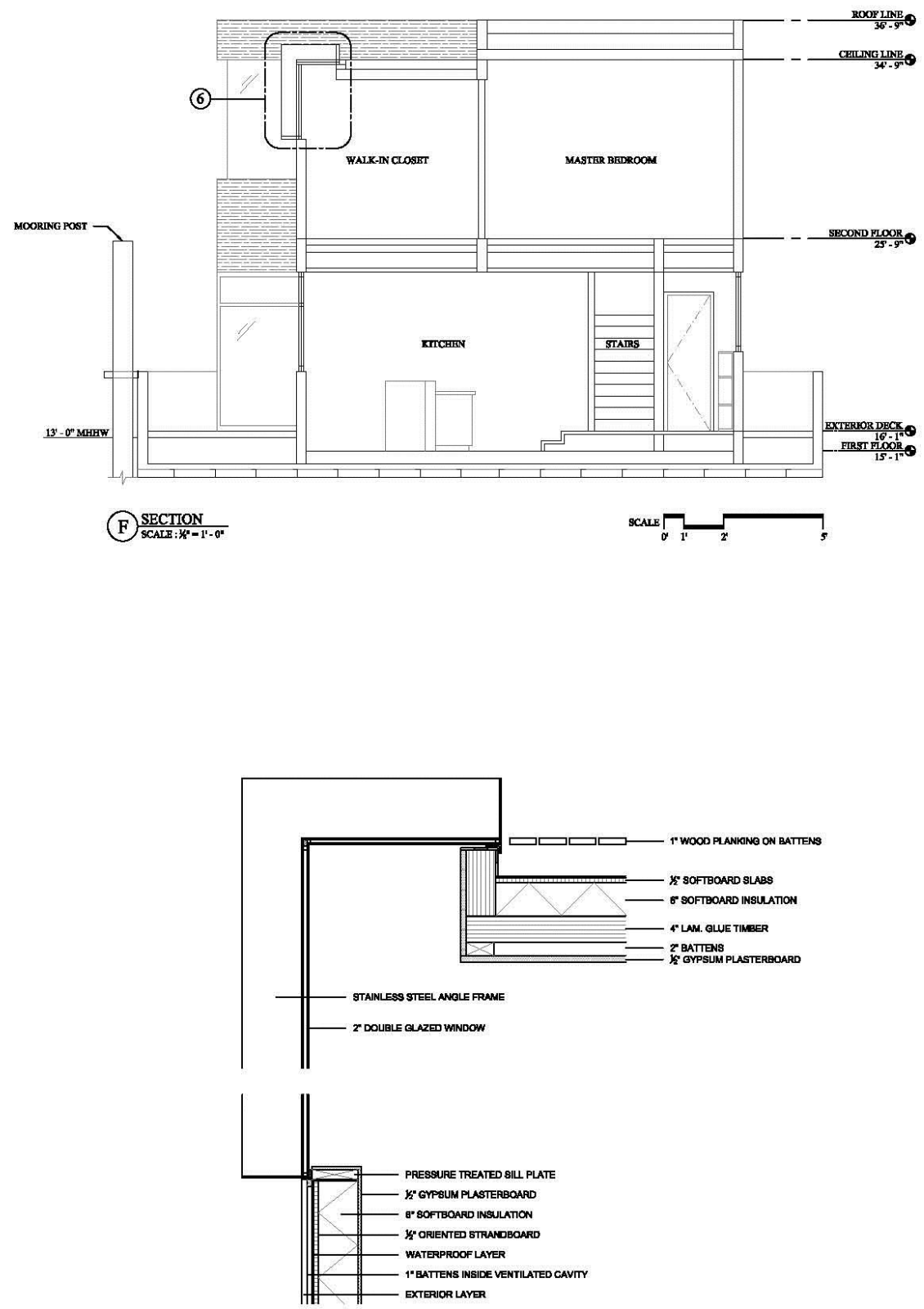

(6) DETAIL - EXTERIOR WINDOW \& SKYLIGHT

Figure 55 : Section F \& Detail 6

Page 68 


\subsection{Concrete Foundation and Piles}

Due to the high liquid limit, low drainage, and slow permeability and runoff of the Novato Clay in the salt ponds, a concrete foundation is used for the houseboat to rest on. The 9 inch thick foundation carves into the levee crest slope approximately 1.5 feet and helps the stability of the house as it rests on land during low tide.

Deep foundations are structural components that transfer loads into deeper layers of earth materials than shallow foundations. Deep foundations, generically referred to as piles, can be driven piles, drilled shafts, micropiles, and grouted-in-place piles. (dot.ca.gov) Engineers are responsible for determining pile type, size, load, depth, etc. Structure design engineers are responsible for calculating the pile design loads and for providing structural details. Geotechnical Services of Materials Engineering and Testing Services and Geotechnical Services is responsible for providing foundation recommendations that include site seismicity, factored downdrag loads, pile tip elevations (based on the factored design loads provided by the structural engineers).

I have determined that Cast-in-steel-shell concrete piles are the most applicable foundation system to this project. Cast-in-steel-shell (CISS) concrete piles are driven pipe piles that are filled with cast-in-place reinforced concrete no deeper than the shell tip elevation. According to Caltrans, "CISS piles provide excellent structural resistance against horizontal loads and are a good option under the following conditions: 1) where poor soil conditions exist, such as soft bay mud deposits or loose sands; 2) if liquefaction or scour potential exist that will cause long unsupported pile lengths; or 3) if large lateral 
soil movements are anticipated." (dot.ca.gov) Due to the bay mud deposits of Novato Clay and high liquefaction potential, I have determined that CISS piles are the appropriate foundation system for this project.

\subsection{Roads and Parking}

A separate parking garage for cars can be constructed for residents on Seaport Blvd. Residents can park their vehicles in the parking garage and take bicycles, motorcycles and golf carts onto the roads on the levee.

The stability berm is 31'-9" wide and can accommodate roads, parking and walkways. For this project, I have designed the levee to have 7'-4" spaces for golf cart parking, a two-way road with a width of 14'-5", and a 10'-0" covered pedestrian walkway. Concrete steps lead residents up from the parking spaces to the entrance ramp and into their homes. (Figure 56)

\subsection{Pedestrian Walkways}

The base of the walkway is made of concrete and its surfaces are aluminum, so not to distract the attention from the water. The selected type of aluminum is low in maintenance and does not become slippery in case of rain, thanks to perforation. These are two advantages over wood, the material that was initially selected for the surfaces. The light reflection in the silver-grey metal gives the walkway an industrial character that goes well with urban water. The aluminum panels are removable so that ground lighting can be installed. 

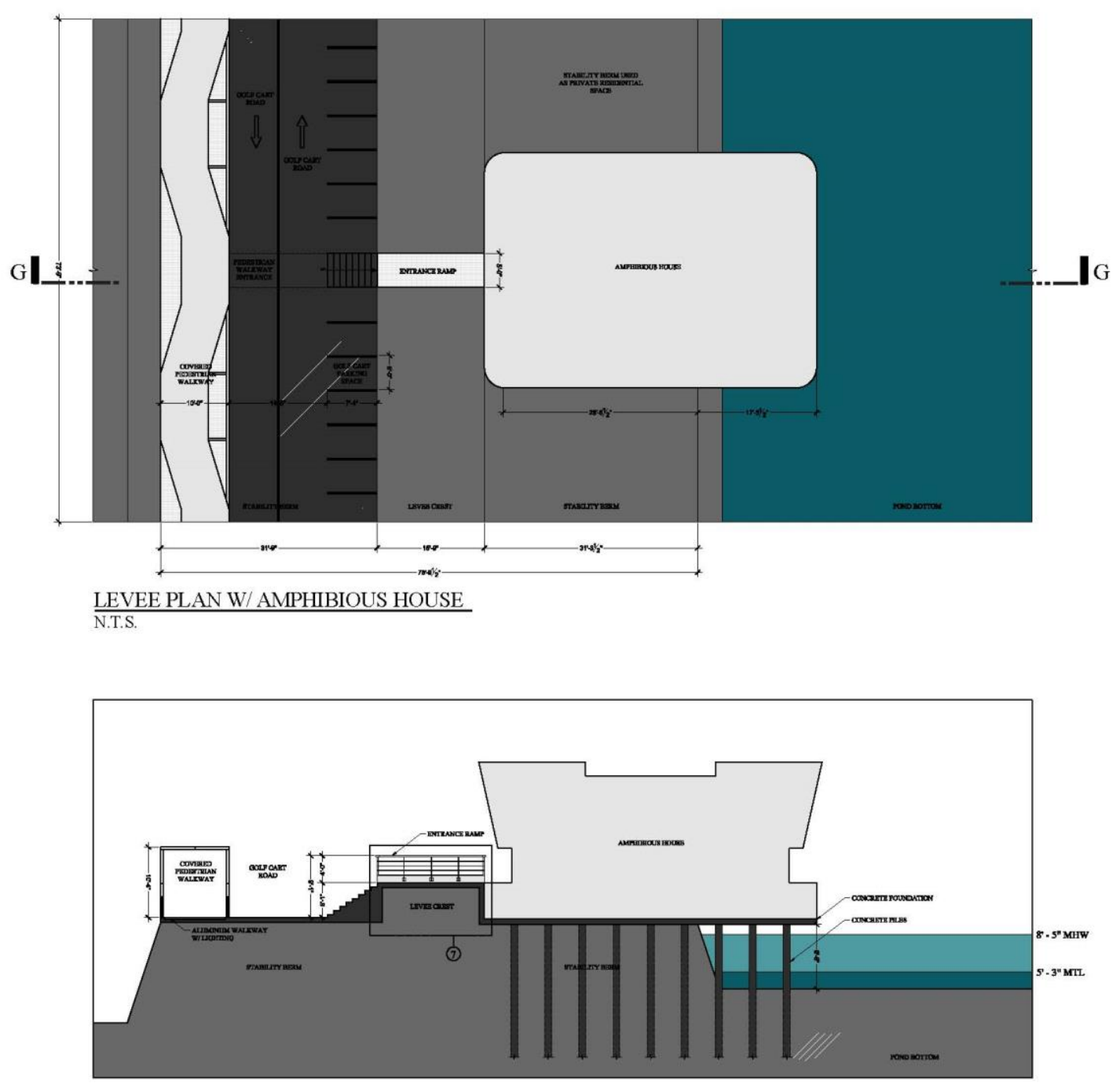

(G) $\frac{\text { SECTION }}{\text { N.T.S. }}$

Figure 56 : Levee Infrastructure \& Section $G$ 


\subsection{Entrance Ramp}

A 15'-9" entrance ramp bridges this gap between the house and the levee and is capable of absorbing fluctuations in the water level. All utilities that could not be put under the surface, like lighting and meter boxes, have been integrated in the entrance ramps. Because the levee is fixed and the house moves up and down with the water level, the cables behind the meter box are umbilical and will vertically stretch as the house moves. (Figure 57)

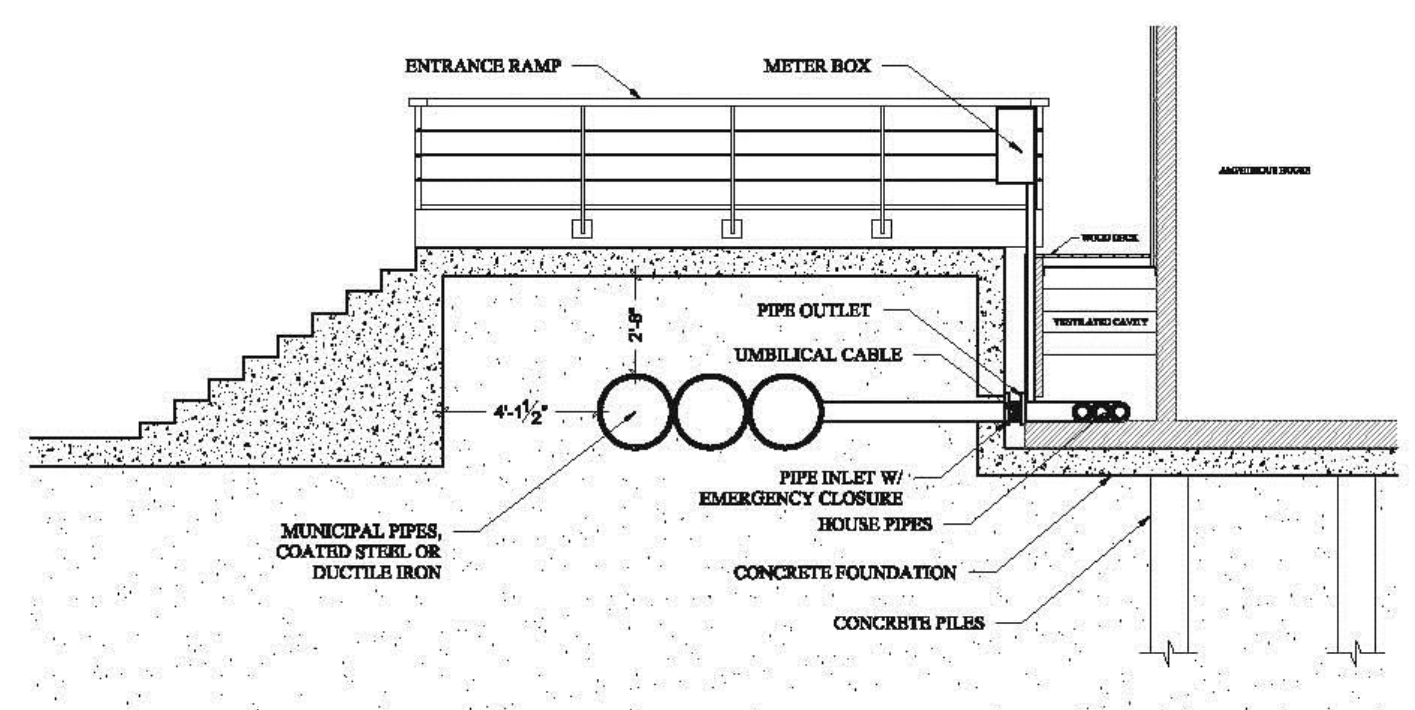

(7) DETAП - LEVEE CABLE \& PIPE SYSTEM

\section{Figure 57 : Detail 7}

\subsection{Cables and Pipes}

The USACE has put in place a set of guidelines for placing pipes inside the levee system. This project follows these guidelines for placing pipes inside the levee and can been seen in Figure 62. The guidelines are as follows: 
1. The backfill should provide a minimum of 1 foot of coverage above the top of the pipe on a levee slopes and at least 2 feet on a levee crest, and should consist of compacted impervious material on a levee crest and riverside slope. Random material can be used on the landside slope if the soil will support grass growth.

2. The pipe should not be buried more than 1 foot in a levee embankment on the riverside slope.

3. Pipes passing over or within the freeboard zone of a levee should be limited to metal pipes, preferably ductile iron or coated steel, suitable for use with flexible couplings. Pipes within the freeboard zone should have provisions for closure on the waterside of the levee accessible from the levee crest.

\subsection{Fire Security}

At a width of 10 feet, the walkways is wide enough for advancing fire fighters and people fleeing in the opposite direction and follows the rules of fire security. The fire brigade is able to access the levee by car and then proceed onto the ramps by foot with their extinguishing gear and safety equipment. However, a fire hose may be too short to reach all the residences in the community. Therefore, a dry hose runs underneath the levees, adjacent to all other cables and pipes of the utility services. In case of fire, the fire brigade places a pump wagon on the mainland in order to fill the dry hose with water. Each residence will have a point where a fire hose can be connected.

\subsection{Underwater Maintenance}

The bottom of the pond is made up of bay mud and therefore can accumulate sludge. Bay mud is comprised of thick deposits of soft, unconsolidated silty clay, which 
is saturated with water. With one or two centimeters per year, a thick layer of sludge will build up and can potentially damage utility connections to the building and corrode the steel barge. Therefore the house rests on a concrete foundation that is built into the lower stability berm on the levee. The berm has an elevation of approximately 15 feet, allowing the house to rest on the levee for the majority of the time. If this is not the case, the house has the potential to get stuck in the mud when the water is low.

\subsection{Floating Calculations}

The principle of floating buildings is based on Archimedes' Law. It states that, "any mass completely or partially submerged in a fluid (gas or liquid) at rest is acted upon by an upward, or buoyant, force the magnitude of which is equal to the weight of the fluid displaced by the body. The volume of displaced fluid is equivalent to the volume of an object fully immersed in a fluid or to that fraction of the volume below the surface for an object partially submerged in a liquid. The weight of the displaced portion of the fluid is equivalent to the magnitude of the buoyant force. The buoyant force on a body floating in a liquid or gas is also equivalent in magnitude to the weight of the floating object and is opposite in direction; the object neither rises nor sinks. If the weight of an object is less than that of the displaced fluid, the object rises. An object heavier than the amount of the fluid it displaces, though it sinks when released, has an apparent weight loss equal to the weight of the fluid displaced." (Britannica.com)

Practically seen, the Archimedes principle allows the volume of an object to be measured by measuring the volume of the liquid it displaces after submerging, and the buoyancy of an object immersed into a liquid to be calculated. 
For any immersed object, the volume of the submerged portion equals the volume of fluid it displaces. E.g., by submerging in water half of a sealed 1-liter container, we displace a half-liter volume of fluid, regardless of the container's contents. If we fully submerge the same container, we then displace one liter of liquid that equals exactly to the volume of the 1-liter container.

An empty 1-litre plastic bottle released in the air will fall down due to the gravitational force of Earth acting on it. If the same bottle is released under water, the same gravitational force acts on it, but it will be pushed upwards towards the surface of the water. The extra force that pushes the bottle upwards comes from the upthrust or Archimedes force. The basic equation for Archimedes force is as follows:

$$
\mathrm{U}=\mathrm{G} /(\mathrm{A} \times \mathrm{P})
$$

Where:

$\mathrm{U} \quad$ is the vertical drop below the water line (m)

$\mathrm{G} \quad$ is the dead load of the total building construction $(\mathrm{kN})$

A is the area of the floating body $\left(\mathrm{m}^{2}\right)$

$\mathrm{P} \quad$ is the density of water $\left(\mathrm{kN} / \mathrm{m}^{3}\right)$

\subsubsection{Determining Dead Load}

According to ASCE, dead loads shall include self-weight of all items of permanent nature that will act continuously throughout the service life of the building. ASCE provides material load values in terms of pounds per square foot $\left(\mathrm{lb} / \mathrm{ft}^{2}\right)$ and pounds per cubic foot $\left(\mathrm{lb} / \mathrm{ft}^{3}\right)$, depending on the material. Most of the values are given in pounds per square foot because the depth value of the material is included in the load whereas certain values are given in terms of pounds per cubic foot in order to accommodate varying thicknesses of materials. 
The weight of the materials can be calculated by multiplying the amount of area $\left(\mathrm{ft}^{2}\right)$ that each material comprises and by the material load $\left(\mathrm{lb} / \mathrm{ft}^{2}\right)$. For example, the wood planking has an area of $780 \mathrm{ft}^{2}$ and a load of $3.2 \mathrm{lb} / \mathrm{ft}^{2}$, therefore it has a total weight of 2,496 lbs contributing to the structure. Other materials with a higher density can be calculated by multiplying the material volume $\left(\mathrm{ft}^{3}\right)$ with the material density $\left(\mathrm{lb} / \mathrm{ft}^{3}\right)$. For example, the steel pontoon wall has a volume of $51.5 \mathrm{ft}^{3}$ and a density of $492 \mathrm{lb} / \mathrm{ft}^{3}$, therefore it has a total weight of 25,338 lbs. Load and density values can be found in Table $4 \& 5$.

Table 4 : Load value of Materials

\begin{tabular}{|c|c|c|c|}
\hline MATERIAL & $\begin{array}{c}\text { AREA } \\
\text { (square feet) }\end{array}$ & $\begin{array}{l}\text { LOAD } \\
\left(\mathrm{lb} / \mathrm{ft}^{2}\right)\end{array}$ & $\begin{array}{l}\text { WEIGHT } \\
\text { (pounds) }\end{array}$ \\
\hline 1" Wood Planking & $780 \mathrm{ft}^{2}$ & $3.2 \mathrm{lb} / \mathrm{ft}^{2}$ & $2,496 \mathrm{lbs}$ \\
\hline 4" Lam glue timber@16" OC & $1808 \mathrm{ft}^{2}$ & $1.5 \mathrm{lb} / \mathrm{ft}^{2}$ & $2,712 \mathrm{lbs}$ \\
\hline $1 \frac{1}{2}$ " Ceiling Battens & $920 \mathrm{ft}^{2}$ & $.35 \mathrm{lb} / \mathrm{ft}^{2}$ & $322 \mathrm{lbs}$ \\
\hline 1" Exterior Battens & $1160 \mathrm{ft}^{2}$ & $1.41 \mathrm{lb} / \mathrm{ft}^{2}$ & $1,635.6 \mathrm{lbs}$ \\
\hline $1 / 2 "$ Gypsum Plasterboard & $2500 \mathrm{ft}^{2}$ & $2.2 \mathrm{lb} / \mathrm{ft}^{2}$ & $5,500 \mathrm{lbs}$ \\
\hline $1 / 2 "$ Finished Floor & $1795 \mathrm{ft}^{2}$ & $4 \mathrm{lb} / \mathrm{ft}^{2}$ & $7,180 \mathrm{lbs}$ \\
\hline $1 / 2 "$ Subfloor & $1795 \mathrm{ft}^{2}$ & $3 \mathrm{lb} / \mathrm{ft}^{2}$ & $5,385 \mathrm{lbs}$ \\
\hline 91/2" Floor Joists @ 16" OC & $1700 \mathrm{ft}^{2}$ & $6 \mathrm{lb} / \mathrm{ft}^{2}$ & $10,200 \mathrm{lbs}$ \\
\hline 4 1/2" Floor Joists @ 16" OC & $875 \mathrm{ft}^{2}$ & $5 \mathrm{lb} / \mathrm{ft}^{2}$ & $4,375 \mathrm{lbs}$ \\
\hline 2x6 Wood Framing@16" OC & $304 \mathrm{ft}^{2}$ & $1.7 \mathrm{lb} / \mathrm{ft}^{2}$ & $516 \mathrm{lbs}$ \\
\hline 2x4 Wood Framing@16" OC & $179 \mathrm{ft}^{2}$ & $1.1 \mathrm{lb} / \mathrm{ft}^{2}$ & $196.9 \mathrm{lbs}$ \\
\hline 1/4" Waterproof Layer & $6109 \mathrm{ft}^{2}$ & $.7 \mathrm{lb} / \mathrm{ft}^{2}$ & $4,276.3 \mathrm{lbs}$ \\
\hline
\end{tabular}

Table 5 : Density Values of Materials

\begin{tabular}{|c|c|c|c|}
\hline MATERIAL & $\begin{array}{l}\text { VOLUME } \\
\text { (cubic feet) }\end{array}$ & $\begin{array}{c}\text { DENSITY } \\
\left(\mathrm{lb} / \mathrm{ft}^{3}\right)\end{array}$ & $\begin{array}{l}\text { WEIGHT } \\
\text { (pounds) }\end{array}$ \\
\hline 9.5" Soft Board Insulation & $1286.5 \mathrm{ft}^{3}$ & $1.8 \mathrm{lb} / \mathrm{ft}^{3}$ & $2,315.7 \mathrm{lbs}$ \\
\hline 6" Soft Board Insulation & $1369 \mathrm{ft}^{3}$ & $1.8 \mathrm{lb} / \mathrm{ft}^{3}$ & $2,464.2 \mathrm{lbs}$ \\
\hline 4.5" Soft Board Insulation & $328 \mathrm{ft}^{3}$ & $1.8 \mathrm{lb} / \mathrm{ft}^{3}$ & $590.4 \mathrm{lbs}$ \\
\hline 1" Soft Board Insulation & $62.5 \mathrm{ft}^{3}$ & $1.8 \mathrm{lb} / \mathrm{ft}^{3}$ & $112.5 \mathrm{lbs}$ \\
\hline Oriented Strand Board & $248 \mathrm{ft}^{3}$ & $45 \mathrm{lb} / \mathrm{ft}^{3}$ & $11,160 \mathrm{lbs}$ \\
\hline Concrete Slab & $265 \mathrm{ft}^{3}$ & $105 \mathrm{lb} / \mathrm{ft}^{3}$ & $27,825 \mathrm{lbs}$ \\
\hline Expanded Polyeurethane Foam & $1060 \mathrm{ft}^{3}$ & $1 \mathrm{lb} / \mathrm{ft}^{3}$ & $1,060 \mathrm{lbs}$ \\
\hline Windows and Frames & $153.2 \mathrm{ft}^{3}$ & $160 \mathrm{lb} / \mathrm{ft}^{3}$ & $24,512 \mathrm{lbs}$ \\
\hline Steel Pontoon & $51.5 \mathrm{ft}^{3}$ & $492 \mathrm{lb} / \mathrm{ft}^{3}$ & $25,338 \mathrm{lbs}$ \\
\hline
\end{tabular}


After adding up the total amount of weight, the building has a total weight of 140,172.6 lbs. The weight value is then converted to kilonewtons for the purpose of this equation. The total dead load is $623.52 \mathrm{kN}$.

\subsubsection{Determining Live Load}

According to ASCE 7, a live load is a load produced by the use and occupancy of the building or other structure that does not include construction or environmental loads, such as wind load, snow load, rain load, earthquake load, flood load, or dead load. Minimum uniformly distributed live load for residential dwellings is averaged at $40 \mathrm{lb} / \mathrm{ft}^{2}$. By multiplying this number by the total square footage of the building $\left(2609 \mathrm{ft}^{2}\right)$, the total weight is $104,360 \mathrm{lbs}$. The weight value is then converted to kilonewtons for the purpose of this equation. The total live load is $464.22 \mathrm{kN}$.

\subsubsection{Determining the Area of the Floating Body}

The area of the building can be calculated by multiplying the length and width of the barge structure. In this instance, the barge has a length of 49 feet and a width of 35 feet and a total area of $1715 \mathrm{ft}^{2}$. This value can be converted to square meters for the purpose of this equation, totaling $159.33 \mathrm{~m}^{2}$. The same method can be done for the second story, totaling an area of $894 \mathrm{ft}^{2}$ or $83 \mathrm{~m}^{2}$. The total area of the building can be found by adding up the both floor areas, totaling $242.33 \mathrm{~m}^{2}$.

\subsubsection{Density of Water}

The density of seawater varies with temperature and salinity of the water. As temperature increases, density decreases. Inversely, as salinity of the water increases, density also increases. Although the density of seawater varies at different points in the 
ocean, NOAA has estimated that the average density of seawater in the San Francisco Bay is $10.06 \mathrm{kN} / \mathrm{m}^{3}$.

\subsubsection{Calculating Buoyancy}

The basic equation for floating construction is as follows:

$$
\mathrm{U}=\mathrm{G} /(\mathrm{A} \times \mathrm{P})
$$

Where:

$\mathrm{U} \quad$ is the vertical drop below the water line (m)

$\mathrm{G}$ is the total load of the total building construction $(623.52 \mathrm{kN}+464.22 \mathrm{kN})$

A is the area of the floating body $\left(242.33 \mathrm{~m}^{2}\right)$

$\mathrm{P} \quad$ is the density of water $\left(10.06 \mathrm{kN} / \mathrm{m}^{3}\right)$

Equation Values:

$\mathrm{U}=1,087.74 \mathrm{kN} /\left(242.33 \mathrm{~m}^{2} \mathrm{x} 10.06 \mathrm{kN} / \mathrm{m}^{3}\right)$

Therefore:

$\mathrm{U}=.45 \mathrm{~m}$

The vertical drop of the building below the water line is approximately .45 meters or 1.5 feet. Based on Archimedes Principle of Buoyancy, the house is capable of carrying a maximum load of $3,715 \mathrm{kN}$ or $835,165 \mathrm{lbs}$.

\subsection{Cost Estimate}

An Eco-Sea Cottage that is 55 feet in length by 16 feet in width and has a total area of 1,470 square feet costs approximately $\$ 349,000$ to purchase or about $\$ 237$ per square foot. The residence included 2 bedrooms, 2 bathrooms, living room and kitchen, an office, 2 porches and an upper sundeck that is built atop a steel barge. Similarly, the project here is about 49 feet in length by 27 feet in width and has a total area of 2,190 
square feet. If the cost to build an amphibious home of comparable size is $\$ 237$ per square foot, then the project here will cost approximately $\$ 520,000$ to purchase, almost $\$ 289,000$ less than the average house price in Redwood City in 2013.

Annual houseboat insurance runs about $0.5 \%$ to $1 \%$ of the replacement value. For this residence, a $\$ 520 \mathrm{~K}$ amphibious house will have to pay $\$ 2,600$ to $\$ 5,200$ per year in insurance.

Although this project is for an amphibious house and not a houseboat, the monthly docking rate in San Francisco is about $\$ 14$ per foot length. The docking includes hookups to water and electricity which are included in the docking fee. For this project, a 49 foot amphibious house will pay approximately \$686 in docking fees. 


\section{Chapter 6 \\ Recommendations for a New Amphibious Community}

The purpose of this section is to establish a set of guidelines that will facilitate the process of constructing multiple amphibious houses that are consistent with the city's building codes and standards. This section is comprised of development standards and design guidelines which set the framework for new development in the salt ponds.

\subsection{Planning}

In the early stages of planning for the amphibious community in the Cargill Salt Ponds, a review of existing conditions must be undertaken, focusing on the opportunities and constraints of the site. The following summarizes the major issues which affect planning for the salt ponds:

USACE. It is estimated that the Army Corps of Engineers (COE) and other agencies will need approximately 10 to 16 months to review plans and applications and issue a permit for the development of the Salt Ponds. Because the acreage of restored wetlands greatly exceeds that required for mitigation of the project's impacts, a high level of cooperation is anticipated from the permitting agencies. (Belmont Slough Development Plan, 9)

Geology and Soils. Issues related to geotechnical considerations involve settlement and stability, particularly slope stability, of levees and building pads. An investigation of existing geologic conditions in the plan area must be conducted prior to preparations for development.

Infrastructure. Future infrastructure capacities, related in particular to sewer, water and traffic, are limited on the salt ponds. Although there are few existing roads and structures on the levees, the U.S. Army Corps of Engineers review the geologic conditions of the levees to determine where it is best to develop infrastructure.

Endangered Species. Due to the high salinity of the ponds, there is little aquatic life to be found and is limited to brine shrimp and brine flies. However, dry areas, levees and internal islands can provide breeding habitat for birds such as the 
Western snowy plover and American Avocet. An investigation of existing wildlife and endangered species must be conducted prior to development in order to minimize any detrimental impacts on local species.

\subsection{Policies}

In 1965, the San Francisco Bay Conservation Development Commission was established and set guidelines for the public coastline of the bay. The plan policies, taken directly from the San Francisco Bay Plan, are as follows:

1. Shore areas not proposed to be reserved for a priority use should be used for any purpose (acceptable to the local government having jurisdiction) that uses the Bay as an asset and in no way affects the Bay adversely. This means any use that does not adversely affect enjoyment of the Bay and its shoreline by residents, employees, and visitors within the site area itself or within adjacent areas of the Bay or shoreline.

2. Accessory structures such as boat docks and portions of a principal structure may extend on piles over the water when such extension is necessary to enable actual use of the water, e.g., for mooring boats, or to use the Bay as an asset in the design of the structure.

3. Wherever waterfront areas are used for housing, whenever feasible, high densities should be encouraged to provide the advantages of waterfront housing to larger numbers of people.

4. Because of the requirements of existing law, the Commission should not allow new houseboat marinas. (Note: A houseboat is a boat fitted for use as a dwelling and may be mobile. An amphibious house is a dwelling with a buoyant base that is capable of vertical movement. Existing policies do not specify the requirements or restrictions for an amphibious house. This policy can only be applied to a houseboat.)

\subsection{Sustainable Construction Practices and Policies}

The San Francisco Bay Conservation and Development Commission listed sustainable construction practices in all construction permits that must be regulated during development and are stated as follows:

1. All construction operations shall be performed to prevent construction materials from falling, washing, or blowing into tidal waters of the Bay. In the event that 
such material escapes or is placed in an area subject to tidal action of the Bay, the developer shall immediately retrieve and remove such material at their expense. The developer shall also employ best management practices, such as compaction, soil fences, jute matting, etc., to assure that excavated or stockpiled material will not erode after placement.

2. The work shall be performed in a manner that will prevent, avoid, or minimize to the extent possible any significant adverse impact on any tidal marsh, other sensitive wetland resources, and existing native upland vegetation. The developer shall employ mitigation measures to minimize impacts to wetland areas

3. All construction debris and any uncovered excavated material shall be removed from the project site for proper disposal. Some excavated material may be used as fill material as portions of the site are reconfigured to support a variety of wetlands habitats. Any equipment or vehicles driven and/or operated within or adjacent to the site shall be cleaned of all external oil, grease, and materials that, if introduced to water, could be deleterious to aquatic life or wildlife habitat. Stationary equipment such as motors, pumps, generators, and welders, located within or adjacent to any existing or proposed tidal wetlands shall be positioned over drip pans.

\subsection{Regulatory Requirements}

The following is a summary listing of permits and approvals that will be necessary in order to implement the development of a community within the Cargill Salt Ponds:

General Plan Amendment. With the adoption of the Preserve at Redwood Shores Precise Plan, the General Plan text and land use diagram must be amended to ensure consistency between the two documents.

CEQA. The California Environmental Quality Act (CEQA) requires the preparation and certification of an Environmental Impact Report (EIR) for the Precise Plan.

Planned Community (PC) Permits. Development within the Precise Plan area shall be approved by a PC Permit issued in accordance with Article 52 of the Redwood City Zoning Ordinance. This PC Permit may cover the entire plan area, or only a portion.

Parcel Map and Rough Grading Plan. Following adoption of the plan, a parcel map and rough grading plan will create overall residential, public space and school parcels and establish rough grades for the site. 
COE Permit. The Clean Water Act and Endangered Species Act require review by the Army Corps of Engineers (COE) and other agencies including the US Fish and Wildlife Service for any site that impacts existing wetlands, historic navigable waters or endangered species habitat.

SFRWQCB Permit. The Porter-Cologne Act requires review by the San Francisco Bay Regional Water Quality Control Board (SFRWQCB) for any site that impacts existing wetlands and other waters of the State.

BCDC Approval. The Bay Conservation and Development Commission (BCDC) must issue a permit for all work within 100 feet of the San Francisco Bay shoreline.

RSOA Architectural Review. The New Construction Committee (NCC) of the Redwood Shores Owners' Association (RSOA) must review and approve each proposed building project in Redwood Shores. This review process takes place in five stages:

1. Briefing Sessions. Identify and discuss planning and design concepts for the project, architectural design criteria, and site planning constraints.

2. Concept Design Review. Presentation and approval of concepts of design such as siting, massing, character,

3. Preliminary Design Review. Review of the building project design in significant detail prior to the commencement of working drawings.

4. Construction Document Review. Confirm that construction documents conform to Stage 3 approval and review additional details.

5. Construction Period and Project Completion Review. On-going periodic review of the construction of the project to monitor conformity of construction to the approved construction documents.

Architectural Review Committee. The City of Redwood City will also perform an architectural review of the proposed residences.

\subsection{Determining Land Use}

The permitted land uses fall into three general categories defined by the 1990

Redwood City Strategic General Plan and must include:

Open Space: Any parcel or area of land or water which is essentially unimproved and is devoted to the preservation of natural resources, the managed production of resources, outdoor recreation, or public health and safety. 
Public: Areas devoted to public or quasi-public use such as government office buildings, schools, hospitals, and corporate yards.

Residential: Land to be developed with single story to three-story amphibious residential structures.

A master developer will work with the City and Regional Planning Department to determine the size and location of the land uses. Although the land must be reserved for open space, public space and residential development, this section will continue to focus solely on the residential development.

\subsection{Design}

Each residence will work with an architect to design a home that fits the individual needs of the residents. The architect will determine the size of the home, the number of rooms, the materials used, etc. An engineer must be involved in order to determine the distribution of load within the residence as well as specify the size of the foundation to ensure its buoyancy. The architect will then work with the master developer to designate plot size and layouts for each residence.

\subsection{Construction and Financing}

The Salt Ponds residences will be constructed and financed by the master developer. Public improvement will be funded by the master developer through the General Improvement District (GID). The GID, established in 1964, assesses a fee to the construction of each new home in the development in an amount determined by the cost of related public improvements. This ensures that all public improvements will be funded

entirely by the construction and sale of new townhomes. In addition, the master 
developer shall ensure that capital improvements and infrastructure needed for development are in place prior to development.

\subsection{Re-purposing the Levees}

Although the levees surrounding the Cargill Salt Ponds were described as "substandard levees" in a shoreline study by the United States Army Corps of Engineers (USACE), I propose a series of steps to repurpose the existing levees as a roadway system and use the area within the levees as an amphibious community development. The steps to repurpose the levees include (1) introducing tidal influence to the ponds through levee breaches after water quality control measures are deemed safe by the San Francisco Bay Regional Water Quality Control Board, (2) establish an adequate depth of dredging that will accommodate water flow, and (3) use the extra sediment to improve the inland levees and establish parking and roadways for the residents. The master developer will utilize the larger bayside levees to develop the necessary infrastructure to accommodate an amphibious community. At a width of 30 feet, each stability berm will offer ample space for parking, roadways and pedestrian paths. These steps will help maintain the wetlands habitat for existing wildlife while allowing integration of a community. 


\section{Chapter 7}

\section{Conclusions}

When looking at how we manage water and design in its close proximity, the immense scale of the challenge of flooding that we are now facing becomes clear. Climate change, and its many effects - including increasing sea levels, more severe precipitation and increased flood risk - is already being felt, however its true effects will be measured in decades. This is the timeframe within which planning, design and development should operate. The buildings and places that we create in the next ten years will form the backbone of an amphibious lifestyle for the next few decades and beyond. In order to prepare for the future, designers and builders must not look at the limitations of water, but at the opportunities it presents.

Amphibious buildings are a proven, low-cost, low-impact flood protection strategy that gives a community enhanced flood resilience and improves its ability to recover from disaster. When flooding occurs, the water dwelling vertically rises with the water levels to remain safely above water then settles back into place as the water recedes. Successful amphibious foundation systems are functioning in the Netherlands, Louisiana and Sausalito, among others, where they provide flood protection that is both more reliable and more convenient than can be obtained from permanent static elevation.

This project has improved on existing amphibious residences of the past and generated a successful prototype amphibious house. The steel barge foundation will prove success in both durability and as a floating foundation in salt water. Unlike the 
precedent studies, added concrete slab on top of the steel barge will help improve ballast in the foundation. Systems such as underfloor heating and the specific arrangement of windows will help facilitate the residents in times of changing climates. Like the precedent studies, the residence is built symmetrically to ensure the foundation remains even, however the contemporary façade and interior of the residence are built to accommodate the vernacular of Redwood City. By building the residence within the existing levee system, wave action is minimized. The series of stability crests and berms are also capable of carrying municipal pipes and cables, thus ensuring the residents that an amphibious house will have the same amenities as a house built on land. Comfort is guaranteed because all buildings will have the same facilities as a building on land, including heating, cooling and ventilation. Quality of the building is not compromised because the official building requirements for floating buildings are the same as on land.

The increased attractiveness of living on the water after centuries of dreading inundation indicates that the population feels that rising water levels are not to be feared, but to be embraced. Open water adds variation to a landscape and invokes feelings of tranquility and space, along with attractive views. Amphibious buildings are similar to those on land. Although construction techniques vary, only the foundations are essentially different from their equivalents on land. In terms of cost, buoyant foundations are similar to filled-in land or foundation piles. Building on water is financially feasible at locations where land is expensive and where there is little or no alternative space on land. 
The patterns of development are being set now. Planning, design and construction has not evolved sufficiently to face a future of increased flood risk with confidence. However, as we have seen from the precedent studies, new alternative thinking and innovation is coming to the forefront. The long-term view that is necessary in taking account of climate change also enables us to view other issues with the same horizon of opportunity - facilitating new solutions to spatial planning and the location of settlements, best practice in building design, infrastructure development, and environmental flood defense.

It is time to evolve a new relationship with water, to ask what is possible of design and construction, and begin to look towards a flooded future with confidence and imagination. 


\section{BIBLIOGRAPHY}

Archimedes Principle. Encyclopedia Britannica, 2014. Web. 21 Jan, 2014. $<$ http://Britannica.com/>.

BCDC Living with Water. San Francisco Bay Conservation and Development Commission, Oct. 2011. Web. 21 Jan. 2014.

California Legislature. Cargill Salt Ponds Hearings. Sacramento: Senate Publications, 2002. Print.

Cheng, R. T., and Gartner, J. W. Harmonic Analysis of Tides and Tidal Currents in South San Francisco Bay. Estuarine, Coastal, and Shelf Science. 1985. Web. 24 Mar. 2013.

Climate Action Plan for San Francisco. San Francisco Department of the Environment, Sep. 2004. Web. 14 Aug. 2013.

Deep Foundations. Department of Transportation, Dec. 2000. Web. 2 Feb. 2013.

English, Elizabeth. Amphibious Foundations and the Buoyant Foundation Project: Innovative Strategies for Flood-Resilient Housing. Ontario: University of Waterloo School of Architecture. 2010. Print.

Floating Houses Ijburg. Architectenbureau Marlies Rohmer, n.d.. Web. 23 Nov. 2013. $<$ http://rohmer.nl/>

Grossi, Patricia, \& Robert Muir-Wood. Flood Risk in New Orleans. Risk Management Solutions. 2006. Web. 2 Feb. 2013.

Metz, Tracy. "Rebuilding After Katrina.” Architecural Record 194.6 (2006): 140-142. Print.

Meyer, Han, \& Dale Morris \& David Waggonner. "Dutch Dialogues." SUN 13 Apr. 2009: Print. 13.

Morphopedia. Morphosis Architects, Inc., 2014. Web. 2 Feb 2014.

National Flood Insurance Program. FEMA, n.d.. Web. 14 Aug. 2013. $<$ http://fema.gov/>.

Nillesen, Anne, \& Jeroen Singelenberg. Waterwonen in Nederland. Rotterdam : NAi Uitgevers/Publishers, 2011. Print.

Oosthoek, K. Dutch River Defenses in Historical Perspective. Environmental History Resource, Web. 24 Mar. 2013. 
Patton, Cynthia. Turning Salt Into Environmental Gold: Wetland Restoration in the South San Francisco Bay Salt Ponds. Oakland: Save San Francisco Bay Association, 2002. Print.

Pile Installation Demonstration Project. San Francisco-Oakland Bay Bridge. East Span Seismic Safety Project. California Department of Transportation, Jun. 1999. Web. 12 Oct. 2013. <http://dot.ca.gov/>.

Prosun, Prithula. The LIFT House. Ontario: University of Waterloo, 2011. Print.

Shaffer, Kathy. Houseboats: Aquatic Architecture of Sausalito. Pennsylvania: Schiffer Publishing Ltd., 2007. Print.

Redwood City General Plan. City of Redwood City, 11 Oct. 2010. Web. 14 Aug. 2013.

Royal Institute of British Architects. Living With Water: Visions of a Flooded Future. London: RIBA, 2007. Print.

Van der Pol, Johan. Flood Proof Architecture. Climate of Coastal Cooperation. Netherlands: Coastal and Marine Union, 2011. Print. 